\author{
UNIVERSITY OF SÃO PAULO \\ SÃO CARLOS SCHOOL OF ENGINEERING
}

DANIELA VANESSA RODRIGUEZ LARA

\title{
Community severance and vertical equity assessment with spatially aggregated data
}



UNIVERSITY OF SÃO PAULO

SÃO CARLOS SCHOOL OF ENGINEERING

DANIELA VANESSA RODRIGUEZ LARA

\section{Community severance and vertical equity assessment with spatially aggregated data}

\footnotetext{
Programa de Pós-graduação em
Engenharia de Transportes da EESC-USP
Exemplar definitivo (corrigido). O exemplar
original está disponível na CPG da EESC-USP
São Carlos, 06/08/2019
RESOLução CoPGr N 6018, DE 13 DE OUTUBRO DE 2011, artigo 50
}

Master's Thesis presented to the São Carlos School of Engineering at the University of São Paulo, as part of the requirements for obtaining the degree of Master of Science, Graduate Program in Transportation Engineering.

Area: Planning and Operations of Transport Systems

Supervisor: Professor Titular Antônio Nélson Rodrigues da Silva

São Carlos 
I AUTHORIZE THE TOTAL OR PARTIAL REPRODUCTION OF THIS WORK, THROUGH ANY CONVENTIONAL OR ELETRONIC MEANS, FOR STUDY AND RESEARCH PURPOSES, SINCE THE SOURCE IS CITED.

Catalog card prepared by Patron Service at "Prof. Dr. Sergio Rodrigues Fontes" Library at EESC/USP.

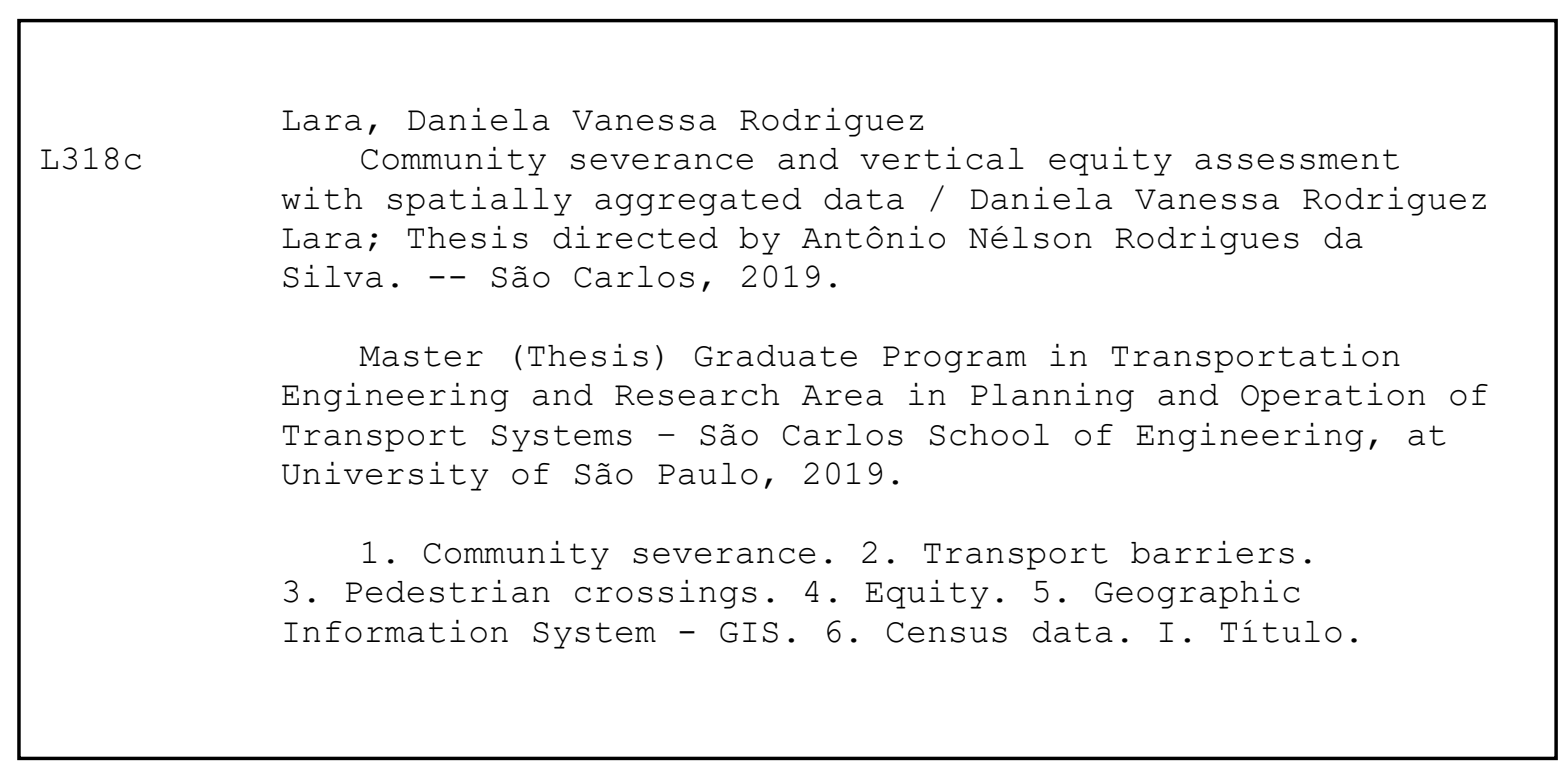

Elena Luzia Palloni Gonçalves - CRB 8/4464 


\section{FOLHA DE JULGAMENTO}

Candidata: Engenheira DANIELA VANESSA RODRIGUEZ LARA.

Título da dissertação: "Avaliação do efeito barreira e da equidade vertical por meio de dados agregados espacialmente".

Data da defesa: 02/07/2019.

Comissão Julgadora:

Resultado:

Prof. Titular Antonio Nelson Rodrigues da Silva (Orientador)

APROUADA

(Escola de Engenharia de São Carlos/EESC)

Prof. Dr. Rui António Rodrigues Ramos

APROUDDA

(Universidade do Minho)

Prof. Dr. Paul Christian Pfaffenbichler

APROUADA

(Universität für Bodenkultur Wien/Boku)

Coordenadora do Programa de Pós-Graduação em Engenharia de Transportes:

Profa. Associada Ana Paula Camargo Larocca

Presidente da Comissão de Pós-Graduação:

Prof. Titular Murilo Araujo Romero 

I dedicate this dissertation to my beloved parents and sisters who have always supported me in everything. 

First of all, I would like to thank my beloved parents, Amparo Del Carmen Lara de Rodriguez and Mario Rodriguez Bustamante, for their unconditional support. They are wonderful parents, who have always taught me to be an independent, determined and diligent person. I thank them for my upbringing, education, their patience, their teachings and the incentives that they have given me throughout all these years. Without them I would not be where I am today.

I would also like to thank my dear sisters, Mariela Sisoka Rodriguez Lara and Gabriela Lara Rodriguez, for their patience, affection and understanding. They made my comings and goings between São Carlos and São Bernardo do Campo (workplace and home) more fun, joyful and light, recomposing my energy when returning to São Carlos and writing this thesis. These beautiful and captivating women inspire me to follow my goals and believe that, with them, I can change the world.

I gratefully thank my supervisor, Prof. Antônio Nélson Rodrigues da Silva, who besides being an exceptional person, is an excellent supervisor, always helpful, interested, extremely precise and organized, which motivates and inspires me to want to be a better professional. In addition, I am grateful for the opportunity to work on this topic, which has brought me great personal and professional satisfaction.

Finally, I would like to thank my colleagues from the STT for their friendship, for their partnership and for the conversations in the cafe, which have often not only served as a relaxing moment, but also as sources of information and clearing up doubts. 

"You cannot hope to build a better world without improving the individual. To that end every person must work for his own improvement, and at the same time he must share a general responsibility for all humanity (...)"

(Curie, 1922, p.5). 

LARA, D. V. R. (2019). Community severance and vertical equity assessment with spatially aggregated data. Thesis (Master). São Carlos School of Engineering, University of São Paulo, São Carlos, 2019.

Transport related urban barriers are often a consequence of the unplanned expansion of transport infrastructures (railways, freeways, roadways and urban streets), housing growth around those infrastructures, and the vehicular traffic itself. This process, also known as "community severance", is a problem that mainly affects vulnerable social groups (the elderly, young children and the physically disabled), and impairs active trips. For this reason, we propose a simple and low-cost analytical approach for the assessment of community severance based on a classification of the quality of pedestrian crossings on two different types of transport infrastructures, railways and urban streets. Furthermore, the approach identifies possible inequities regarding spatially aggregated demographic data in the surroundings of the distinct classification groups. The method for both transport barriers is similar, however, due to their different characteristics, there are specific procedures for each. In general, the analysis procedures that comprise the method, for both transport infrastructures, include: data collection, characterization of the transport barrier through the evaluation of a set of criteria, classification of the quality of pedestrian crossings, statistical analysis and vertical equity analysis. In addition, we presented two case studies in order to illustrate the method. The case studies comprise a railway and urban streets located in the urban region of the city of São Carlos, which is a medium-sized Brazilian city. Results indicated evidence of association between the variables. In addition, the study showed evidence that the residents nearby the railway and the urban streets that have a low income or are aged up to 19 years old are poorly assisted in relation to pedestrian urban mobility. Hence, even with the limitation of the aggregated data, the research indicates that the assessment of community severance by the analysis of the quality of pedestrian crossings in both railways and urban streets is feasible. Moreover, it also highlights that the distribution of the number of residents surrounding the distinct classes of quality of crossings regarding the railway and urban streets are vertically equitable for vulnerable social groups, except for low-income residents and aged up to 19 years old.

Keywords: Community severance. Transport barriers. Pedestrian crossings. Equity. Geographic Information System - GIS. Census data. 



\section{RESUMO}

LARA, D. V. R. (2019). Avaliação do efeito barreira e da equidade vertical por meio de dados agregados espacialmente. Dissertação (Mestrado). Escola de Engenharia de São Carlos, Universidade de São Paulo, São Carlos, 2019.

Barreiras urbanas relacionadas com transportes são muitas vezes uma consequência: da expansão não planejada de infraestruturas de transporte (ferrovias, vias expressas, rodovias e ruas urbanas), do crescimento de moradias no entorno dessas infraestruturas e do próprio tráfego de veículos. Esse processo, também conhecido como "efeito barreira", é um problema que afeta principalmente grupos sociais vulneráveis (idosos, crianças pequenas e deficientes físicos), e prejudica os deslocamentos ativos. Por este motivo, uma abordagem analítica simples e de baixo custo é proposta para a avaliação do efeito barreira a partir da classificação da qualidade de travessias de pedestres em dois tipos diferentes de infraestruturas de transporte, ferrovias e vias urbanas. Ademais, a abordagem identifica possíveis iniquidades em relação aos dados demográficos agregados espacialmente no entorno dos distintos grupos de classificação. O método para ambas as barreiras de transporte é semelhante, no entanto, devido às suas diferentes características, existem procedimentos específicos para cada. Em geral, os procedimentos de análise que compõem o método, para ambas as infraestruturas de transporte, incluem: coleta de dados, caracterização da barreira de transporte através da avaliação de um conjunto de critérios, classificação da qualidade das travessias de pedestres, análise estatística e análise da equidade vertical. Além disso, dois estudos de caso são apresentados para ilustrar o método. Os estudos de caso compreendem uma ferrovia e vias urbanas localizadas na região urbana da cidade de São Carlos (cidade brasileira de médio porte). Os resultados indicaram evidências de associação entre as variáveis. Adicionalmente, o estudo mostrou evidências de que os moradores próximos à ferrovia e às vias urbanas que possuem baixa renda ou até 19 anos são mal assistidos em relação à mobilidade urbana para pedestres. Portanto, mesmo com a limitação dos dados agregados, a pesquisa indica que a avaliação do efeito barreira a partir análise da qualidade das travessias de pedestres tanto em ferrovias quanto em vias urbanas é viável. Além disso, destaca também que a distribuição do número de moradores ao redor das distintas classes de qualidade de travessias referentes à ferrovia e às vias urbanas é verticalmente equitativa para grupos sociais vulneráveis, com exceção dos moradores de baixa renda e com idade até 19 anos.

Palavras-chave: Efeito barreira. Barreiras de transportes. Travessias de pedestres. Equidade. Sistema de Informação Geográfica - SIG. Dados censitários. 



\section{LIST OF FIGURES}

Figure 3.1 - Example of areas of influence for the railroad crossings and railway..... 41

Figure 3.2 - Overview of the method 43

Figure 3.3 - Example of area of influence for the randomly selected urban streets 44

Figure 3.4 - Schematic drawing of the reference points analyzed in the segments of urban streets

Figure 3.5 - Flow diagram of the analytical procedures that constitute the method 53

Figure 4.1 - Location of the city of São Carlos in the state of São Paulo (a). São Carlos subdivisions into weighting areas (b) and census tracts (c) 55

Figure 4.2 - Weighting areas sectioned by the railway in the city of São Carlos, SP, Brazil .. 56

Figure 4.3 - Location of railroad crossings and segments without railroad crossings in the city of São Carlos, SP, Brazil

Figure 4.4 - Examples of types of crossings and segments without railroad crossings. From top

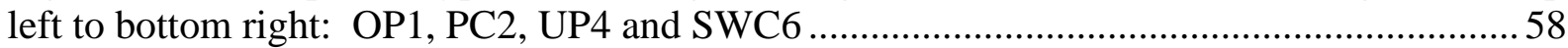

Figure 4.5 - Overview of traffic volumes in the city of São Carlos, SP, Brazil .......................59

Figure 4.6 - Examples of pedestrian crossings on urban streets 60

Figure 5.1 - Total (bar graph) and partial (sector graph) proportions of the number of residents with income as a function of the different classes of railroad crossings and segments without railroad crossings.

Figure 5.2 - Total (bar graph) and partial (sector graph) proportions of the number of residents per class of types of railroad crossings ( $\mathrm{A}$ is the best and D the worst) and segments without railroad crossings as a function of permanent mobility constraints 66

Figure 5.3 - Total (bar graph) and partial (sector graph) proportions of the number of residents by gender as a function of the different classes of railroad crossings and segments without railroad crossings. 66

Figure 5.4 - Total (bar graph) and partial (sector graph) proportions of the number of residents by age range as a function of the different classes of railroad crossings and segments without railroad crossings.

Figure 5.5 - Urban street network, in gray, and random sample $\left(\mathrm{n}_{0}=100\right.$ segments $)$, highlighted in red

Figure 5.6 - Functional classification of the urban streets of São Carlos 76

Figure 5.7 - Crime occurrence per year (from 2010 to 2017) 
Figure 5.8 - Death occurrence per year (from 2010 to 2017) …...........................................78

Figure 5.9 - Number of inhabitants within the areas of influence ........................................79

Figure 5.10 - Land use map in the urban area of São Carlos ................................................. 80

Figure 5.11 - Subsample $01\left(\mathrm{n}_{1}=38\right.$ segments), highlighted in blue (a). Subsample $02\left(\mathrm{n}_{2}=35\right.$ segments), highlighted in green (b). Subsample $03\left(\mathrm{n}_{3}=37\right.$ segments), highlighted in orange (c)

Figure 5.12 - Graph of the number of residents distributed by class of PeCUS index, for each subsample and for each variable

Figure 5.13 - Number of residents by range of monthly nominal income distributed by class of the PeCUS index, for the three subsamples.

Figure 5.14 - Number of residents by permanent mobility constraints distributed by class of the PeCUS index, for the three subsamples

Figure 5.15 - Number of male residents by age distributed by class of the PeCUS index, for the three subsamples

Figure 5.16 - Number of female residents by age distributed by class of the PeCUS index, for the three subsamples 


\section{LIST OF TABLES}

Table 2.1 - Changes in the community severance concept over time 26

Table 2.2 - Synthesis of approaches used for the study of community severance (continued) 28

Table 2.3 - Desirable road characteristics from each functional classification 33

Table 3.1 - Summary of the necessary data for the characterization of transport barriers 38

Table 3.2 - Set of criteria assessed for the distinct types of railroad crossings and segments without railroad crossings (continued)

Table 3.3 - Summary of the criteria assessed for classifying pedestrian crossings on urban streets

Table 3.4 - Summary of the method applied for the assessment of community severance caused by both transport barriers.

Table 3.5 - Steps of the analytical procedures that constitute the method 52

Table 5.1 - Summary of the databases used and their corresponding level of aggregation per transport barrier 62

Table 5.2 - Classification of types of railroad crossings and segments without railroad crossings (as shown in Figure 4.3) according to the percentage of conformance to the analyzed criteria

Table 5.3 - Squared Pearson residuals $\left(\mathrm{PR}^{2}\right)$, standardized Pearson residuals (SPR) and chisquare $\left(\chi^{2}\right)$ test of independence between the variables of classification (of the types of railroad crossings and segments without railroad crossings) and number of residents by range of monthly nominal income

Table 5.4 - Squared Pearson residuals $\left(\mathrm{PR}^{2}\right)$, standardized Pearson residuals (SPR) and chisquare $\left(\chi^{2}\right)$ test of independence between the variables of classification (types of railroad crossings and segments without railroad crossings) and number of residents with self-declared permanent mobility constraints

Table 5.5 - Squared Pearson residuals (PR ${ }^{2}$ ), standardized Pearson residuals (SPR) and chisquare $\left(\chi^{2}\right)$ test of independence between the variables of classification (of the types of railroad crossings and segments without railroad crossings) and number of residents by gender ........ 71

Table 5.6 - Squared Pearson residuals $\left(\mathrm{PR}^{2}\right)$, standardized Pearson residuals (SPR) and chisquare $\left(\chi^{2}\right)$ test of independence between the variables of classification (of the types of railroad crossings and segments without railroad crossings) and number of residents by age range ... 72

Table 5.7 - Summary of excesses and deficits for the variables of classification (of the types of railroad crossings and segments without railroad crossings) regarding income, permanent mobility constraints, gender and age ..... 
Table 5.8 - Number of segments of urban street assigned per class

Table 5.9 - Results of the highest and lowest values for the PeCUS index and their corresponding scores for each criterion assessed (indicated by segment's ID)

Table 5.10 - Subsamples population per variable

Table 5.11 - Squared Pearson residuals ( $\left.\mathrm{PR}^{2}\right)$, standardized Pearson residuals (SPR) and chisquare $\left(\chi^{2}\right)$ test of independence between the variables of class of the PeCUS index and number of residents by range of monthly nominal income

Table 5.12 - Squared Pearson residuals $\left(\mathrm{PR}^{2}\right)$, standardized Pearson residuals (SPR) and chisquare $\left(\chi^{2}\right)$ test of independence between the variables of class of the PeCUS index and number of residents with self-declared permanent mobility constraints

Table 5.13 - Squared Pearson residuals $\left(\mathrm{PR}^{2}\right)$, standardized Pearson residuals (SPR) and chisquare $\left(\chi^{2}\right)$ test of independence between the variables of class of the PeCUS index and number of male residents by age range

Table 5.14 - Squared Pearson residuals $\left(\mathrm{PR}^{2}\right)$, standardized Pearson residuals (SPR) and chisquare $\left(\chi^{2}\right)$ test of independence between the variables of class of the PeCUS index and number of female residents by age range.

Table 5.15 - Summary of excesses and deficits for each class of the PeCUS index per variable for the three subsamples.

Table 5.16 - Summary of the main results from the assessment of community severance regarding railway and urban streets (continues) 
1 INTRODUCTION .................................................................................................................21

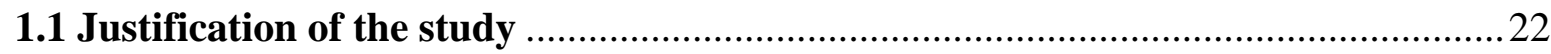

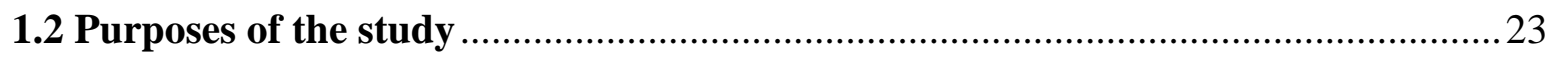

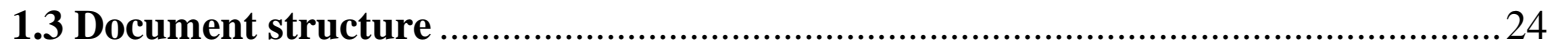

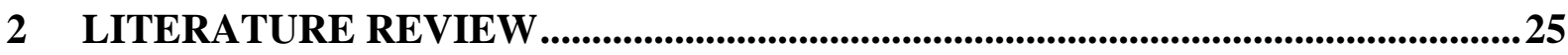

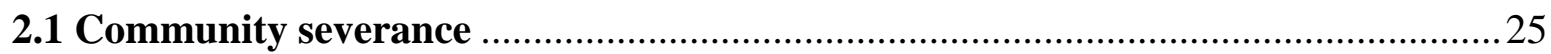

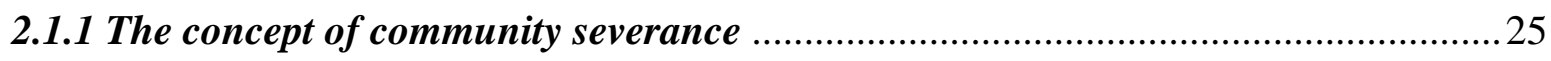

2.1.2 Transport infrastructures as barriers and the community severance approach ...... 26

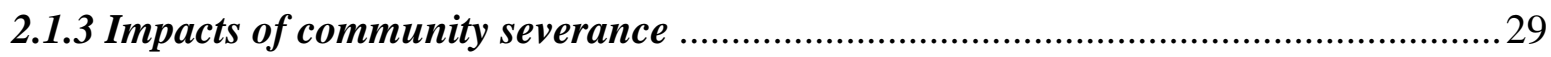

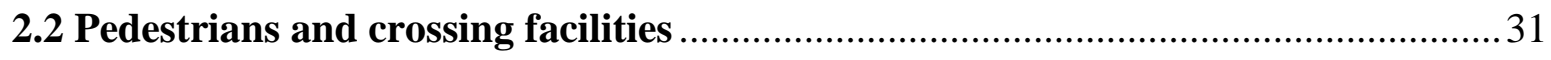

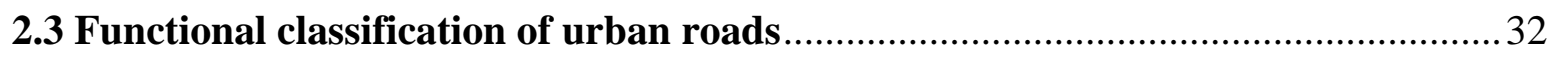

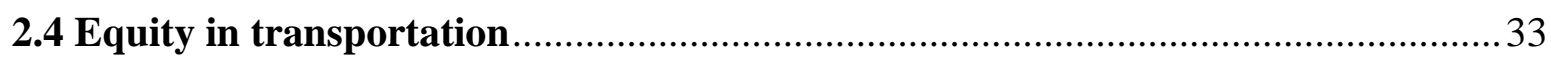

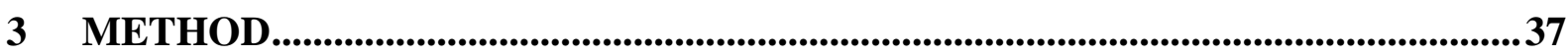

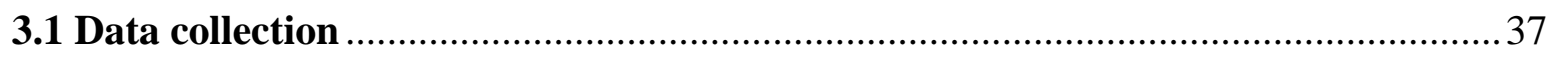

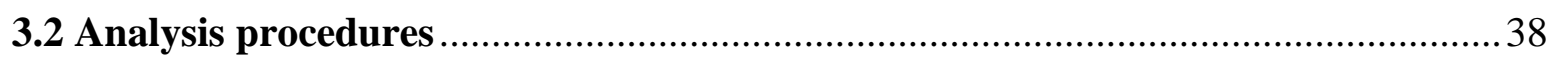

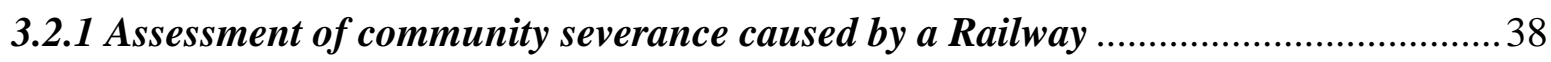

3.2.2 Assessment of community severance caused by Urban Streets ................................ 43

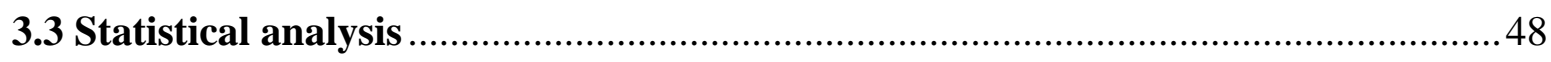

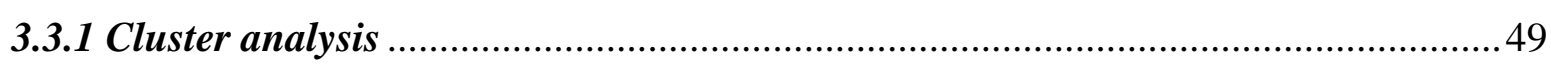

3.3.2 Chi-square $\left(\chi^{2}\right)$ test of independence and standardized Pearson residuals ............. 49

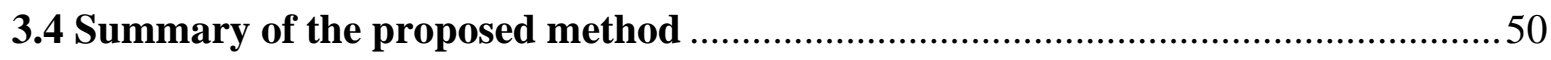

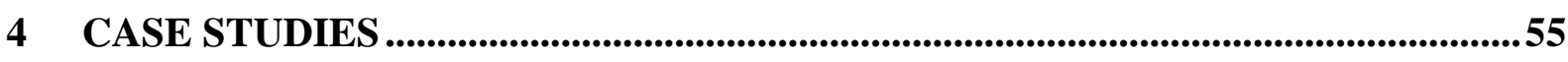

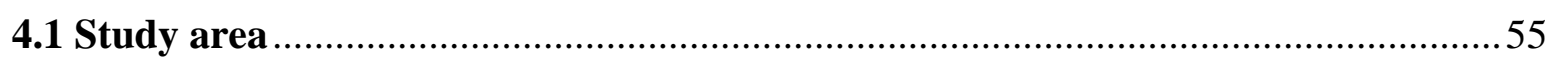

4.2 Case study 01: Railway within the urban perimeter ........................................56

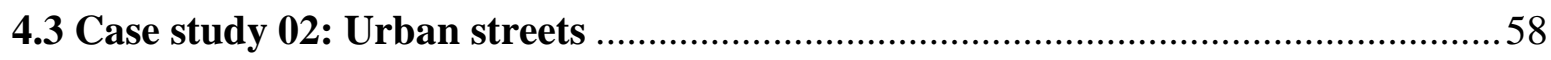

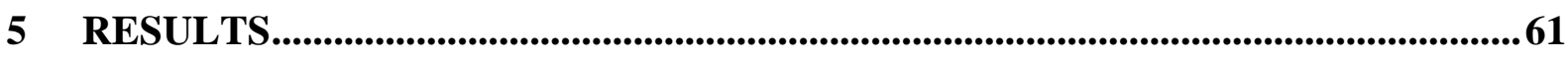

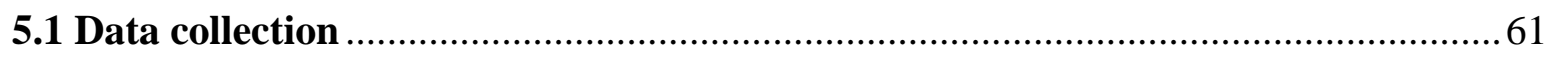

5.2 Case study 01: Assessment of the community severance caused by a Railway....... 63

5.2.1 Classification of the types of railroad crossings and the segments without railroad

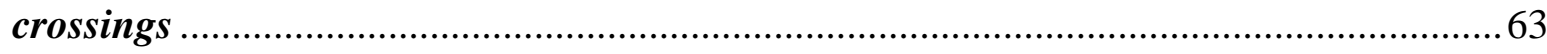

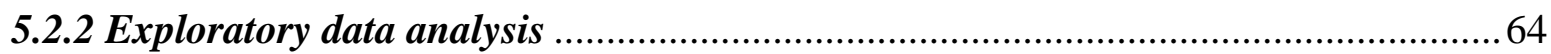

5.2.3 Chi-square $\left(\chi^{2}\right)$ test of independence and standardized Pearson residuals ............. 67 
5.3 Case study 02: Assessment of the community severance caused by Urban Streets 74

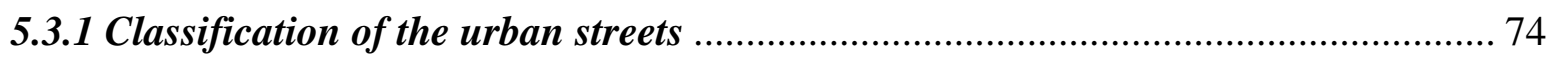

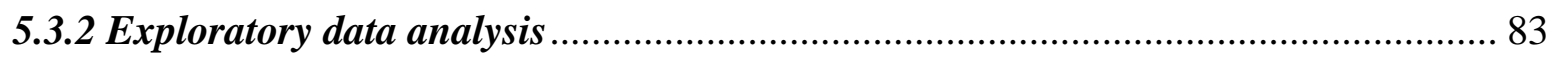

5.3.3 Chi-square $\left(\chi^{2}\right)$ test of independence and standardized Pearson residuals .............. 88

5.4 Summary of the assessment of the community severance caused by transport

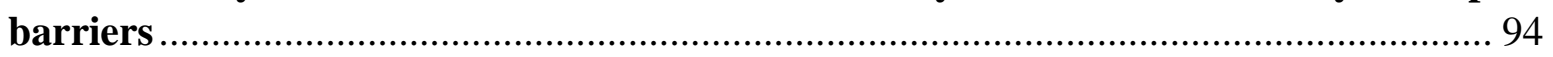

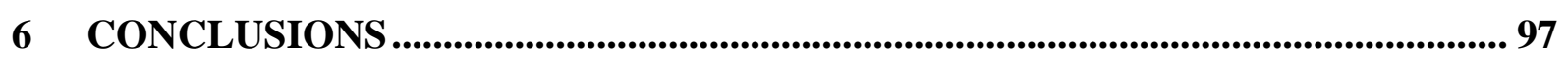

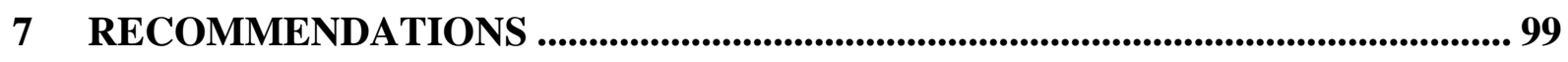

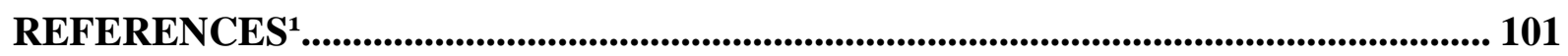




\section{INTRODUCTION}

According to Vasconcellos (2016), an intense and fast urbanization process results in larger urban areas, more trips and longer distances traveled, particularly for those living far from the central area. With longer distances, the dependence on trips by motorized vehicles increases, as well as the need of transport infrastructures to meet the growing demand. This process not only affects the travel patterns of the population, but also negatively impacts different city functions (e.g. land uses, real estate development, etc.) and creates barriers to adjacent communities.

Urban barriers are often a consequence of the unplanned expansion of transport infrastructures (railways, freeways, roadways and urban streets), housing growth around those infrastructures, and the vehicular traffic itself. This process, also known as "community severance", is a problem that mainly affects vulnerable social groups (the elderly, young children and the physically disabled). It also negatively affects cycling and walking trips. Moreover, it has increasingly attracted the attention of urban and transport planners, in part because of the growing need to replace the use of motorized vehicles with active transport, especially in large urbanized areas. Additionally, the social impact of transport is also a growing area of concern and it can no longer be measured simply in terms of its performance but as an enabler or barrier to improving quality of life (Woodcock, 2018).

Community severance is formally defined as a physical impedance to walking trips (Soguel, 1995; Guo, Black, \& Dunne, 2001; Mouette \& Waisman, 2004; Anciaes, Boniface, Dhanani, Mindell, \& Groce, 2016) and to the access to goods, services and people (Scholes, Boniface, Stockton, \& Mindell, 2016; Mindell et al., 2017) due to transport infrastructures, traffic streams and speeds (Guo et al., 2001; Anciaes, 2015; Anciaes et al., 2016; Scholes et al., 2016). In addition, community severance is related to psychological barriers separating local communities (Taylor \& Crawford, 2009; Scholes et al., 2016), affecting perceptions, behavior, stress (Appleyard \& Lintell, 1972; Hine \& Russell, 1993; Hart \& Parkhurst, 2011), safety perceptions (Hine, 1996; Davis \& Jones, 1997; Timperio et al., 2006; Hart \& Parkhurst, 2011), wellbeing (Timperio et al., 2006; Scholes et al., 2016; Foley et al., 2017; Nimegeer et al., 2018; Anciaes, Stockton, Ortegon, \& Scholes, 2019), health (Timperio et al., 2006; Mackett \& Thoreau, 2015; Scholes et al., 2016; Foley et al., 2017; Nimegeer et al., 2018), social interactions (Appleyard \& Lintell, 1972; Davis \& Jones, 1997; Hart \& Parkhurst, 2011; Scholes et al., 2016; Nimegeer et al., 2018) and intensifying social exclusion (Rajé, 2004; Mackett \& 
Thoreau, 2015) of people who live or use the surrounding areas or need to make trips along or across that infrastructure or traffic stream (Anciaes, 2015).

Therefore, community severance is a complex and interdisciplinary issue that causes negative impacts to society and transport systems. However, urban and transport planners still have difficulties to understand the variations of community severance caused by distinct transport infrastructures.

\subsection{Justification of the study}

Community severance has been studied since the 1960s and has already been integrated into the mobility guidelines of some countries. In Brazil, however, the Urban Mobility Plan (or PlanMob, which in Portuguese stands for Plano de Mobilidade Urbana) proposed by the Ministry of Cities more than a decade ago (Ministry of Cities, 2007), does not approach the impacts of community severance on pedestrians' mobility and on communities' social exclusion.

In addition, given the different types and characteristics of transport infrastructures, the intensity and variability of community severance can be substantially high. Accessible and safe pedestrian crossings, for example, can contribute to reducing the impacts of community severance on walking trips because they regulate the preference of passage of motorized and non-motorized traffic. Regarding road infrastructures, impacts can be high in the case of freeways, and from moderate to low in the case of urban streets with pedestrian crossings, with high variability along any single element of infrastructure. For transport infrastructures with a clear physical segregation (e.g. rivers and railways), the impact can be large and the variability small.

Railways in urban areas are also a cause of community severance, given that the passage of motorized vehicles, pedestrians and cyclists is only possible in the specific points where there are railroad crossings. However, relatively few studies have been conducted on railways (e.g. Sousa, Sousa \& Braga 2009; Taylor \& Crawford, 2009; Chang, Han, Jung \& Kim, 2014; Lee \& Sohn, 2014; Lara \& Rodrigues da Silva, 2018) whereas there are considerably more studies on urban streets (e.g. Appleyard \& Lintell, 1972; Soguel, 1995; Hine, 1996; Mouette et al., 2000; Guo et al., 2001; Mouette \& Waisman, 2004; Silva Jr \& Ferreira, 2008; Hart \& Parkhurst, 2011; Cantillo et al., 2015; Mindell et al., 2017).

Urban and transport planners are also concerned about inequalities in the distribution of different social groups around transport infrastructures, the quality of these transport infrastructures and the exposure to transport-related externalities. Litman (2002) presented two 
categories of equity: horizontal and vertical. Horizontal equity involves the distribution of resources equally to each individual or group, whereas vertical equity implies in the distribution of resources according to each individual or group special needs, in order to ensure that their situation are not made worse off, and that their needs are accommodated. In this study, we used the vertical equity concept.

In summary, community severance may affect the daily activities and the behavior of people of distinct demographic characteristics and at different levels. The analysis of this interdisciplinary effect involves many variables and tools, which sometimes demands qualified and well-trained professionals (e.g. for specific data collection procedures), commitment from the target population, costly technologies and restricted-access data. The development of simple and efficient methods can help to predict and assess actions and policies to minimize community severance impacts. For this reason, we proposed a combination of census data, open access data and free Geographic Information System software, which may save time, effort and financial resources, into a single approach for the analysis of equity issues related to community severance.

The proposed approach can help to answer the following questions: Is it possible to assess community severance by analyzing the quality of pedestrian crossings? Is there evidence of association between the distribution of residents with distinct demographic characteristics around urban barriers and the quality of pedestrian crossings? Is the residents' distribution vertically equitable?

\subsection{Purposes of the study}

The main objective of this study is to develop a simple and low-cost analytical approach to assess community severance based on a classification of the quality of pedestrian crossings on two different types of transport infrastructures, a railway and a sample of urban streets, and to apply it in a Brazilian medium-sized city.

Furthermore, secondary objectives include: (i) constructing an index capable of estimating the quality of pedestrian crossings on urban streets, and (ii) identifying possible inequities regarding demographic data (income, permanent mobility constraints, gender and age) in the surroundings of the distinct classes of quality of pedestrian crossings for both infrastructures. 


\subsection{Document structure}

The present thesis was divided into seven chapters. The first chapter comprises a brief introduction and contextualization of the problem approached, as well as the justification and the objectives of the research. Subsequently, in Chapter 2, we present the state-of-the-art on community severance with a focus on the concept evolution, study approaches and findings. This Chapter also covers pedestrian preferences for crossing facilities, the functional classification of urban roads and concepts of equity.

Chapter 3 describes the necessary data and the method proposed for assessing community severance caused by two transport barriers, i.e. a railway and urban streets. The presentation of the case studies used to illustrate the method are indicated in Chapter 4.

In Chapter 5, we present and discuss the results obtained from the assessment of community severance and, in Chapter 6, the conclusions are drawn. Finally, in Chapter 7, recommendations for future work are indicated. 


\section{LITERATURE REVIEW}

This Chapter presents, in four Sections, an overview of the literature on the main concepts and findings used to develop this research. The first Section describes a brief background on community severance, focusing on the concepts of definition, approach and impacts. The second Section covers pedestrian preferences for crossing facilities. In the third Section, the functional classification of urban roads is addressed, while the fourth Section presents concepts of equity.

\subsection{Community severance}

This Section presents a literature review on community severance divided into the following topics: the evolution of the concept since 1960, when the topic became well-known; approaches commonly used in the characterization of transport barriers and community severance and impacts on the most affected social groups.

\subsubsection{The concept of community severance}

The concept of community severance has undergone changes according to the progress of research in the different fields of knowledge. Based on the synthesis presented in Table 2.1, we propose the following definition of community severance:

Community severance is characterized by physical and psychological barriers that cause impedances to pedestrian movements (limiting the access to goods, services and people) and affects pedestrian networks (with impacts on connectivity, permeability and accessibility of pedestrian pathways); inhibits social interactions; interferes negatively on the behavior, perception, wellbeing, mental and physical health of people who live or use the surrounding areas and separates local communities due to transport infrastructures, traffic streams and speeds. 
Table 2.1 - Changes in the community severance concept over time

\begin{tabular}{lcc}
\hline \multicolumn{1}{c}{ Concept } & Author & Country \\
\hline $\begin{array}{l}\text { Undesirable division of an area of closely inter-related uses by a road carrying } \\
\text { a heavy traffic flow }\end{array}$ & $\begin{array}{c}\text { UK MOT } \\
(1963)\end{array}$ & $\begin{array}{c}\text { United } \\
\text { Kingdom }\end{array}$ \\
\hline $\begin{array}{l}\text { Effect of traffic stream on the environmental (concern for safety, stress, } \\
\text { noise and pollution) and social (social interactions and street activity) quality } \\
\text { of streets }\end{array}$ & $\begin{array}{c}\text { Appleyard and } \\
\text { Lintell (1972) }\end{array}$ & USA \\
\hline $\begin{array}{l}\text { Effects of traffic conditions (speed and flow) upon pedestrian movement, } \\
\text { crossing behavior and perception of the street (trip change or suppression) }\end{array}$ & $\begin{array}{c}\text { Hine and } \\
\text { Russell (1993) }\end{array}$ & $\begin{array}{c}\text { Kningdom } \\
\text { Kingded }\end{array}$ \\
\hline $\begin{array}{l}\text { Nuisances caused to both movement function and social function (playing and } \\
\text { strolling) of the pedestrian network }\end{array}$ & $\begin{array}{c}\text { Soguel } \\
\text { (1995) }\end{array}$ & Switzerland \\
\hline
\end{tabular}

Problems caused to pedestrian movement due to static severance and dynamic severance. Static severance is caused by the introduction of a new highway with access control and high embankments where there are existing patterns of social interaction. Dynamic severance is caused by vehicular traffic on urban streets and imposes problems for pedestrian movement

Guo et al. (2001)

Australia

Restrictions or inhibitions on the free pedestrian movement between the two sides of the road caused by the traffic stream and by the road infrastructure itself

Mouette and

Waisman Brazil

(2004)

Restrictions on walking and on proper use of city spaces by the residents of urban areas that are sectioned by highways

Silva Jr. and Ferreira (2008)

Brazil

Behavior and perception of residents about the impacts of motor traffic on their homes and streets, and on individual and community mental and physical health

Hart and

Parkhurst

(2011)

United

Kingdom

Variable and cumulative negative impact of the presence of transport infrastructure or motorized traffic on the perceptions, behavior, and wellbeing of people who use the surrounding areas or need to make trips along or across that infrastructure or traffic stream

Anciaes United

(2015) Kingdom

The 'barrier-effect' of the speed or the volume of traffic, or other transport infrastructure, on access to goods, services and people, which can represent physical and psychological barriers separating local communities

Scholes et al. United

(2016) Kingdom

Continuum stemming from the presence of transport infrastructure or motorized traffic and including chain of effects at the individual or community level, which acts as a physical or psychological barrier to the movement of pedestrians. In addition, it is related not only to the physical characteristics of the road (such as traffic volume, speed, and composition) but

Anciaes et al. United (2016) Kingdom also to the perceptions of people living near the road

Source: The author

\subsubsection{Transport infrastructures as barriers and the community severance approach}

Diverse transport infrastructures and their motorized traffic stream act as urban barriers to active trips. This is a problem that has increasingly attracted the attention of urban and transport planners, in part because of the growing need to replace the use of motorized transport with active transport, especially in main urban centers. 
Community severance caused by railways in urban areas remarkably segregates communities, inhibits social interactions and hampers the free crossing between both sides of the railway. That is because railways in urban areas are demanded to have physical barriers throughout their entire way, in order to avoid accidents. Thus, the passage of motorized vehicles, pedestrians and cyclists is only eligible where there are railroad crossings. Although railways comprise a notable case of community severance there are still relatively few studies focusing on them (e.g. Sousa, Sousa \& Braga, 2009; Taylor \& Crawford, 2009; Chang, Han, Jung \& Kim, 2014; Lee \& Sohn, 2014; Lara \& Rodrigues da Silva, 2018).

On the other hand, road infrastructures are part of the urban space and are present in the daily lives of pedestrians. However, the community severance caused by road infrastructures is more difficult to characterize than in the case of railways, given that pedestrians can eventually reach the other side of the road. In other words, depending on the traffic stream volume and road characteristics, pedestrians can cross either on crossing facilities (formal passage) or between car gaps (informal passage). There are considerably more studies on urban streets (e.g. Appleyard \& Lintell, 1972; Soguel, 1995; Hine, 1996; Mouette et al., 2000; Guo et al., 2001; Mouette \& Waisman, 2004; Silva Jr \& Ferreira, 2008; Hart \& Parkhurst, 2011; Cantillo et al., 2015; Mindell et al., 2017) than studies on railways.

The data collection instruments and analytical tools commonly used in community severance studies include questionnaires (Davis \& Jones, 1997; Mouette, Aidar, \& Waisman, 2000; Mouette \& Waisman, 2004; Timperio et al., 2006; Scholes et al., 2016; Foley et al., 2017; Mindell et al., 2017; Anciaes et al., 2019), interviews (Soguel, 1995; Hine, 1996; Silva Jr \& Ferreira, 2008; Hart \& Parkhurst, 2011; Cantillo, Arellana, \& Rolong, 2015; Nimegeer et al., 2018), workshops (Taylor \& Crawford, 2009; Anciaes et al., 2016), focus groups (Cantillo et al., 2015; Mindell et al., 2017), open data (Mouette \& Waisman, 2004; Lee \& Sohn, 2014; Lara \& Rodrigues da Silva, 2018), empirical data collection (Guo et al., 2001; Mouette \& Waisman, 2004; Mindell et al., 2017; Lara \& Rodrigues da Silva, 2018; Anciaes et al., 2019), video surveys (Hine, 1996; Mindell et al., 2017; Anciaes et al., 2019), participatory mapping, interdisciplinary analysis (Mindell et al., 2017), spatial analysis (Mindell et al., 2017; Lara \& Rodrigues da Silva, 2018; Anciaes et al., 2019) and equity analysis (Litman, 2002; Jang, An, Yi, \& Lee, 2017; Lara \& Rodrigues da Silva, 2018; Pereira, 2018). 
Table 2.2 - Synthesis of approaches used for the study of community severance (continued)

\begin{tabular}{lcc}
\hline \multicolumn{1}{c}{ Approach } & Author & Country \\
\hline $\begin{array}{l}\text { The report identifies perceptions of those who live around city streets in San } \\
\begin{array}{l}\text { Francisco about the effects of traffic on the environmental and social quality of } \\
\text { these streets using observation and open response interview techniques }\end{array}\end{array}$ & $\begin{array}{c}\text { Appleyard } \\
\text { and Lintell } \\
(1972)\end{array}$ & USA \\
\hline $\begin{array}{l}\text { The study proposes a contingent valuation survey to predict the bids to infer the } \\
\text { annual cost (willingness to pay) of removing the community severance caused by } \\
\text { a road around the city center of Neuchâtel, Switzerland }\end{array}$ & $\begin{array}{c}\text { Soguel } \\
(1995)\end{array}$ & Switzerland \\
\hline $\begin{array}{l}\text { The paper identifies the role that qualitative techniques (in-depth interviews, } \\
\text { questionnaires and video recordings) can play in assessing the impact of traffic } \\
\text { conditions on pedestrian behavior and perceptions of safety on selected high- } \\
\text { density, radial mixed-use streets in Edinburgh }\end{array}$ & $\begin{array}{c}\text { Hine } \\
\text { (1996) }\end{array}$ & $\begin{array}{c}\text { Kingdom } \\
\text { Kinded }\end{array}$ \\
\hline
\end{tabular}

The study portrays the changes in the concept of community severance over time, and defines static and dynamic severance. It proposes a new model of pedestrian delay incorporating the bunched characteristics of urban traffic flow caused by traffic signalisation. The model validation was performed through field measurements conducted in Sydney

The research proposes a systemic model considering influence elements, causative elements and impacts of community severance. The model validation is performed through a field survey

Guo et al. (2001)

Australia

The study proposes the determination of the degree of variables importance for characterizing community severance impacts through questionnaires (with Likert scale) that evaluate the perceptions of residents nearby an expressway in the city of Uberlândia, Brazil

Mouette and

Waisman Brazil

(2004)

Silva Jr. and

Ferreira Brazil

(2008)

The study addresses the intra-urban structure, community severance and dynamics of mobility and accessibility in the city of Rio Claro, Brazil, based on the urban design (zoning and land use) of city districts

Sousa et al. (2009)

Brazil

The study estimates the benefits (cost savings by the project or by the willingness of the public to pay for the changes) of rerouting a railway line as underground tunnels in Seoul, Korea

Chang et al.

Korea

The study proposes a broad definition for community severance based on the analysis of an extensive collection of definitions found in the literature and on discussions held as part of the "Street Mobility and Network Accessibility" research project

The study proposes a model of pedestrian behavior and choice preference crossings (crossing directly, crossing by using a pedestrian bridge or using a crosswalk at a signalized intersection) on a street intersection in Bogota, Colombia, through a stated preference survey designed with the help of a focus group and expert opinions
Cantillo et

al. (2015)

Colômbia
Anciaes United

(2015) Kingdom

The research proposes the integration between the different disciplines working separately in the development of policy solutions by means of a crossdisciplinary research on community severance, built on the reflections obtained in workshops attended by local authorities, non-governmental organizations, and consultants

al. (2016) Kingdom

The working paper describes a survey questionnaire component of the toolkit designed to measure community severance and assess its potential associations with transport and health in two contrasting roads in inner London

The research recommends guidelines for the consolidation of the wide variety of methods found in the literature into a consistent framework for the integration of severance at three stages of transport planning: problem identification, option generation, and option appraisal 
Table 2.2 - Synthesis of approaches used for the study of community severance (conclusion)

The study conducts a stated preference survey in the areas surrounding two busy roads in the United Kingdom. The survey considers people's preferences regarding crossing roads (informally, walking further and crossing where the road is covered over, or avoid crossing altogether) with different characteristics (number of lanes, presence of a median strip, traffic density, and traffic speeds)

Anciaes,

Jones and

Mindell

(2017)

The study developed an interdisciplinary suite of tools to measure and value community severance based on: participatory mapping, spatial analysis, a video survey, street audits, a health and neighborhood mobility survey, and a stated preference survey, undertaken as part of the "Street Mobility and Network Accessibility" research project

The report provides information and guidelines for the development of sustainable integrated transport measures. The distributional impacts caused by transport (noise, air quality, accidents, community severance, security, accessibility and personal affordability) are analyzed regarding their effects on individual social groups, and between the different social groups.

(2018) Kingdom

Source: The author

\subsubsection{Impacts of community severance}

The main affected population groups identified in the literature correspond to the elderly, children (Hine, 1996; Mouette \& Waisman, 2004), residents who have a long-standing illness (Scholes et al., 2016; Foley et al., 2017), adults who need to accompany another individual with restricted mobility (Mouette \& Waisman, 2004), people who have great difficulty or some difficulty in walking or climbing stairs and a particular lower income group (Lara \& Rodrigues da Silva, 2018). As community severance mainly affects vulnerable groups (the elderly, very young children and the physically disabled), it is reasonable to consider an area of influence compatible with the walking distances of those groups' conditions in order to analyze the community severance effect caused by specific transport infrastructures.

Walking distances should encompass suitable distances to be covered by most people, especially vulnerable groups, which cannot walk long distances and for long periods. In this respect, the urban design concept proposed by Burton and Mitchell (2006) highlights the importance of considering people's physical constraints when defining walking distances. However, studies about community severance do not seem to have a consensus about walking distances, ranging around 300 and 800 meters. Anciaes et al. (2019) defined a walking distance of 400 meters from busy roads. Rosenlieb, McAndrews, Marshall and Troy (2018) used a 300meter bandwidth to represent the varying intensity of exposure to traffic with distance and another study by Anciaes (2013) used threshold values of 500 and 800 meters. In addition, Pereira (2018) used catchment area analysis to estimate the number of people from different 
income groups who can reach relevant locations from their homes within a certain travel time threshold (15, 30, 60 and 90 minutes) using only public transport and walking.

The impacts of community severance are related to trip diversion and suppression (Hine, 1996; Guo et al., 2001; Silva Jr \& Ferreira, 2008), poor accessibility and restricted personal mobility in the affected neighborhoods (Guo et al., 2001), affecting pedestrians not only when they cross roads but also when they walk along them (Silva Jr. \& Ferreira, 2008; Anciaes et al., 2016; Scholes et al., 2016).

In relation to railways, the impacts on community cohesion due to grade railway crossings could be positive or negative, since lowering the railway reduces community severance by making surface movement easier for pedestrians, cyclists and drivers and in locations where a road overpass has been built. However, community severance may be worsened due to the intrusion of the elevated structure and its approaches (Taylor \& Crawford, 2009). In addition, railway grade crossings affect the accessibility of pedestrians with disabilities or wheelchair users, generally due to rough surfaces and physical obstructions causing travel delay (McPherson \& Daff, 2005).

Furthermore, the community severance caused by different types of transport infrastructures affects the perceptions, behavior, stress (Appleyard \& Lintell, 1972; Hine \& Russell, 1993; Hart \& Parkhurst, 2011), safety perceptions (Hine, 1996; Davis \& Jones, 1997; Timperio et al., 2006; Hart \& Parkhurst, 2011), wellbeing (Timperio et al., 2006; Scholes et al., 2016; Foley et al., 2017; Nimegeer et al., 2018; Anciaes, Stockton, Ortegon, \& Scholes, 2019), health (Timperio et al., 2006; Mackett \& Thoreau, 2015; Scholes et al., 2016; Foley et al., 2017; Nimegeer et al., 2018), social interactions (Appleyard \& Lintell, 1972; Davis \& Jones, 1997; Hart \& Parkhurst, 2011; Scholes et al., 2016; Nimegeer et al., 2018) and intensifies social exclusion (Rajé, 2004; Mackett \& Thoreau, 2015) of people who live or use the surrounding areas or need to make trips along or across that infrastructure or traffic stream (Anciaes, 2015).

According to Anciaes, Jones and Metcalfe (2018), the economic value of negative impacts on transport systems are relevant for decisions about pricing policies and investment in transport system. Under this direction, Anciaes, Jones and Mindell (2016), proposed guidelines for the consolidation of the wide variety of methods found in the literature into a consistent framework to identify and monetarize the effects of severance on communities, people's wellbeing and behavior. 


\subsection{Pedestrians and crossing facilities}

Crossing facilities in transport infrastructures have the function of ensuring users' (pedestrians, cyclists and drivers) right of way safely. However, they do not always benefit pedestrian movements. Due to the type of crossing facility, its conservation status and location, on-site public lighting, among other factors, there may be pedestrian delays, risks of trampling, robbery or violence. In this case, the crossing comprises a physical and psychological barrier, which can also cause walking trip diversion or suppression. According to Hine and Russell (1993) there is a trade-off between pedestrian mobility and safety which is of direct relevance to the implementation of traffic calming schemes on more heavily trafficked roads.

Based on the guidelines from the National Department of Transport Infrastructure - in Portuguese: DNIT - Departamento Nacional de Infraestrutura de Transportes - (DNIT, 2010), pedestrians prefer level crossings and avoid underground passages and footbridges, even though they are well designed and safe. The guidelines also suggest that preferences are due to deviations caused to their natural paths, often increasing travel times, travel distances, and energy expenditures. In addition, underground passages are potential areas of crime, which reduce their use.

Additionally, according to the study conducted by Mindell et al. (2017), crossing is risky and unpleasant due to the exposure of pedestrians to moving traffic, even though there are no physical barriers preventing pedestrians from crossing (such as guard railings, fences, or walls). In general, the presence of a median strip aids pedestrians crossing the road, by splitting the crossing into two stages. However, in many cases, median strips can become an additional barrier, if they have steps or uneven surfaces, making them inaccessible to people with mobility restrictions. Even narrow roads can become barriers to the movement of pedestrians, if they have high traffic densities or speeds, reducing the ability of pedestrians to cross and walk along the road. The study results indicated that participants prefer to avoid crossing roads with no crossing facilities. In addition, the level of the barrier effect of roads on pedestrians was positively related with the road characteristics (number of lanes, traffic density and traffic speed) and the presence of a median strip decreased the barrier effect.

The results from Sisiopiku and Akin's (2003) study support the notion that properly designed and placed pedestrian facilities encourage users to cross at safer proposed locations. Despite the presence of signalized intersections with crosswalks, pedestrians still do not comply with the signal indication (particularly under low traffic demand conditions). Convenience and 
distance of the crosswalk were also pointed out as important factors for crossing at a designated crossing location.

The findings in the research conducted by Cantillo et al. (2015) suggested that: pedestrians are more prone to using the alternative route involving less walking distance (crossing directly), pedestrian bridges were identified as non-effective crossings, and the probability for pedestrians to choose safer alternatives for crossing diminished with large distances. Furthermore, when traffic flow is high and delay increases, the propensity for direct crossings decreased.

The study developed by Hine (1996) indicated that the elderly, particularly those with health-related mobility constraints, and children were identified as more likely to cross using crossing facilities. In addition, Lee and Sohn (2014) concluded that the land price of areas along at-grade or elevated railways are much less than the areas along underground railways.

\subsection{Functional classification of urban roads}

The functional classification suggested by DNIT (2010) is based on the process in which roads are hierarchically grouped into subsystems, according to the type of service they offer and the function they carry out within the road system in the traffic flow. Functional classification is usually established according to the mobility (ease of travel) and the accessibility (facility that a road provides to connect the origin of a trip to its destination) that are enabled. Thus, urban roads are classified into four basic systems:

- Primary arterial system: this includes roads that serve mostly direct traffic, usually in continuous routes, but do not have the technical characteristics of an expressway. The system provides a high degree of mobility for longer trips, offering high operating speeds and service levels.

- Secondary arterial system: this includes urban roads that interconnect to the primary arterial system and supplement it, attending travel routes at a service level lower than that provided by the primary arterial roads. This system serves trips with a lower mobility degree and distributes the traffic through smaller areas than the primary system. It provides direct access to properties and the roads can accommodate local bus lines, providing continuity between communities, although avoiding entering these communities.

- Collector system: connects local streets with arterial roads, providing continuity at the level of local communities or urban subdivisions, but at low speeds. It 
differs from the arterial system, because the roads from the collector system can penetrate in the residential neighborhoods, distributing the traffic of the arterial roads, through the area, to their final destinations.

- Local system: enables the access to properties that are adjacent to higher order systems, offers the lowest level of mobility and usually does not contain bus routes.

Table 2.3 - Desirable road characteristics from each functional classification

\begin{tabular}{ccccc}
\hline $\begin{array}{c}\text { Project and control } \\
\text { characteristics }\end{array}$ & Primary arterial system & $\begin{array}{c}\text { Secondary arterial } \\
\text { System }\end{array}$ & $\begin{array}{c}\text { Collector } \\
\text { System }\end{array}$ & $\begin{array}{c}\text { Local } \\
\text { system }\end{array}$ \\
\hline $\begin{array}{c}\text { Traffic control at } \\
\text { intersections }\end{array}$ & $\begin{array}{c}\text { Traffic lights, "Stop" } \\
\text { signs on secondary } \\
\text { roads }\end{array}$ & $\begin{array}{c}\text { Traffic lights, "Stop" } \\
\text { signs on secondary } \\
\text { roads }\end{array}$ & $\begin{array}{c}\text { Traffic lights, "Stop" } \\
\text { signs on secondary } \\
\text { roads }\end{array}$ & $\begin{array}{c}\text { "Stop" } \\
\text { signs }\end{array}$ \\
\hline $\begin{array}{c}\text { Access to adjacent } \\
\text { properties }\end{array}$ & Restricted & Restricted or free & Free & Free \\
\hline Pedestrian crossings & $\begin{array}{c}\text { Different levels or } \\
\text { zebra crossing }\end{array}$ & $\begin{array}{c}\text { Different levels or } \\
\text { zebra crossing }\end{array}$ & Zebra crossing & Free \\
\hline Median & Where possible & Generally, not & No & No \\
\hline Parking & Controlled & Controlled & Controlled or free & Free \\
\hline Shoulder & None or parking strip & None & None & None \\
\hline Source DNIT 2010$)$ & & &
\end{tabular}

Source: DNIT (2010)

\subsection{Equity in transportation}

According to Litman (2002), the concept of equity could be divided into two categories: horizontal and vertical. Horizontal equity involves the distribution of resources equally to each individual or group, whereas vertical equity implies in the distribution of resources according to each individual's or group's special needs in order to ensure they are not worse off, and that their needs are accommodated.

In the study developed by Shirmohammadli, Louen and Vallée (2016), the necessity of mobility equity analyses in transportation systems of societies with an increasing number of non-drivers is highlighted. The study explores the horizontal and vertical mobility equity statuses of various districts and socioeconomic groups in the city of Aachen, Germany. The study indicated that the distribution of mobility between the inhabitants of different districts is overall horizontally equitable, while the vertical equity analysis shows a significant variation between different socioeconomic groups and different transportation modes.

According to Tsou, Hung and Chang (2005), spatial equity means equal spatial separation from or spatial proximity to public facilities among residents. Moreover, spatial equity is often defined and measured by the level of accessibility (Kelobonye et al., 2019). 
Jang et al. (2017) developed a methodology for calculating the index of the spatial equity for the public transportation services for the city of Seoul using the Lorenz curve and Gini coefficient based on accessibility to the services. They suggest that equity in public transportation in a city is closely related with horizontal equity, which could arise from the spatial structure in terms of, for example, access to a transit node without much effort. Such equity means public transportation lines and routes are well distributed in consideration of the urban spatial structure of the city. In addition, they pointed out that generally the two types of public transportation equity are observed together in a city without any apparent linkage between them. There could be vertical inequity in a city with high horizontal equity, where the accessibility to public transportation services is good overall, if the city shows severe differences in income levels locally.

Pereira, Schwanen and Banister (2017) defined justice as a broad moral and political ideal that relates to how benefits and burdens are distributed in society (distributive justice); the fairness of processes and procedures of decision and distribution (procedural justice); and the rights and entitlements which should be recognized and enforced. In their study, they reviewed key theories of justice (utilitarianism, libertarianism, intuitionism, Rawls' egalitarianism and capability approaches) and discussed some of their insights and limitations when applied to issues of transport disadvantage, social exclusion, and accessibility. According to the authors, investments in public transport and cycling/walking can be good ways of prioritizing transport modes which are more widely used by low-income classes. To be considered fair, however, these investments should not override the social rights of families (e.g. with eviction of families due to the infrastructure projects). The distributional effects of such investments should be evaluated in terms of the extent to which they reduce inequalities in transport accessibility, particularly by improving the accessibility levels of low-income public transport-dependent groups to key destinations such as employment opportunities, healthcare, and education services. Moreover, this perspective also calls for complementary policies that discourage car use in highly congested and polluted areas to mitigate the negative externalities imposed by drivers on everyone else, particularly on vulnerable populations.

Massive transport investments during preparation for hosting sports mega-events, such as the FIFA World Cup and the Olympic Games, can substantially change the organization of urban space, making it crucial to evaluate whether local governments mobilize these events in a way that redresses or reinforces existing patterns of urban inequality and segregation (Pereira, 2018). In his study, Pereira (2018) reflects on the delimitation of transport legacies and its social impacts in terms of how mega-events in Rio de Janeiro can reshape urban accessibility to 
opportunities. The study found out that the changes made to the city's transport system have exacerbated socio-spatial inequalities by reducing the ability of the population, particularly of low-income transit-dependent groups, to access medium and high-complexity healthcare facilities. Therefore, the author concluded that the evaluation of mega-events' impacts and transport legacies cannot be disconnected from a critical analysis of equity, that is, a critical analysis of who benefits from such investments, as well as where and how these benefits are realized.

In a micro-scale level, Bereitschaft (2017) qualitatively assessed streetscapes environment and explored possible inequalities among neighborhoods with similar walkability (according to macro-scale indices) but with different social vulnerability. The study suggests that there are disparities at a micro-scale level and that they should be analyzed along with macro-scale elements, such as: density, connectivity, transit accessibility, and land use mix.

In addition, the study developed by Lara and Rodrigues da Silva (2018) introduces the characterization of the community severance caused by a railway in the urbanized area of a medium-sized Brazilian city. Moreover, it also investigates equity issues for residents alongside the railway and nearby the distinct types of crossings regarding the population characteristics, through chi-square tests of independence and descriptive analysis.

The analysis of the community severance caused by transport infrastructures still requires more detailed studies. However, data collection at a disaggregated level is sometimes impractical as it can demand considerable time, financial assistance and the support of qualified and well-trained professionals. In other words, the analysis of the community severance involves a complex process, in which the development of simple and low-cost methods combined with using open data and census data can assist the decision-making of urban and transport planners in order to minimize community severance impacts.

For this reason, in this study we proposed an analytical approach to assess community severance based on the classification of the quality of pedestrian crossings on two different types of transport infrastructures: railway and urban streets. The method also used the concept of vertical equity proposed by Litman in 2002 to identify possible inequities regarding demographic data in the surroundings of the distinct classes of the quality of pedestrian crossings for both transport barriers. 


\section{METHOD}

In this Chapter, we propose an analytical approach to assess community severance based on the classification of the quality of pedestrian crossings on two different types of transport infrastructures: a railway and urban streets. The method is also used to identify possible inequities regarding demographic data in the surroundings of the distinct classes of quality of pedestrian crossings for both infrastructures.

Chapter 3 is divided into four Sections. The first Section indicates the data required by the proposed approach and where they can be obtained. The second Section describes the analysis procedures for the assessment of community severance resulting from two types of transport barriers. In the third Section, we present the statistical analysis techniques used, whereas the final Section contains a summary of the method.

\subsection{Data collection}

The method developed for the analysis of the community severance caused by transport barriers in a medium-sized city is described in detail in Section 3.2. In general, the analysis procedures that comprise the method, for both transport infrastructures, include: data collection, characterization and classification of transport barriers, delineation of the area of influence, estimate of the population nearby the transport barriers, statistical analysis and vertical equity analysis.

The collected data is used in the analysis procedures related to the characterization of the transport barriers and the estimate of the population nearby them. The characterization of the transport barriers is based on the evaluation of a set of criteria relevant to the particularities of each barrier (detailed in Table 3.2 and Table 3.3). On the other hand, the estimate of the population depends on the availability and level of aggregation of the variables of interest.

Concerning the railway characterization, data on pedestrian infrastructure, safety and maintenance conditions are required, whereas for urban streets characterization, data on geometric design, pedestrian infrastructures, safety, population, maintenance conditions and land use are needed. These data can be obtained by field surveys, internet searches for open data and formal requests to the City Hall or competent bodies. In Table 3.1, we provide a summary of the necessary data for the characterization of the distinct transport barriers, as well as an indication of possible data sources. 
Table 3.1 - Summary of the necessary data for the characterization of transport barriers

\begin{tabular}{lccc}
\hline \multicolumn{1}{c}{ Data } & Railways & Urban streets & Source \\
\hline Geometric design & & $\mathrm{x}$ & $\begin{array}{c}\text { Field survey or combined images of Google } \\
\text { Street View and Google Maps }\end{array}$ \\
\hline Pedestrian infrastructures & $\mathrm{x}$ & $\mathrm{x}$ & $\begin{array}{c}\text { Field survey or combined images of Google } \\
\text { Street View and Google Maps }\end{array}$ \\
\hline Safety & $\mathrm{x}$ & $\mathrm{x}$ & City Hall or competent body \\
\hline Population & $\mathrm{x}$ & $\mathrm{x}$ & $\begin{array}{c}\text { Demographic census, questionnaires or interviews } \\
\text { Maintenance conditions }\end{array}$ \\
\hline Land use & $\mathrm{x}$ & $\mathrm{x}$ & $\begin{array}{c}\text { Street View and Google Maps, } \\
\text { City Hall or competent body }\end{array}$ \\
\hline Traffic volume & $\mathrm{x}$ & $\mathrm{x}$ & Field survey, City Hall or competent body \\
\hline Source: The auther
\end{tabular}

Source: The author

Population data should be as disaggregate as possible, in order to capture a more accurate and actual profile of the inhabitants. This can be obtained through questionnaires or interviews. However, due to unavailability of data, scarcity of financial resources, professional support or time, census data can also be used.

In addition, to locate the railway and create the urban street network, we recommend using open geographic information systems, such as the geographic database from Open Street Map or Google Maps.

\subsection{Analysis procedures}

The proposal for the assessment of community severance is based on measuring and classifying the quality of pedestrian crossings on two different types of transport barriers. Afterwards, possible inequities are identified by estimating the number of inhabitants that have particular demographic characteristics in areas close to the railway and urban streets of different classes of quality.

\subsubsection{Assessment of community severance caused by a Railway}

Railway infrastructures within the urban perimeter of cities comprise physical barriers to pedestrian mobility, since the physical segregation of the infrastructure is practically unavoidable, and passages are only possible in the specific points where there are railroad crossings. Therefore, we propose a concise method for the assessment of the community severance caused by a railway, with the following procedures: data collection (Subsection 3.1), characterization of the railroad crossings and segments without railroad crossings, classification, delineation of the area of influence, estimate of the population nearby the railroad 
crossings and segments without railroad crossings, statistical analysis and vertical equity analysis.

The characterization of the railway is performed using field surveys, in which the railroad crossings and the segments without railroad crossings are qualitatively analyzed. The field survey must be carried out by a specialist in the area of urban and transportation planning and it does not consider informal crossings.

The qualitative evaluation of the distinct types of railroad crossings and segments without railroad crossings is based on a different and appropriate set of criteria for each facility, as indicated in Table 3.2. Moreover, the criteria selection was based on the Railway Service Instructions of the National Department of Transport Infrastructure (or DNIT, which in Portuguese stands for Departamento Nacional de Infraestrutura de Transportes) (DNIT, 2015a, 2015b, 2015c, 2015d, 2015e).

Table 3.2 - Set of criteria assessed for the distinct types of railroad crossings and segments without railroad crossings (continued)

\begin{tabular}{|c|c|c|}
\hline Criterion & Description & Category (score) \\
\hline Traffic volume & $\begin{array}{l}\text { number of railway compositions per hour (in the peak- } \\
\text { hour) }\end{array}$ & $\begin{array}{l}\text { low }(1.00) \text {; regular }(0.50) \text {; } \\
\text { high }(0.00)\end{array}$ \\
\hline \multicolumn{3}{|c|}{ Level Crossings (LC) } \\
\hline $\begin{array}{l}\text { Pavement } \\
\text { conservation } \\
\text { conditions }\end{array}$ & $\begin{array}{l}\text { pavement conservation conditions of the urban street } \\
\text { segment located within a } 40 \text {-meters band from the railway } \\
\text { line, near the level crossing }\end{array}$ & $\begin{array}{l}\text { regular }(1.00) ; \text { irregular } \\
(0.50) ; \text { nonexistent }(0.00)\end{array}$ \\
\hline Rail uniformity & $\begin{array}{l}\text { pavement conservation conditions between the rails of the } \\
\text { level crossing and rail uniformity conditions }\end{array}$ & $\begin{array}{l}\text { regular }(1.00) \text {; irregular } \\
(0.50) ; \text { nonexistent }(0.00)\end{array}$ \\
\hline Lighting efficiency & $\begin{array}{l}\text { lighting near the level crossing stands out from the urban } \\
\text { street, emphasizing the existing signs and the LC }\end{array}$ & $\begin{array}{l}\text { efficient }(1.00) \text {; insufficient } \\
(0.50) ; \text { nonexistent }(0.00)\end{array}$ \\
\hline $\begin{array}{c}\text { Pedestrian } \\
\text { walkway width }^{1}\end{array}$ & $\begin{array}{l}\text { a suitable pedestrian walkway width should be equal or } \\
\text { greater than } 1.50 \mathrm{~m}\end{array}$ & $\begin{array}{l}\text { suitable }(1.00) \text {; unsuitable } \\
(0.50) \text {; nonexistent }(0.00)\end{array}$ \\
\hline Relief conditions & $\begin{array}{l}\text { influence of the relief around the railway in the view of } \\
\text { the urban street drivers }\end{array}$ & $\begin{array}{l}\text { flat }(1.00) \text {; corrugated }(0.50) \text {; } \\
\text { mountainous }(0.00)\end{array}$ \\
\hline $\begin{array}{l}\text { Efficiency of the } \\
\text { existing signs }\end{array}$ & $\begin{array}{l}\text { the efficiency of the existing signaling in alerting } \\
\text { pedestrians and drivers about the proximity of the LC }\end{array}$ & $\begin{array}{l}\text { efficient }(1.00) ; \text { insufficient } \\
(0.50) ; \text { nonexistent }(0.00)\end{array}$ \\
\hline Salubrity & intensity of the presence of garbage and vegetation & $\begin{array}{l}\text { good }(1.00) ; \text { regular }(0.50) \\
\text { poor }(0.00)\end{array}$ \\
\hline Influence limit $^{2}$ & $\begin{array}{l}\text { level crossing should be outside the limit of influence of } \\
\text { other types of crossings }\end{array}$ & $\begin{array}{l}\text { suitable (1.00); unsuitable } \\
(0.00)\end{array}$ \\
\hline \multicolumn{3}{|c|}{ Underpasses (UP) } \\
\hline $\begin{array}{l}\text { Lighting efficiency } \\
\text { during the day }\end{array}$ & $\begin{array}{l}\text { lighting efficiency during the day allows a wide field of } \\
\text { vision }\end{array}$ & $\begin{array}{l}\text { efficient }(1.00) \text {; insufficient } \\
(0.50) \text {; nonexistent }(0.00)\end{array}$ \\
\hline $\begin{array}{l}\text { Lighting efficiency } \\
\text { at night }\end{array}$ & lighting efficiency at night allows a wide field of vision & $\begin{array}{l}\text { efficient }(1.00) \text {; insufficient } \\
(0.50) ; \text { nonexistent }(0.00)\end{array}$ \\
\hline $\begin{array}{l}\text { Pedestrian } \\
\text { walkway width }{ }^{1}\end{array}$ & $\begin{array}{l}\text { a suitable pedestrian walkway width should be equal or } \\
\text { greater than } 1.50 \mathrm{~m}\end{array}$ & $\begin{array}{l}\text { suitable }(1.00) \text {; unsuitable } \\
(0.50) \text {; nonexistent }(0.00)\end{array}$ \\
\hline
\end{tabular}


Table 3.2 - Set of criteria assessed for the distinct types of railroad crossings and segments without railroad crossings (conclusion)

\begin{tabular}{|c|c|c|}
\hline Criterion & Description & Category (score) \\
\hline \multicolumn{3}{|c|}{ Underpasses (UP) } \\
\hline $\begin{array}{l}\text { Height of } \\
\text { Guardrail }^{1}\end{array}$ & $\begin{array}{l}\text { a suitable height of guardrail should be equal or greater } \\
\text { than } 1.00 \mathrm{~m}\end{array}$ & $\begin{array}{l}\text { suitable }(1.00) \text {; unsuitable } \\
(0.50) \text {; nonexistent }(0.00)\end{array}$ \\
\hline Salubrity & intensity of the presence of garbage and vegetation & $\begin{array}{l}\text { good }(1.00) \text {; regular }(0.50) \text {; } \\
\text { poor }(0.00)\end{array}$ \\
\hline \multicolumn{3}{|c|}{ Overpasses (OP) } \\
\hline $\begin{array}{c}\text { Location } \\
\text { attractiveness }\end{array}$ & $\begin{array}{l}\text { the location of the railroad crossing favors the attraction } \\
\text { of the main pedestrian flow }\end{array}$ & $\begin{array}{l}\text { suitable (1.00); unsuitable } \\
(0.00)\end{array}$ \\
\hline $\begin{array}{c}\text { Pedestrian } \\
\text { walkway width }^{1}\end{array}$ & $\begin{array}{l}\text { a suitable pedestrian walkway width should be equal or } \\
\text { greater than } 1.50 \mathrm{~m}\end{array}$ & $\begin{array}{l}\text { suitable (1.00); unsuitable } \\
(0.00)\end{array}$ \\
\hline $\begin{array}{l}\text { Height of } \\
\text { guardrail }^{1}\end{array}$ & $\begin{array}{l}\text { a suitable height of guardrail should be equal or greater } \\
\text { than } 1.00 \mathrm{~m}\end{array}$ & $\begin{array}{l}\text { suitable }(1.00) \text {; unsuitable } \\
(0.50) \text {; nonexistent }(0.00)\end{array}$ \\
\hline $\begin{array}{l}\text { Existence of } \\
\text { coverage }\end{array}$ & $\begin{array}{l}\text { existence of coverage to protect users from adverse } \\
\text { weather conditions }\end{array}$ & $\begin{array}{l}\text { existent (1.00); nonexistent } \\
(0.00)\end{array}$ \\
\hline Lighting efficiency & $\begin{array}{l}\text { the lighting is well distributed along the walkway, } \\
\text { allowing a wide field of vision }\end{array}$ & $\begin{array}{l}\text { efficient }(1.00) \text {; insufficient } \\
(0.50) \text {; nonexistent }(0.00)\end{array}$ \\
\hline Salubrity & intensity of the presence of garbage and vegetation & $\begin{array}{l}\text { good }(1.00) \text {; regular }(0.50) \text {; } \\
\text { poor }(0.00)\end{array}$ \\
\hline \multicolumn{3}{|c|}{ Pedestrian Crossings (PC) } \\
\hline Rail uniformity & $\begin{array}{l}\text { pavement conservation conditions between the rails of the } \\
\text { level crossing and rail uniformity conditions }\end{array}$ & $\begin{array}{l}\text { regular }(1.00) \text {; irregular } \\
(0.50) ; \text { nonexistent }(0.00)\end{array}$ \\
\hline Lighting efficiency & $\begin{array}{l}\text { lighting near the pedestrian crossing stands out from the } \\
\text { urban street, emphasizing the existing signaling and the } \\
\text { LC }\end{array}$ & $\begin{array}{l}\text { efficient }(1.00) \text {; insufficient } \\
(0.50) \text {; nonexistent }(0.00)\end{array}$ \\
\hline Crossing width ${ }^{1}$ & $\begin{array}{l}\text { a suitable pedestrian crossing width should be equal or } \\
\text { greater than } 1.50 \mathrm{~m}\end{array}$ & $\begin{array}{l}\text { suitable (1.00); unsuitable } \\
(0.00)\end{array}$ \\
\hline $\begin{array}{l}\text { Efficiency of the } \\
\text { existing signs }\end{array}$ & $\begin{array}{l}\text { the efficiency of the existing signaling in alerting } \\
\text { pedestrians and drivers about the proximity of the train }\end{array}$ & $\begin{array}{l}\text { efficient }(1.00) \text {; insufficient } \\
(0.50) \text {; nonexistent }(0.00)\end{array}$ \\
\hline Salubrity & intensity of the presence of garbage and vegetation & $\begin{array}{l}\text { good }(1.00) \text {; regular }(0.50) \text {; } \\
\text { poor }(0.00)\end{array}$ \\
\hline \multicolumn{3}{|c|}{ Segment Without Crossings (SWC) } \\
\hline $\begin{array}{c}\text { Type of barrier } \\
\text { material }\end{array}$ & $\begin{array}{l}\text { influence of the permeability of the barrier material on the } \\
\text { crossing }\end{array}$ & $\begin{array}{l}\text { facilitates }(1.00) \text {; hampers } \\
(0.50) ; \text { blocks }(0.00)\end{array}$ \\
\hline Barrier height & influence of the barrier height on the crossing & $\begin{array}{l}\text { facilitates }(1.00) \text {; hampers } \\
(0.50) \text {; blocks }(0.00)\end{array}$ \\
\hline $\begin{array}{l}\text { Efficiency of the } \\
\text { existing signs }\end{array}$ & $\begin{array}{l}\text { efficiency of the existing signaling in alerting pedestrians } \\
\text { and drivers about the proximity of the train }\end{array}$ & $\begin{array}{l}\text { efficient }(1.00) \text {; insufficient } \\
(0.50) \text {; nonexistent }(0.00)\end{array}$ \\
\hline Railway proximity & $\begin{array}{l}\text { according to Law No. } 10,932 / 2004 \text {, a non-buildable band } \\
\text { of } 15 \text { meters from both sides of the railway is mandatory }\end{array}$ & $\begin{array}{l}\text { suitable (1.00); unsuitable } \\
(0.00)\end{array}$ \\
\hline Salubrity & intensity of the presence of garbage and vegetation & $\begin{array}{l}\text { good }(1.00) \text {; regular }(0.50) ; \\
\text { poor }(0.00)\end{array}$ \\
\hline Safety & $\begin{array}{l}\text { annual crime rate per } 1000 \text { inhabitants combined with the } \\
\text { annual death rate per } 1000 \text { inhabitants }\end{array}$ & $\begin{array}{l}\text { low }(1.00) \text {; regular }(0.50) \text {; } \\
\text { high }(0.00)\end{array}$ \\
\hline
\end{tabular}

1 According to ABNT NBR 9050/2004

${ }^{2}$ According to ABNT NBR 15680/2017, level crossing should be 1500 meters away from another level crossing, 3000 meters away from an overpass and 500 meters away from a pedestrian crossing

Source: The author 
As presented in Table 3.2, the criteria evaluation of each type of railroad crossing and segment without railroad crossings receive scores ranging from 0 to 1 , in which score 0 is assigned to unfavorable conditions for urban mobility and score 1, to favorable conditions. According to the percentage of conformance for each set of criteria, the classification of the railroad crossings and segments without railroad crossings is performed following an ordinal scale of relevance ranging from A to D. Class A corresponds to the most favorable conditions for pedestrian urban mobility in the area of influence considered, and D, to the most unfavorable conditions.

For the delineation of the area of influence, a band of 500 meters is considered for the railway (highlighted in the example of Figure 3.1, in green). Within the band, the area of influence for each railroad crossing is also delimited, considering a 400 meters radius (highlighted in the example of Figure 3.1, in orange). In the case of overlapping areas of influence of the railroad crossings, Voronoi diagrams can be used, under the assumption that residents will tend to cross the railway through the nearest railway crossing (for details on the Voronoi diagram see Okabe, Boots, Sugihara, \& Chiu, 2009). The railway area of influence is slightly larger than the railroad crossings, because it was considered that people who live more than 400 meters away from a railroad crossing are as affected as those who live near the segments without railroad crossings.

Figure 3.1 - Example of areas of influence for the railroad crossings and railway

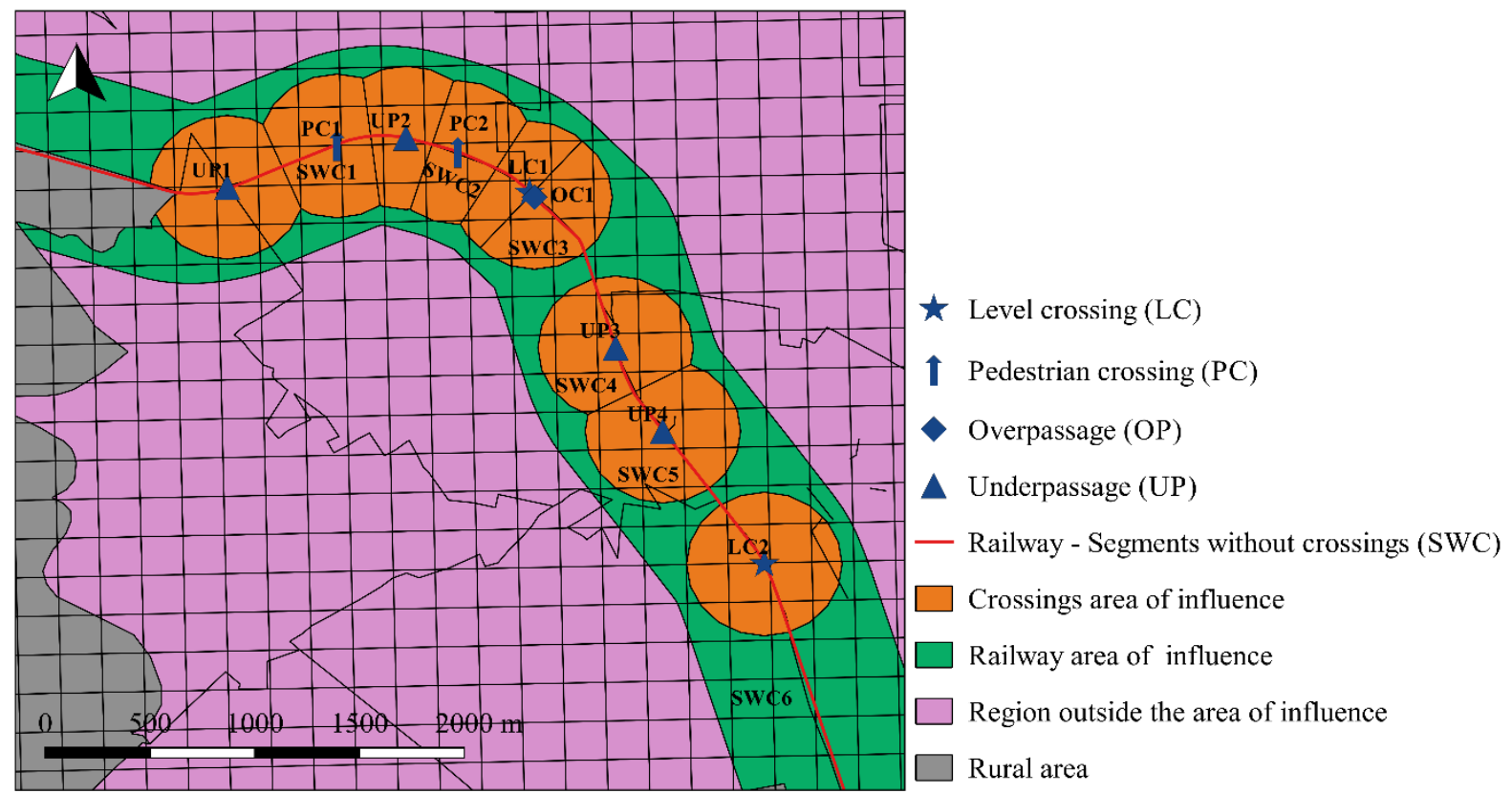

Source: The author 
Based on the population data collected, the characteristics of the railway (layout, railroad crossings and segments without railroad crossings) and the delimited areas of influence, the study area can be georeferenced using, for example, an open source GIS package, such as Quantum GIS. We propose the study of variables regarding the range of monthly nominal income, permanent mobility constraints, gender and age, however other variables related to population can also be considered.

If population data are highly aggregated, as in the case of weighting areas and census tracts, the estimate of the number of residents is carried out using adjustment factors. Weighting areas constitute geographical partitions formed by a mutually exclusive group of areas that follow technical restrictions concerning contiguity and size defined by the Brazilian Institute of Geography and Statistics (or IBGE, which in Portuguese stands for Instituto Brasileiro de Geografia e Estatística). The adjustment factors will be based on the population distribution provided by the aggregated data, which are multiplied by the number of inhabitants given in the statistical grid (less aggregated data). The statistical grid comprises a system of regular cells arranged in grid form. Urban regions have dimension cells equal to $200 \mathrm{~m}$ x $200 \mathrm{~m}$ (IBGE, 2016). In the case of the variable gender, this approach is not necessary, since gender is provided directly by the statistical grid.

Each variable has a number of factors equivalent to the number of categories (e.g., permanent mobility constraints have 4 categories - disability, great difficulty, some difficulty and no disability - and, therefore, 4 factors) for each weighting area. Factors are then calculated from the probability of occurrence of the category in the weighting area. Thus, the population is estimated according to its demographic characteristics, for each cell of the statistical grid. Therefore, the variability of the distribution of the estimated population is based on the distribution of the statistical grid, mitigating the limitations resulting from the highly aggregated data.

Hence, through the crossover of the population information (for example, by range of monthly nominal income, self-declared permanent mobility constraints, gender and age range) with the influence areas of the railroad crossings and the railway, the number of residents in the areas of interest can be computed.

From these values, an exploratory data analysis can show relevant aspects about the residents alongside the railway. Hypotheses regarding the variable of classification can then be formulated and tested with chi-square $\left(\chi^{2}\right)$ tests of independence and standardized Pearson residuals (further detailed in Subsection 3.3) in relation to the following variables: (i) number of residents by range of monthly nominal income; (ii) number of residents with self-declared 
permanent mobility constraints; (iii) number of residents by gender and (iv) number of residents by age range.

Thereby, we identify deficits and excesses of residents in the surrounding regions of the railroad crossings and segments without railroad crossings, thus identifying equity issues in the distribution of the number of residents along the railway and in the distinct types of railroad crossings.

\subsubsection{Assessment of community severance caused by Urban Streets}

Urban streets constitute physical barriers to pedestrian urban mobility, not only because of the street infrastructure but also because of their traffic stream volume and speeds. The characterizations of these barriers are performed using open and census data, combined images of Google Street View and Google Maps, Quantum GIS v.3.4.6 software and IBM SPSS Statistics v.25 software. The procedures of the proposed method are summarized in Figure 3.2.

Figure 3.2 - Overview of the method

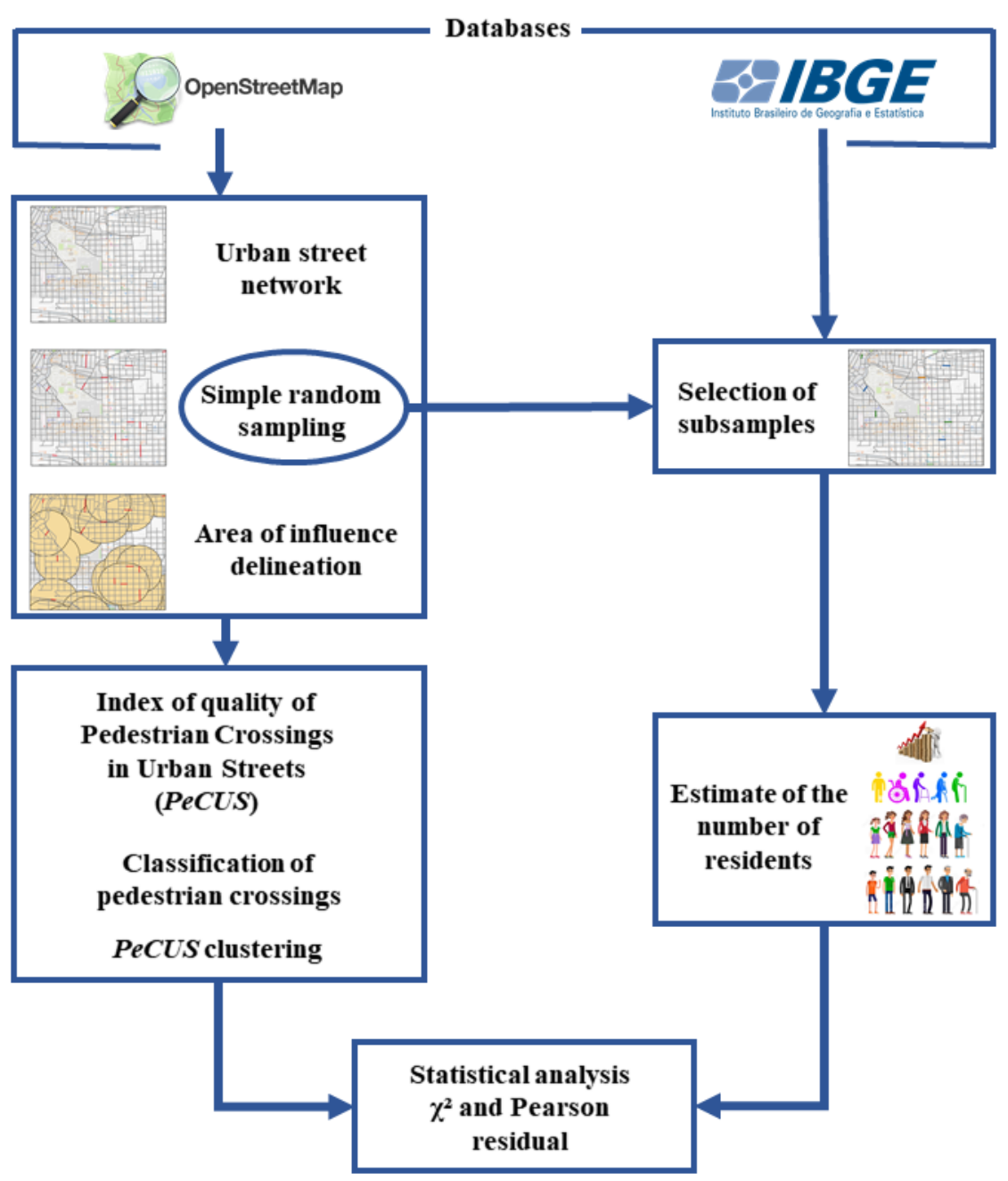

Source: The author 
The urban street network map can be generated using the Open Street Map (OSM) database and the free software package Quantum GIS. Unpaved streets, private streets, parking lots, railways and streams are not included in the map. Then, with the urban street network map containing only public urban streets, we selected a sample of urban streets by simple random sampling. The sample size must be determined considering a confidence level and a margin of error that ensure the statistical representation of the analysis.

A band of 400 meters is defined as the area of influence nearby the selected streets (Figure 3.3). The band area is used for classifying pedestrian crossings on urban streets (e.g. number of crimes and deaths, number of inhabitants) and for estimating the demographic characteristics of residents in the streets' surroundings.

Figure 3.3 - Example of area of influence for the randomly selected urban streets

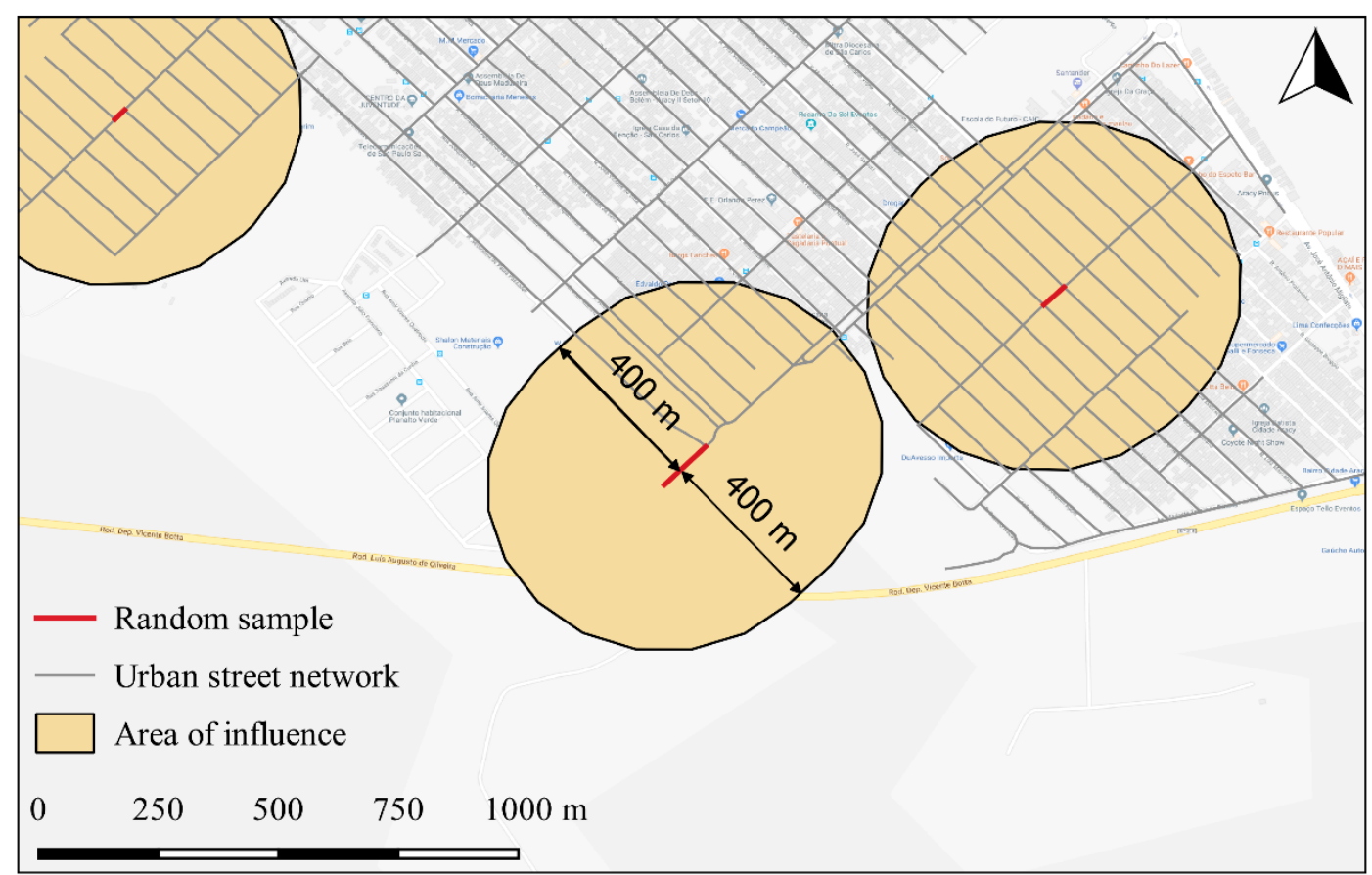

Source: The author

The classification of pedestrian crossings is based on fourteen criteria (Table 3.3) related to: the geometric design of the streets, available pedestrian infrastructures, population within the selected 400-meter band, safety and maintenance conditions, as well as land use. For each criterion, score values ranging from 0 to 1 are assigned. Score 0 corresponds to the worst mobility conditions for pedestrians and score 1 to the best conditions, as indicated in Table 3.3. 
Table 3.3 - Summary of the criteria assessed for classifying pedestrian crossings on urban streets

\begin{tabular}{|c|c|c|c|}
\hline & Criterion & Description & Category (score) \\
\hline \multicolumn{2}{|c|}{ Traffic volume } & $\begin{array}{l}\text { number of vehicles (passenger car } \\
\text { equivalent - pce) per hour (in the } \\
\text { peak-hour) }\end{array}$ & $\begin{array}{l}\text { very low }(1.00) \text {; low }(0.75) \text {; regular }(0.50) \text {; } \\
\text { high }(0.25) \text {; very high }(0.00)\end{array}$ \\
\hline \multirow{3}{*}{ 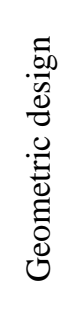 } & $\begin{array}{l}\text { Functional } \\
\text { classification }\end{array}$ & $\begin{array}{l}\text { urban street functional classification } \\
\text { (DNIT 2010) }\end{array}$ & $\begin{array}{l}\text { local }(1.00) \text {; collector }(0.67) \text {; secondary arterial } \\
(0.33) \text {; primary arterial }(0.00)\end{array}$ \\
\hline & $\begin{array}{l}\text { Traffic } \\
\text { direction }\end{array}$ & one-way or two-way direction & one-way (1.00); two-way (0.00) \\
\hline & $\begin{array}{l}\text { Number of } \\
\text { lanes }\end{array}$ & number of lanes per direction & $1(1.00) ; 2(0.67) ; 3(0.33) ; 4$ or more $(0.00)$ \\
\hline \multirow{6}{*}{ 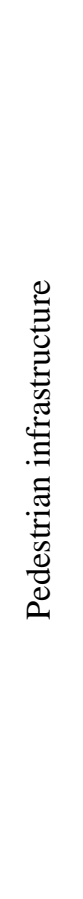 } & $\begin{array}{c}\text { Zebra } \\
\text { crossing }\end{array}$ & presence and type of zebra crossing & raised $(1.00)$; at level $(0.50)$; absence $(0.00)$ \\
\hline & $\begin{array}{l}\text { Zebra crossing } \\
\text { location }\end{array}$ & $\begin{array}{l}\text { attractiveness of the zebra crossing } \\
\text { location }\end{array}$ & $\begin{array}{l}\text { very attractive }(1.00) \text {; attractive }(0.67) \text {; not } \\
\text { attractive }(0.33) \text {; absence of zebra crossing } \\
(0.00)\end{array}$ \\
\hline & $\begin{array}{l}\text { Pedestrian } \\
\text { visibility }\end{array}$ & $\begin{array}{l}\text { driver's pedestrian visibility at } \\
\text { intersections }\end{array}$ & $\begin{array}{l}\text { total }(1.00) \text {; moderate }(0.75) \text {; regular }(0.50) \text {; } \\
\text { poor }(0.25) \text {; none }(0.00)\end{array}$ \\
\hline & Mandatory stop & $\begin{array}{l}\text { presence of vertical and/or } \\
\text { horizontal "STOP" signs at } \\
\text { intersections or presence of traffic } \\
\text { lights }\end{array}$ & $\begin{array}{l}\text { two-phase traffic light (1.00); three-phase } \\
\text { traffic light }(0.80) \text {; vertical and horizontal } \\
\text { "STOP" signs }(0.60) \text {; vertical "STOP" signs } \\
(0.40) \text {; horizontal "STOP" signs }(0.20) \text {; } \\
\text { absence }(0.00)\end{array}$ \\
\hline & Median & $\begin{array}{l}\text { presence of median strip and } \\
\text { pedestrian accommodation } \\
\text { possibility in the median strip }\end{array}$ & $\begin{array}{l}\text { allow pedestrian accommodation (1.00); do not } \\
\text { allow pedestrian accommodation }(0.50) \text {; } \\
\text { absence }(0.00)\end{array}$ \\
\hline & Accessibility & $\begin{array}{l}\text { presence and maintenance } \\
\text { conditions of curb ramps on both } \\
\text { sides of the pedestrian crossing }\end{array}$ & $\begin{array}{l}\text { excellent }(1.00) \text {; good }(0.80) \text {; regular }(0.60) \text {; } \\
\text { poor }(0.40) \text {; very poor }(0.20) \text {; absence }(0.00)\end{array}$ \\
\hline 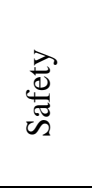 & $\begin{array}{l}\text { Number of } \\
\text { crimes and } \\
\text { deaths }\end{array}$ & $\begin{array}{l}\text { annual crime rate per } 1000 \\
\text { inhabitants combined with the } \\
\text { annual death rate per } 1000 \\
\text { inhabitants }\end{array}$ & $\begin{array}{l}\text { very low }(1.00) \text {; low }(0.75) \text {; regular }(0.50) \text {; } \\
\text { high }(0.25) \text {; very high }(0.00)\end{array}$ \\
\hline 竞. & $\begin{array}{l}\text { Number of } \\
\text { inhabitants }\end{array}$ & $\begin{array}{l}\text { number of inhabitants within the } \\
\text { 400-meter band }\end{array}$ & $\begin{array}{l}\text { regular }(1.00) \text {; high }(0.75) \text {; very high }(0.5) \text {; low } \\
(0.25) \text {; very low }(0.00)\end{array}$ \\
\hline \multirow{2}{*}{ 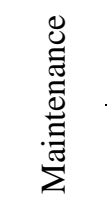 } & $\begin{array}{l}\text { Public } \\
\text { lighting }\end{array}$ & quality of public lampposts ${ }^{1}$ & $\begin{array}{l}\text { excellent }(1.00) \text {; good }(0.80) \text {; regular }(0.60) \text {; } \\
\text { poor }(0.40) \text {; very poor }(0.20) \text {; absence }(0.00)\end{array}$ \\
\hline & Salubrity & $\begin{array}{l}\text { intensity of the presence of garbage } \\
\text { and vegetation }\end{array}$ & $\begin{array}{l}\text { excellent }(1.00) \text {; good }(0.75) \text {; regular }(0.50) \text {; } \\
\text { poor }(0.25) \text {; very poor }(0.00)\end{array}$ \\
\hline 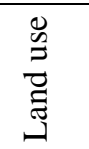 & Land use & $\begin{array}{l}\text { land use }{ }^{1} \text { around the selected urban } \\
\text { street }\end{array}$ & $\begin{array}{l}\text { commercial (1.00); mixed land use - } \\
\text { commercial and residential }(0.75) \text {; residential } \\
(0.50) \text {; institutional }(0.25) \text {; industrial }(0.00)\end{array}$ \\
\hline
\end{tabular}

${ }^{1}$ Provided by the City Hall or competent body

Source: The author 
Criteria related to geometric design, pedestrian infrastructure, and maintenance conditions are evaluated by analyzing the combined images of Google Street View and Google Maps. The assessment of the criterion: functional classification, traffic direction, number of lanes, zebra crossings, zebra crossings location, pedestrian visibility, median and salubrity are described in Table 3.3. However, the criteria: mandatory stop, accessibility and public lighting needs more explanation.

Segments of urban streets correspond to the stretches between intersections, as shown in Figure 3.4(a). For the calculation of the mandatory stop criterion, we evaluate two points that correspond to the two intersections of the segment, as indicated in Figure 3.4(b). In this criterion the presence of vertical and/or horizontal "STOP" signs or presence of traffic lights at the intersections are scored according to Table 3.3. The final score corresponds to the average of the scores for the two points.

Figure 3.4 - Schematic drawing of the reference points analyzed in the segments of urban streets

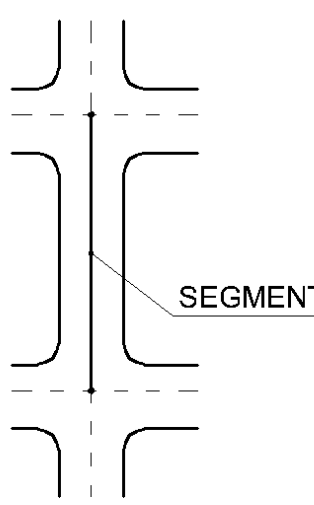

(a)

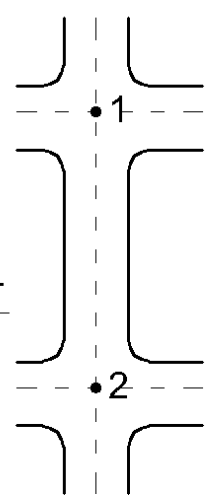

(b)

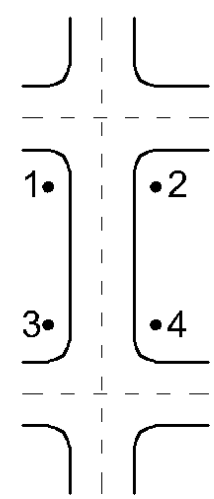

(c)

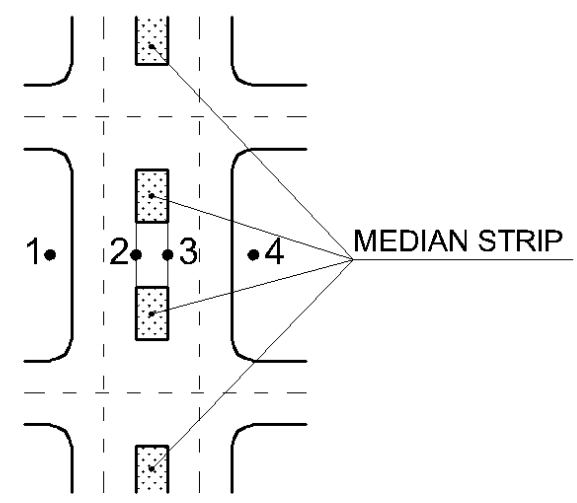

(d)

Source: The author

Concerning the accessibility criterion, four points near the intersections of the segment are evaluated, as illustrated in Figure 3.4(c), in the case of the presence of a median strip the reference points are considered according to the schematic drawing in Figure 3.4(d). We considered that an accessible crossing occurs when the sidewalks have curb ramps on both sides of the crossing. Thus, if only one side of the sidewalk has a curb ramp, score 0 is assigned for the pair of points. If both sides have curb ramps, their scores are assigned according to their maintenance conditions, as indicated in Table 3.3. Therefore, the final score corresponds to the average of the scores for the pair of points.

The public lighting criterion is assessed through the quality of the lampposts surrounding the segments. The location plan of the city lampposts and its specifications ought 
to be provided by the City Hall or competent body. The specifications detail the bracket type (short, long or medium), lamp-type (fluorescent, halogen, incandescent, led, mixed, Mercury vapors or Sodium vapor or metallic vapor), lamp power $(70 \mathrm{~W}, 80 \mathrm{~W}, 100 \mathrm{~W}, 125 \mathrm{~W}, 150 \mathrm{~W}$, $250 \mathrm{~W}$ or $400 \mathrm{~W}$ ) and luminaire type (open, closed, integrated or ornamental) of the city lampposts. Therefore, the final score corresponds to the combination of the lamppost specifications, as presented in Table 3.3.

On the other hand, the evaluation of the criterion concerning safety is carried out based on the annual crime and death rates per 1000 inhabitants within the area of influence of the urban street segments sampled, during a specified period.

Regarding the criterion related to population, the number of inhabitants from the area of influence is estimated and categorized into five levels. The scores assigned to the five levels of number of inhabitants (very high to very low) follow the concept that a neighborhood with an intermediary (regular) number of inhabitants favors pedestrian urban mobility. A high number of inhabitants in the neighborhood mostly attracts local trips, whereas a low number of inhabitants, may attract a greater number of trips (motorized or not), because generally in these places there are trip generation centers.

In addition, the scores assigned for the land use criterion are also analyzed considering the number of trips generated. Moreover, land use brings information about commercial, residential, mixed land use (commercial and residential), institutional and industrial zones, which enables a reading on the number of inhabitants, as well. Commercial zones have a higher number of attracted trips than residential zones, which encourages active trips, however this number reduces overnight. In residential, institutional and industrial zones the number of attracted trips is low. Besides that, institutional and industrial zones have a very low number of inhabitants and generally in these places there are no trip generation centers, which could inhibit active trips.

Thus, from the assessment of the criteria detailed, the classification of pedestrian crossings on urban streets is carried out. For the classification, each street is considered as an independent case. Therefore, the overlapping areas of influence do not affect the results.

The combination of criteria is defined as the PeCUS (Pedestrian Crossings on Urban Streets) index. As the total sum of scores varies according to the quality of crossings for pedestrians, the PeCUS index also reflects, but inversely, the variation of trip impedances and the access of pedestrians to goods and services (and by extension, the level of community severance). 
As indicated in Figure 3.2, a cluster analysis is conducted (detailed in Subsection 3.3) to group the PeCUS index results into six classes ranging from A to $\mathrm{F}$, using the IBM SPSS Statistics v. 25 software. Class A corresponds to the best quality of pedestrian crossings and F corresponds to the worst evaluation.

The sampled streets are then classified (from A to F) regarding the quality of pedestrian crossings. Next, the demographic characteristics of the residents in the streets' surroundings are examined. However, in order to look for evidence of associations between the variables through a chi-square $\left(\chi^{2}\right)$ test of independence, each unit of the sample must be counted only once, that is, each observed element must be allocated in only one cell of the contingency table. For this reason, overlapping areas of influence must be avoided and a selection of subsamples without overlapping areas of influence become necessary.

Three subsamples are randomly selected from the original sample in such a way that only the segments that have bands that do not overlap with the bands of the segments already chosen are kept in the subsample. The new subsamples are then used to estimate the number of residents within non-overlapping 400-meter bands regarding the variables of interest. As in the railway, in this method we propose the study of the variables regarding range of monthly nominal income, permanent mobility constraints, gender and age, however other variables related to the population could also be used.

If the population data are highly aggregated, as in the case of weighting areas and census tracts, the estimate of the number of residents is carried out using adjustment factors. These factors are based on the population distribution provided by the aggregated data, which are multiplied by the number of inhabitants given in the statistical grid (less aggregated data). Finally, in order to accept or reject the null hypothesis of independence between the variables $\left(\mathrm{H}_{0}\right)$ and to verify the degree of dependence between them, we use the chi-square $\left(\chi^{2}\right)$ test of independence and the squared Pearson residuals, as detailed in Subsection 3.3.

Thus, we identify deficits and excesses of residents' distribution in the surrounding regions of the urban streets, which may help to understand important equity issues.

\subsection{Statistical analysis}

The method presented for the assessment of the community severance caused by two different transport barriers uses statistical analysis techniques, such as: cluster analysis, chisquare $\left(\chi^{2}\right)$ test of independence and standardized Pearson residuals. In this Section, we briefly describe these statistical analysis techniques. 
The cluster analysis is used to group the PeCUS index results into classes of quality, using the IBM SPSS Statistics v.25 software. In addition, the chi-square $\left(\chi^{2}\right)$ test of independence and standardized Pearson residuals are used to investigate evidence of associations and the degree of dependence between the variables studied for both transport barriers.

\subsubsection{Cluster analysis}

Cluster analysis classifies objects (e.g., respondents, products, or other entities) on a set of user selected characteristics. The resulting clusters should exhibit high internal (withincluster) homogeneity and high external (between-cluster) heterogeneity. Thus, if the classification is successful, the objects within clusters will be close together when plotted geometrically, and different clusters will be far apart (Hair, Black, Babin, \& Anderson, 2010).

According to Hair et al. (2010), nonhierarchical clustering procedures assign objects into clusters once the number of clusters is specified. The nonhierarchical cluster software programs usually proceed through two steps:

a) Specify cluster seeds: the first step is to identify initial values or starting points, known as cluster seeds, for each cluster. In this study, cluster analysis is used for the urban street analysis. For the cluster seed identification, we based the number of classes on the six pedestrian levels of service (LOS) from the Highway Capacity Manual (2010), therefore we adopted a cluster seed equal to 6.

b) Assignment: with the cluster seeds defined, the next step is to assign each observation to one of the cluster seeds based on similarity. In this study, the most appropriate approach to do this assignment corresponds to the k-means algorithm.

$K$-means algorithms work by portioning the data into a user-specified number of clusters and then iteratively reassigning observations to clusters until some numerical criterion is met. The criterion specifies a goal related to minimizing the distance of observations from one another in a cluster and maximizing the distance between clusters (Hair et al., 2010).

\subsubsection{Chi-square $\left(\chi^{2}\right)$ test of independence and standardized Pearson residuals}

The chi-square $\left(\chi^{2}\right)$ test of independence is used in contingency tables built from the variables studied in order to accept or reject the hypothesis of independence between the variables $\left(\mathrm{H}_{0}\right)$. The value of the chi-square $\left(\chi^{2}\right)$ is calculated from the sum of the squared Pearson residual $\left(\mathrm{PR}^{2}\right)$ values, according to Equation 3.1. Therefore, the squared Pearson residual corresponds to the individual contribution of each cell to the chi-square $\left(\chi^{2}\right)$ value. 


$$
\chi^{2}=\sum P R^{2}=\frac{(\text { Observed-Expected })^{2}}{\text { Expected }}
$$

where $\chi^{2}$ corresponds to the chi-square value, $\sum P R^{2}$ indicates the summation of squared Pearson residuals, Observed corresponds to the observed count and Expected, corresponds to the expected count.

In addition to calculating the chi-square $\left(\chi^{2}\right)$ value and its corresponding $p$-value, we compute the standardized Pearson residuals (Equation 3.2), which allows a direct comparison between each cell of the contingency table. Thus, the chi-square $\left(\chi^{2}\right)$ test of independence is used to assess the evidence of association between the variables, whereas the standardized Pearson residuals are used to better understand the nature and the degree of dependence between the variables.

$$
S P R=\frac{\text { observed }- \text { Expected }}{\sqrt{\text { Expected } \cdot\left(1-\frac{\text { row }_{\text {total }}}{\text { Total }}\right) \cdot\left(1-\frac{\text { column }}{\text { total }}\right)}}
$$

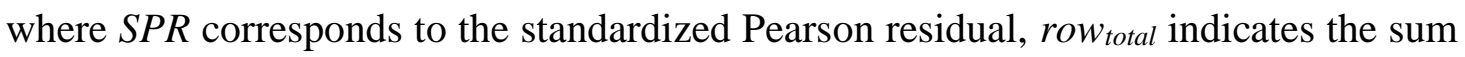
of the observed counts in the row, and column total indicates the sum of the observed counts in the column and Total indicates the sum of all observed counts.

A standardized Pearson residual that exceeds about 2 indicates that the cell greatly contributes to the chi-square $\left(\chi^{2}\right)$ value and does not fit the $\mathrm{H}_{0}$. Larger values are more relevant when the degrees of freedom are larger, and it becomes more likely that at least one is larger simply by chance (Agresti, 2018).

\subsection{Summary of the proposed method}

The method proposed for the assessment of community severance caused by a railway and urban streets is summarized in Table 3.4.

As presented in Table 3.4, there are some differences between the classification criteria and scale of the railway and urban streets. For the railway, the criteria are not equal for all railway crossings and segments without railway crossings, because those facilities have different characteristics that must be differently and properly evaluated. However, urban streets have similar characteristics that allow a unified evaluation, and for this reason, the creation of an index, capable of measuring the variation of the quality of pedestrian crossings on urban streets (PeCUS index) is possible. 
Table 3.4 - Summary of the method applied for the assessment of community severance caused by both transport barriers

\begin{tabular}{|c|c|c|c|}
\hline & & Railway & Urban streets \\
\hline \multicolumn{2}{|c|}{ Databases } & $\begin{array}{l}\text { open data, population data as disaggregated } \\
\text { as possible, however highly aggregated } \\
\text { data (census data) can also be used }\end{array}$ & $\begin{array}{l}\text { open data, population data as disaggregated } \\
\text { as possible, however highly aggregated } \\
\text { data (census data) can also be used }\end{array}$ \\
\hline \multirow{6}{*}{ 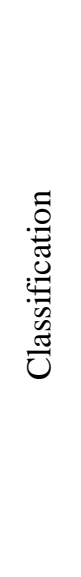 } & \multirow{5}{*}{ Criteria } & different for each type of crossing & equal for all crossings \\
\hline & & $\begin{array}{l}\text { number of criteria evaluated ranges from } 5 \\
\text { to } 6\end{array}$ & $\begin{array}{l}\text { number of criteria evaluated corresponds to } \\
14\end{array}$ \\
\hline & & scores range from 1 to 3 & scores range from 0 to 1 \\
\hline & & \multirow{2}{*}{$\begin{array}{l}\text { related to pedestrian infrastructure and } \\
\text { maintenance }\end{array}$} & $\begin{array}{l}\text { related to geometric design, pedestrian } \\
\text { infrastructure, safety, population, } \\
\text { maintenance and land use }\end{array}$ \\
\hline & & & $\begin{array}{l}\text { creation of the index of quality of } \\
\text { Pedestrian Crossings on Urban Streets } \\
\text { (PeCUS index) }\end{array}$ \\
\hline & Scale & groups were divided by $\%$ of conformance & groups were divided by cluster analysis \\
\hline \multirow{2}{*}{\multicolumn{2}{|c|}{ Area of influence }} & $\begin{array}{l}\text { band of } 500 \text { meters for the railway line and } \\
400 \text { meters radius for the railroad crossings }\end{array}$ & $\begin{array}{l}\text { band of } 400 \text { meters nearby the selected } \\
\text { urban streets }\end{array}$ \\
\hline & & $\begin{array}{l}\text { overlapping areas of influence are avoided } \\
\text { by computing a Voronoi diagram }\end{array}$ & $\begin{array}{l}\text { overlapping areas of influence are avoided } \\
\text { by selecting three new subsamples }\end{array}$ \\
\hline \multirow{4}{*}{ 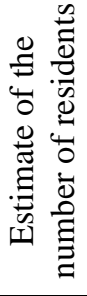 } & Income & \multirow{4}{*}{$\begin{array}{l}\text { preferably computed in a disaggregated } \\
\text { level, but the use of census data (highly } \\
\text { aggregated) is also possible. In this case, } \\
\text { factors based on the population distribution } \\
\text { provided by the aggregated data are } \\
\text { multiplied by the number of inhabitants } \\
\text { given in the statistical grid }\end{array}$} & \multirow{4}{*}{$\begin{array}{l}\text { preferably computed in a disaggregated } \\
\text { level, but the use of census data (highly } \\
\text { aggregated) is also possible. In this case, } \\
\text { factors based on the population distribution } \\
\text { provided by the aggregated data are } \\
\text { multiplied by the number of inhabitants } \\
\text { given in the statistical grid }\end{array}$} \\
\hline & $\begin{array}{l}\text { Permanent } \\
\text { mobility } \\
\text { constraints }\end{array}$ & & \\
\hline & Age range & & \\
\hline & Gender & & \\
\hline \multicolumn{2}{|c|}{$\begin{array}{l}\text { Exploratory data } \\
\text { analysis }\end{array}$} & $\begin{array}{l}\text { outline conjectures about the residents } \\
\text { alongside the railway regarding the } \\
\text { variables studied }\end{array}$ & $\begin{array}{l}\text { outline conjectures about the residents } \\
\text { alongside the urban streets regarding the } \\
\text { variables studied }\end{array}$ \\
\hline \multicolumn{2}{|c|}{$\begin{array}{l}\text { Chi-square }\left(\chi^{2}\right) \text { test } \\
\text { of independence }\end{array}$} & $\begin{array}{l}\text { used to investigate evidence of associations } \\
\text { between the variables studied }\end{array}$ & $\begin{array}{l}\text { used to investigate evidence of associations } \\
\text { between the variables studied }\end{array}$ \\
\hline \multicolumn{2}{|c|}{$\begin{array}{l}\text { Standardized } \\
\text { Pearson residuals }\end{array}$} & $\begin{array}{l}\text { used to investigate the degree of } \\
\text { dependence between the variables studied }\end{array}$ & $\begin{array}{l}\text { used to investigate the degree of } \\
\text { dependence between the variables studied }\end{array}$ \\
\hline \multicolumn{2}{|c|}{ Vertical equity } & $\begin{array}{l}\text { deficits and excesses of residents regarding } \\
\text { the variables studied are identified in the } \\
\text { surrounding regions of the railroad } \\
\text { crossings and segments without railroad } \\
\text { crossings }\end{array}$ & $\begin{array}{l}\text { deficits and excesses of residents regarding } \\
\text { the variables studied are identified in the } \\
\text { surrounding regions of the crossings }\end{array}$ \\
\hline
\end{tabular}

Source: The author

The area of influence regarding the railway line and urban streets is defined as a band of 400 meters. The railway area of influence is slightly larger than the railroad crossings, because it was considered that people who live more than 400 meters away from a railroad crossing are as affected as those who live near the segments without railroad crossings. 
In relation to the estimate of the number of residents for both infrastructures, it is preferable to be computed at a disaggregated level, but the use of census data (spatially aggregated) is also possible. In this case, factors based on the population distribution provided by the aggregated data are multiplied by the number of inhabitants given in the statistical grid.

Concerning the exploratory data analysis, chi-square $\left(\chi^{2}\right)$ test of independence, standardized Pearson residuals and vertical equity, the method used for both transport barriers has no difference.

From the summary and the comparison of the method proposed for both railway and urban streets, we prepared a concise description of the analytical procedures that constitute the method, as indicated in Table 3.5 and illustrated in the flow diagram of Figure 3.5.

Table 3.5 - Steps of the analytical procedures that constitute the method

\begin{tabular}{|c|c|}
\hline 1 & Definition of the study area \\
\hline 2 & $\begin{array}{l}\text { Gathering and selection of the population information available for the study area, as open and census } \\
\text { data }\end{array}$ \\
\hline 3 & Selection of the level of aggregation of the selected data \\
\hline $4 a$ & Characterization of the railway barrier through a field survey \\
\hline $4 \mathrm{~b}$ & $\begin{array}{l}\text { Characterization of urban street barriers using combined images of Google Street View and Google } \\
\text { Maps }\end{array}$ \\
\hline $5 b$ & $\begin{array}{l}\text { Delineation of the area of influence of urban streets considering overlapping areas, since for the } \\
\text { classification step (Step 9) each street was considered as an independent case }\end{array}$ \\
\hline 6 & Georeferencing of the study area using the open software Quantum GIS v.3.4.6 \\
\hline 7 & $\begin{array}{l}\text { Qualitative evaluation of the distinct types of crossings based on an appropriate set of criteria for each } \\
\text { facility }\end{array}$ \\
\hline $8 \mathrm{~b}$ & Creation of the PeCUS index from the sum of the criteria scores \\
\hline 9 & Classification of the quality of the transport barriers crossings based on the criteria assessed \\
\hline 10 & Delineation of the area of influence avoiding overlapping areas \\
\hline $11 \mathrm{~b}$ & $\begin{array}{l}\text { Random selection of three subsamples from the original sample of urban streets without overlapping } \\
\text { areas of influence }\end{array}$ \\
\hline 12 & $\begin{array}{l}\text { Estimate of the number of residents regarding the variables selected (using factors based on the } \\
\text { population distribution provided by the weighting areas multiplied by the number of inhabitants given } \\
\text { in the statistical grid and directly extracted from the statistical grid) }\end{array}$ \\
\hline 13 & Crossover of the estimated population within the areas of influence \\
\hline 14 & $\begin{array}{l}\text { Exploratory data analysis to characterize relevant aspects and outline conjectures about the residents } \\
\text { alongside the railway }\end{array}$ \\
\hline 15 & $\begin{array}{l}\text { Statistical analysis using the chi-square }\left(\chi^{2}\right) \text { tests of independence and the calculation of the } \\
\text { standardized Pearson residuals }\end{array}$ \\
\hline 16 & $\begin{array}{l}\text { Analysis of vertical equity through the calculation of deficits and excesses of residents in the } \\
\text { surrounding regions of the railroad crossings and segments without railroad crossings }\end{array}$ \\
\hline
\end{tabular}


Figure 3.5 - Flow diagram of the analytical procedures that constitute the method

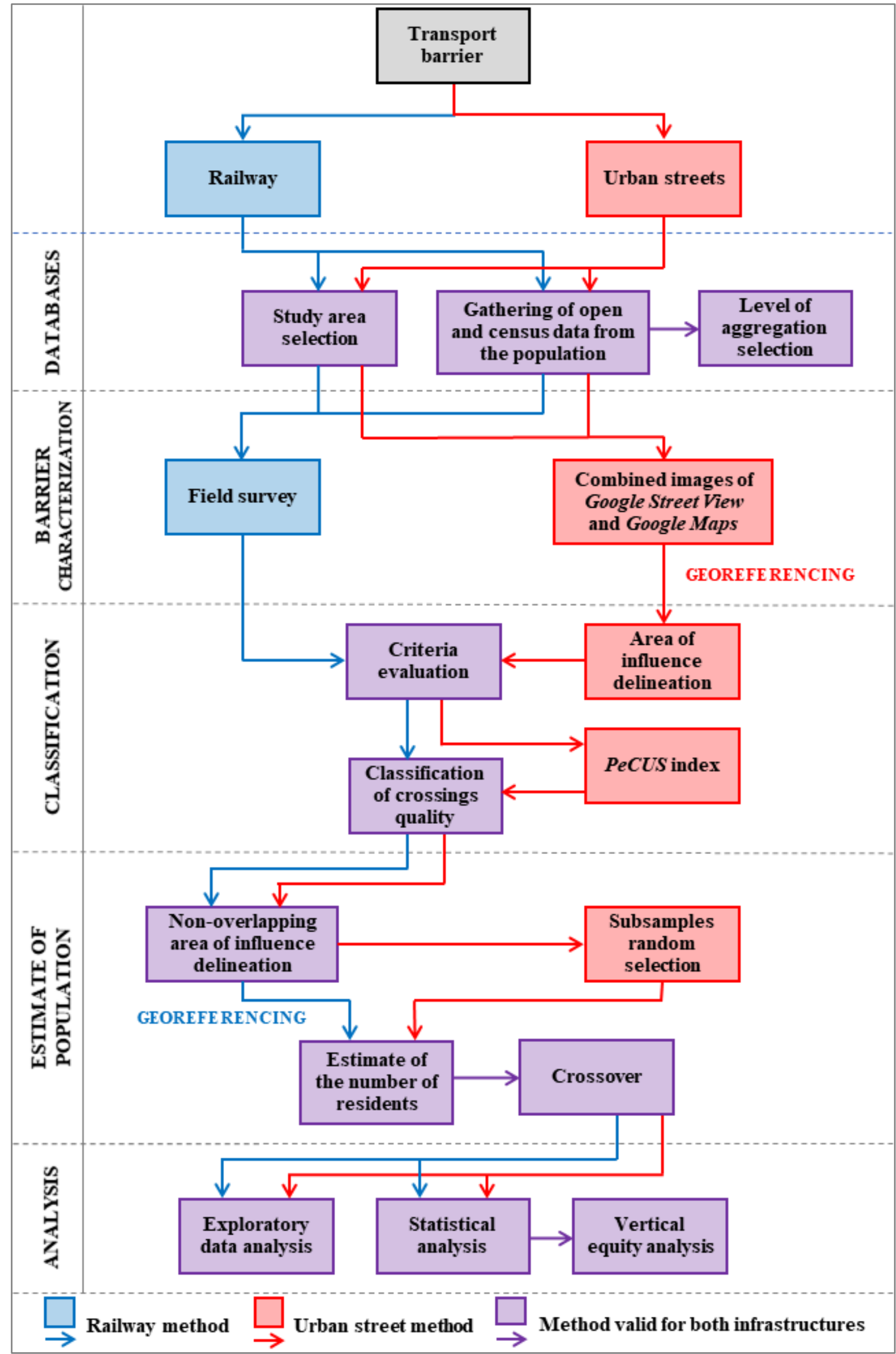

Source: The author 


\section{CASE STUDIES}

In this Chapter, we present the case studies used to illustrate the method created for the assessment of the community severance caused by a railway inserted in an urban perimeter, and by urban streets of a medium-sized Brazilian city.

Chapter 4 is divided into three Sections, in which the first Section has an overview of the study area. Sections 4.2 and 4.3 contain details of the railway and of the urban streets, respectively.

\subsection{Study area}

The case studies addressed in this research comprise a railway and urban streets located in a significant part of the urban region of the city of São Carlos. São Carlos is a medium-sized Brazilian city located in the state of São Paulo, as indicated in Figure 4.1(a). The population considered for this study included 213,010 inhabitants (IBGE, 2010) distributed over $83.5 \mathrm{~km}^{2}$, 13 weighting areas (Figure 4.1(b)) and 295 census tracts (Figure 4.1(c)). Weighting areas constitute geographical partitions formed by a mutually exclusive group of areas that follow technical restrictions concerning contiguity and size defined by the Brazilian Institute of Geography and Statistics (or IBGE, which in Portuguese stands for Instituto Brasileiro de Geografia e Estatística).

Figure 4.1 - Location of the city of São Carlos in the state of São Paulo (a). São Carlos subdivisions into weighting areas (b) and census tracts (c)
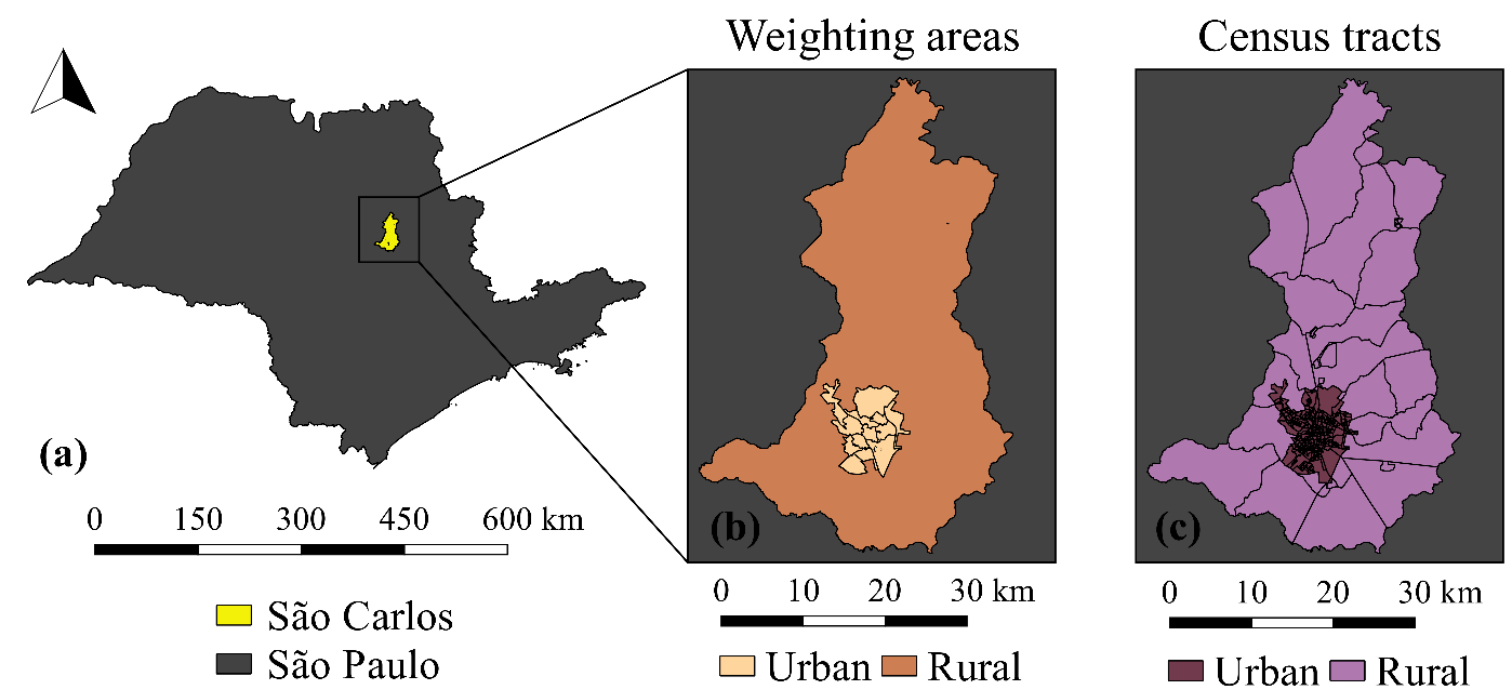

Source: The author 
Relevant demographic characteristics of the study area are: average monthly nominal income of R\$ 1,601.71, 36,000 inhabitants with some level of self-declared disability $(13,213$ of which with permanent mobility constraints), 108,795 female residents (with an average age of 38.0 years old) and 104,215 male residents (with an average age of 35.8 years old) (IBGE 2010).

\subsection{Case study 01: Railway within the urban perimeter}

For a better understanding of community severance and how it affects the distribution of the population in its surroundings, we first selected a transport barrier whose impact on pedestrian mobility is large, but its variability is small. That is the case of railways within the urban perimeter of cities, since the physical segregation of the infrastructure is practically unavoidable and the passage of pedestrians, cyclists and motorized vehicles, is only possible in the specific points where there are railroad crossings.

The urban perimeter of São Carlos city is cut by the Itirapina - Colômbia trunk railway line, operated by the concessionaire ALL (América Latina Logística Malha Paulista S.A.). The railway is at grade virtually throughout its entire way, has an average capacity of 11 railway compositions per day and a maximum traffic speed of $10 \mathrm{~km} / \mathrm{h}$ (maximum speed allowed in urban perimeter). Figure 4.2 shows the city of São Carlos, highlighting the weighting areas sectioned by the railway.

Figure 4.2 - Weighting areas sectioned by the railway in the city of São Carlos, SP, Brazil

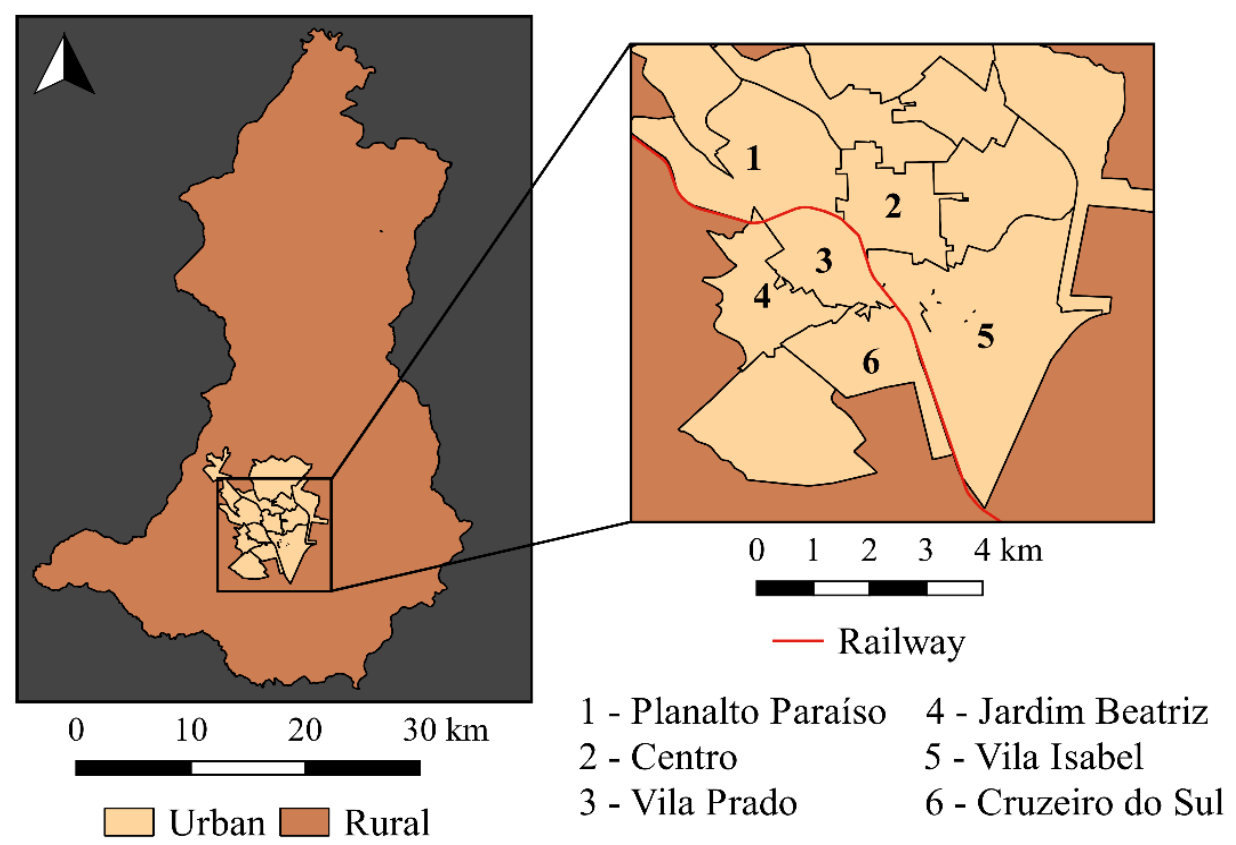

Source: The author 
The city growth was strongly influenced by the railway in the past. As a consequence, the population distribution along the railway within the urbanized region is quite homogeneous. The railway throughout the urban region includes the following types of crossings: level crossings (LC), pedestrian crossings (PC), overpasses (OP), underpasses (UP) and segments without railroad crossings (SWC), as shown in Figure 4.3.

Figure 4.3 - Location of railroad crossings and segments without railroad crossings in the city of São Carlos, SP, Brazil

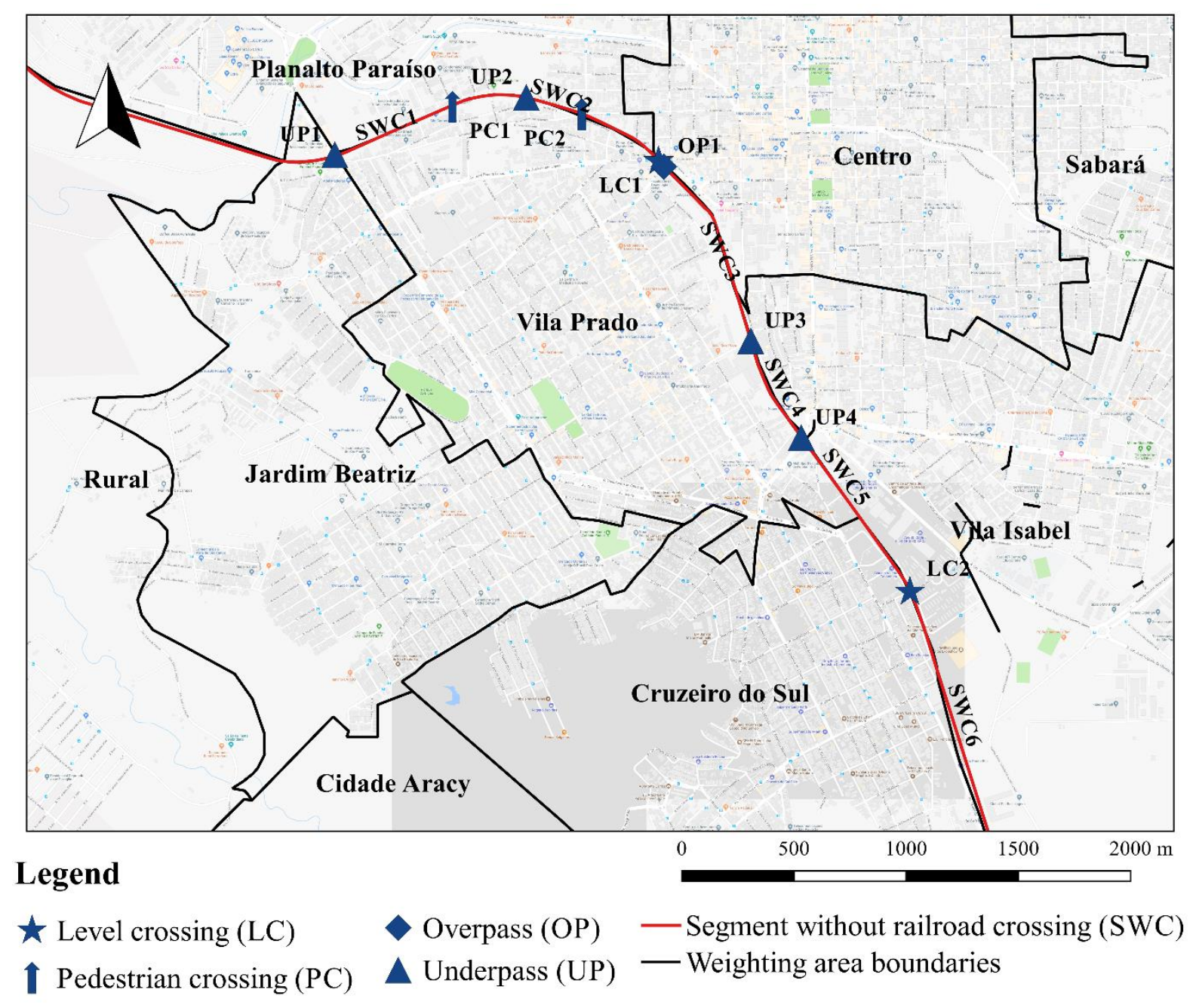

Source: The author

Some examples of types of railroad crossings along the railway and the segments without railroad crossings, within the urban perimeter, are illustrated in Figure 4.4. The segments without railroad crossings (SWC) have physical barriers preventing the passage of pedestrians, motorized and non-motorized vehicles along the whole way, however the material and the height of the barriers vary among segments. 
Figure 4.4 - Examples of types of crossings and segments without railroad crossings. From top left to bottom right: OP1, PC2, UP4 and SWC6
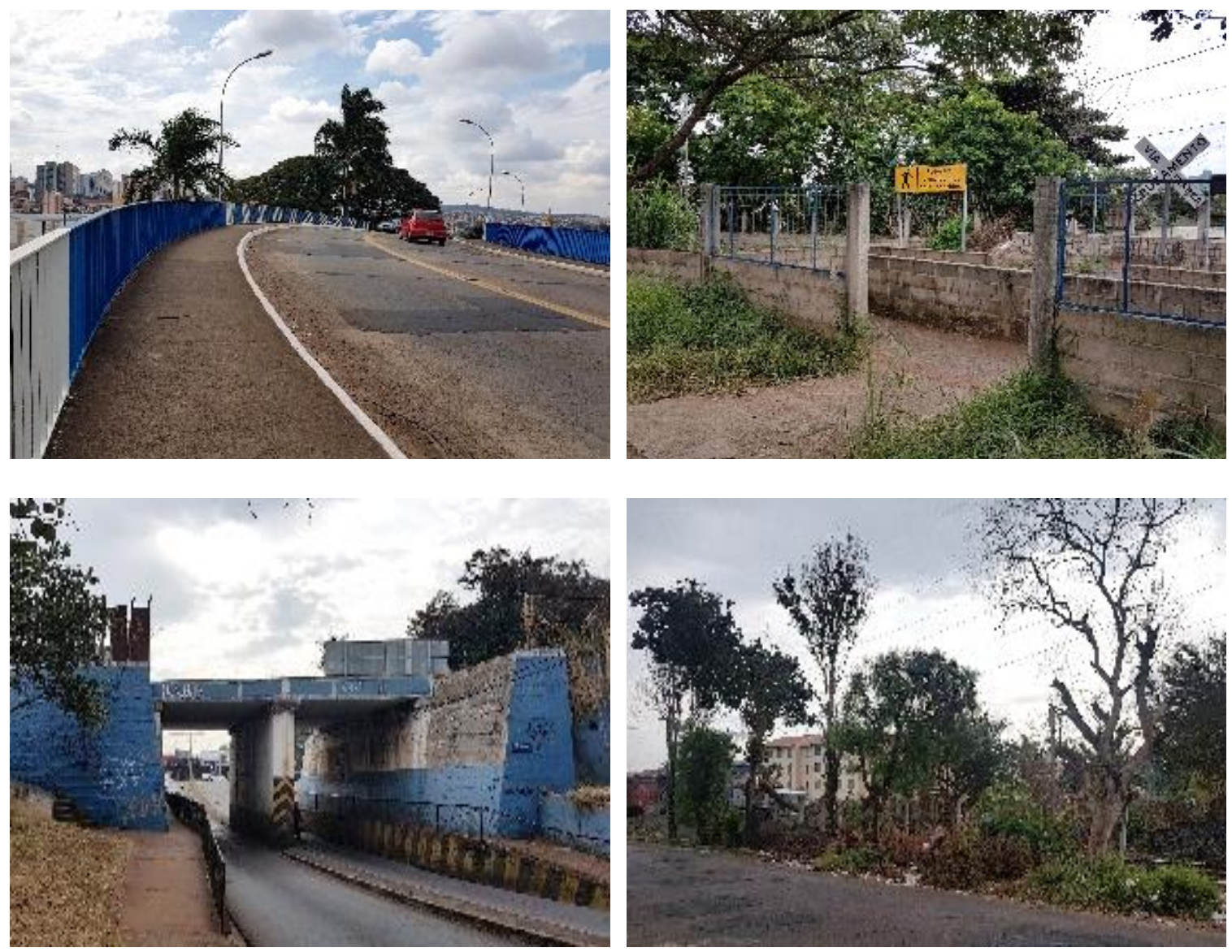

Note: OP - Overpass; PC - Pedestrian crossing; UP - Underpass e SWC - Segment without railroad crossing. Source: The author

\subsection{Case study 02: Urban streets}

The study case carried out for a railway located in the urban perimeter of a mediumsized city helped to understand the impact of community severance on the distribution of the nearby population. Thus, we developed a second case study in a transport barrier whose impacts can range from moderate to low, but their variability is considerably large throughout the entire barrier. That is the case of urban streets, given that pedestrians, depending on the traffic stream volume and road characteristics, can cross either on crossing facilities (formal passage) or between car gaps (informal passage). However, informal passages were not considered in this study.

The urban street network of São Carlos is typically laid out in a grid pattern comprising local streets, collector streets and arterial streets (primary and secondary). This functional classification of urban roads follows guidelines defined by the National Department of 
Transport Infrastructure (or DNIT, which in Portuguese stands for Departamento Nacional de Infraestrutura de Transportes) from 2010.

As São Carlos is a medium-sized city, its traffic stream ranges between low (below 600 vph (vehicles per hour)) and very high (above 1,000 vph), as presented in Figure 4.5.

Figure 4.5 - Overview of traffic volumes in the city of São Carlos, SP, Brazil

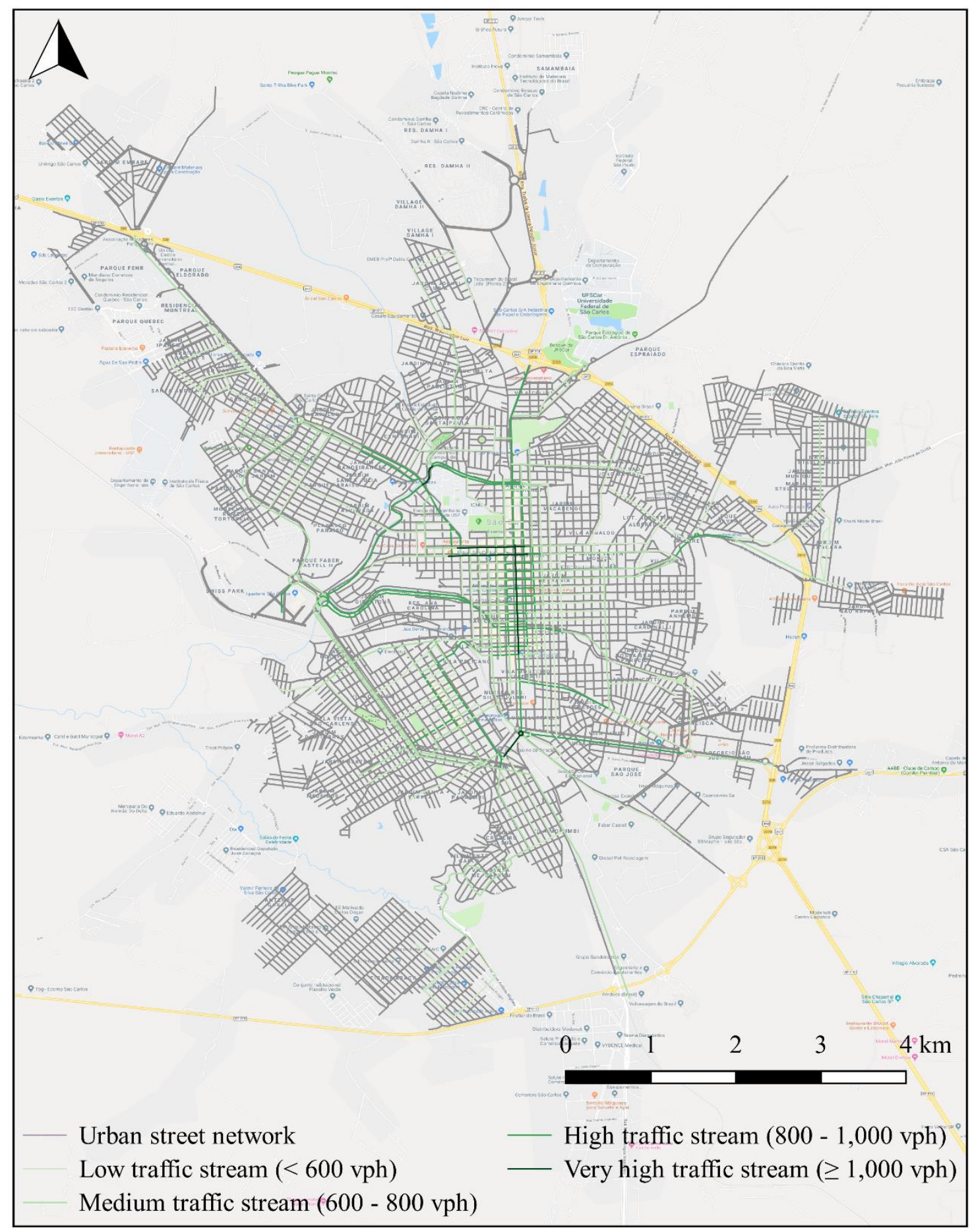

Source: Adapted from the map of roads hierarchy provided by the Municipal Housing and Urban Development Secretariat of São Carlos (in Portuguese: Secretaria Municipal de Habitação e Desenvolvimento Urbano), 2002 
In addition, pedestrian crossing facilities on urban streets are limited to raised or at level zebra crossings, with the occasionally presence of traffic lights or vertical/horizontal "STOP" signs. Some examples of pedestrian crossings on urban streets are illustrated in Figure 4.6.

Figure 4.6 - Examples of pedestrian crossings on urban streets
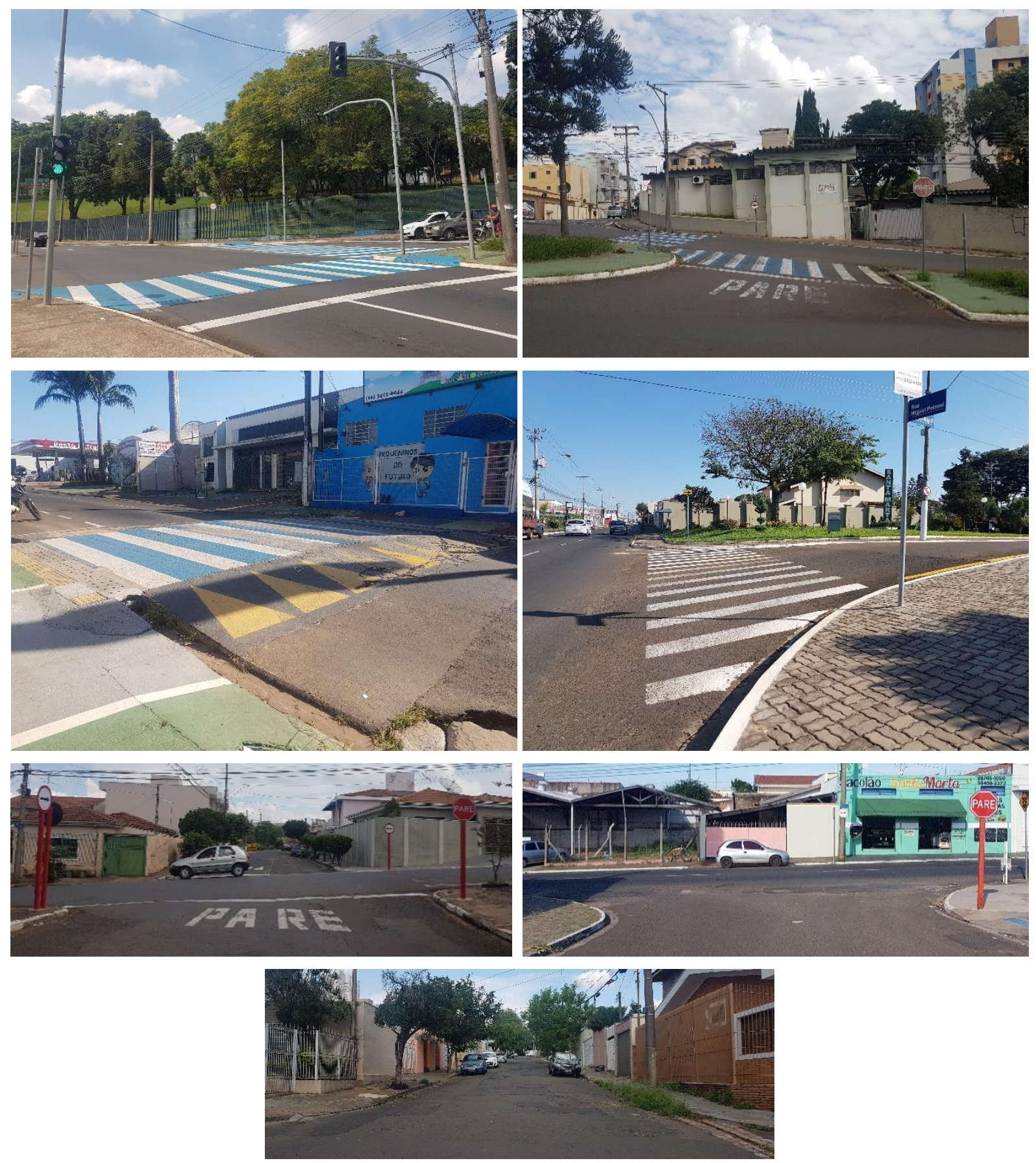

Note: From top left to bottom right: at level zebra crossing and traffic lights; at level zebra crossing, vertical and horizontal "STOP" signs; raised zebra crossing; at level zebra crossing; vertical and horizontal "STOP" signs; vertical "STOP" sign; absence of zebra crossing and signs.

Source: The author 


\section{RESULTS}

In this Chapter, we present and discuss the results from the implementation of the methods created for the assessment of the community severance caused by a railway inserted in an urban perimeter, and by urban streets. In addition, the vertical equity analysis regarding residents' distribution around the distinct classes of quality of pedestrian crossings for both infrastructures is carried out.

Chapter 5 is divided into four Sections. The first Section presents the data used, the second and third Sections describe the assessment of community severance for two case studies. Lastly, the final section presents a summary of the main results.

\subsection{Data collection}

The data collection for the assessment of community severance varies according to the transport barrier analyzed, as presented in Section 3.1. Moreover, the data collection is required for the characterization of the transport barriers and to estimate the population around them. The characterization of the transport barriers is carried out according to the evaluation of a set of criteria relevant to the particularities of each barrier (detailed in Table 3.2 and Table 3.3). On the other hand, population estimates depend on the availability and level of aggregation of the variables of interest.

Concerning the railway characterization, the data collection was carried out through field surveys. Databases were only needed for the estimate of the population around the railway crossings and segments without railway crossings, therefore population databases were gathered. However, data on safety and traffic volume were not available.

On the other hand, for the characterization of the urban streets, we collected data on the number of registered occurrences of crimes and deaths between 2010 and 2017, maps of location of lampposts (and its specifications) and land use, and disaggregated population data. In addition, for the estimate of the population around the urban streets, census data were gathered. However, data on traffic volume were not available.

The assessment of the vertical equity among residents within the specific areas of influence (railway and urban streets) was based on the estimate of the population nearby the transport barriers. For this purpose, we collected the following data from the 2010 Demographic Census: classes of monthly nominal income, groups of permanent mobility constraints, gender 
and age. However, the databases used for each transport barrier had different levels of aggregation.

Concerning the railway, the databases of the population by classes of monthly nominal income, the population with self-declared permanent mobility constraints, i.e. those who have difficulty walking or climbing stairs without the help of another person, and by age range were used by weighting areas. On the other hand, the gender data of the inhabitants were obtained from the database of the statistical grid.

In relation to the urban streets, monthly nominal income and permanent mobility constraints data were obtained by weighting areas, whereas data on gender and age were used at census tract level.

In addition, the spatial distribution of the urban population was based on the statistical grid from the 2010 Demographic Census and it was applied for both transport barriers. The statistical grid is available online in shapefile format.

In summary, besides the data used for the characterization of the transport barriers, five 2010 census databases combined with the spatial distribution of the population were used, as presented in Table 5.1. In addition to the demographic data, we used the geographic database from the Open Street Map (OSM) to locate the railway and create the urban street network.

Table 5.1 - Summary of the databases used and their corresponding level of aggregation per transport barrier

\begin{tabular}{|c|c|c|c|c|}
\hline Database & Railway & $\begin{array}{l}\text { Urban } \\
\text { streets } \\
\end{array}$ & $\begin{array}{c}\text { Aggregation } \\
\text { level }\end{array}$ & Source \\
\hline Income & $\mathrm{x}$ & $\mathrm{x}$ & $\begin{array}{l}\text { Weighting } \\
\text { areas }\end{array}$ & 2010 Demographic Census (IBGE) \\
\hline $\begin{array}{l}\text { Permanent mobility } \\
\text { constraints }\end{array}$ & $\mathrm{x}$ & $\mathrm{x}$ & $\begin{array}{c}\text { Weighting } \\
\text { areas }\end{array}$ & 2010 Demographic Census (IBGE) \\
\hline Gender & $\mathrm{x}$ & & Statistical grid & 2010 Demographic Census (IBGE) \\
\hline Age & $\mathrm{x}$ & & $\begin{array}{l}\text { Weighting } \\
\text { areas }\end{array}$ & 2010 Demographic Census (IBGE) \\
\hline Gender and age & & $\mathrm{x}$ & Census tracts & 2010 Demographic Census (IBGE) \\
\hline $\begin{array}{l}\text { Occurrences of crimes and } \\
\text { deaths }\end{array}$ & & $\mathrm{x}$ & Disaggregated & $\begin{array}{l}\text { Public Security Secretariat of São } \\
\text { Paulo }^{1}\end{array}$ \\
\hline $\begin{array}{l}\text { Location plan of lampposts } \\
\text { and its specifications }\end{array}$ & & $\mathrm{x}$ & Disaggregated & $\begin{array}{l}\text { Municipal Secretariat of Public } \\
\text { Services of São Carlos }\end{array}$ \\
\hline Land use map & & $\mathrm{x}$ & Disaggregated & $\begin{array}{l}\text { Municipal Secretariat of Housing and } \\
\text { Urban Development of São Carlos }\end{array}$ \\
\hline $\begin{array}{l}\text { Geometric Information } \\
\text { System }\end{array}$ & $\mathrm{x}$ & $\mathrm{x}$ & Disaggregated & Open Street Map (OSM) \\
\hline \multicolumn{5}{|c|}{$\begin{array}{l}1 \text { in Portuguese stands for Secretaria de Segurança Pública de São Paulo - SSP/SP } \\
2 \text { in Portuguese stands for Secretaria Municipal de Serviços Públicos } \\
3 \text { in Portuguese stands for Secretaria Municipal de Habitação e Desenvolvimento Urbano } \\
\text { Source: The author }\end{array}$} \\
\hline
\end{tabular}




\subsection{Case study 01: Assessment of the community severance caused by a Railway}

Based on the data collected and the delimited areas of influence, we classified the railroad crossings and segments without railroad crossings, carried out the exploratory data analysis and chi-square $\left(\chi^{2}\right)$ tests of independence, and evaluated the standardized Pearson residuals, as detailed in the subsequent Subsections.

\subsubsection{Classification of the types of railroad crossings and the segments without railroad crossings}

The characterization of each type of railroad crossing (LC, UP, OP and PC) and segment without railroad crossing (SWC) was performed according to the evaluation of a set of criteria (Subsection 3.2.1). The criteria were evaluated through a field survey, in which it is worth noting that only one of the level crossings "LC1" had a segregated pedestrian walkway, but it was not fully accessible and had no handrails. In the regions without railroad crossings, where the barrier was made of metal or chain-link fencing, there were many segments in bad and flawed conditions, which enabled an informal passage of passers-by. However, informal crossings were not considered in this study. Moreover, garbage and high vegetation was found alongside almost the whole length of the railway, except for the railroad crossings OP1, UP1, UP3 and UP4.

The classification of the railroad crossings and segments without railroad crossings was performed according to the percentage of conformance of the qualitative assessments based on a set of criteria. The railroad crossings and segments that met from $90.0 \%$ to $100.0 \%$ of the established criteria were associated with class A. Those attending from $80.0 \%$ to $90.0 \%$ were associated with class B, from $70.0 \%$ to $80.0 \%$, class C and from $33.0 \%$ to $70 \%$, class D. Thus, the different types of railroad crossings and segments were classified, as shown in Table 5.2.

Table 5.2 - Classification of types of railroad crossings and segments without railroad crossings (as shown in Figure 4.3) according to the percentage of conformance to the analyzed criteria

\begin{tabular}{|c|c|c|c|c|c|c|c|c|c|c|c|c|c|c|c|}
\hline \multirow{2}{*}{$\begin{array}{l}\text { Type of railroad } \\
\text { crossings }\end{array}$} & \multicolumn{2}{|c|}{ LC } & \multirow{2}{*}{$\begin{array}{c}\mathrm{OP} \\
1\end{array}$} & \multicolumn{4}{|c|}{ UP } & \multicolumn{2}{|c|}{$\mathrm{PC}$} & \multicolumn{6}{|c|}{ SWC } \\
\hline & 1 & 2 & & 1 & 2 & 3 & 4 & 1 & 2 & 1 & 2 & 3 & 4 & 5 & 6 \\
\hline$\%$ of conformance & 86 & 71 & 100 & 83 & 83 & 73 & 73 & 80 & 80 & 60 & 63 & 47 & 55 & 50 & 53 \\
\hline Class & $\mathrm{B}$ & $\mathrm{C}$ & $\mathrm{A}$ & $\mathrm{B}$ & $\mathrm{B}$ & $\mathrm{C}$ & $\mathrm{C}$ & $\mathrm{B}$ & $\mathrm{B}$ & $\mathrm{D}$ & $\mathrm{D}$ & $\mathrm{D}$ & $\mathrm{D}$ & $\mathrm{D}$ & $\mathrm{D}$ \\
\hline
\end{tabular}

Note: LC - Level crossing; OP - Overpass; UP - Underpass; PC - Pedestrian crossing and SWC - Segment without railroad crossings.

Source: The author 
Therefore, according to the proposed classification, based on the National Department of Transport Infrastructure (or DNIT, which in Portuguese stands for Departamento Nacional de Infraestrutura de Transportes) Railway Service Instructions (ISF - DNIT), only the overpass (OP1) was categorized as class A. The pedestrian crossings (PC1 and PC2), underpasses (UP1, UP2) and level crossing (LC1) located in the Centro, Jardim Beatriz, Planalto Paraíso and Vila Prado were categorized as class B. Underpasses (UP3, UP4) and level crossings (LC2) located in Vila Isabel and Cruzeiro do Sul were categorized as class C, while all segments without railroad crossings (SWC) were categorized as class D.

\subsubsection{Exploratory data analysis}

The exploratory data analysis of the variables of the different databases studied enabled us to describe aspects and make conjectures about the equity in the distribution of the number of residents along the railway and around the different types of railroad crossings.

For this reason, we produced graphs showing the total and partial proportions for each database, as shown in Figure 5.1 to Figure 5.4. Total proportions correspond to the analysis including the whole population on the database studied, whereas partial proportions indicate the analysis including only the population of a particular class of railway crossings. Therefore, from Figure 5.1 to Figure 5.4 (in percentage values), the distribution of the number of residents along the different types of railroad crossings and segments without railroad crossings regarding residents' demographic characteristics can be observed.

In relation to income distribution (Figure 5.1), most of the total number of residents $(86.6 \%)$ has a monthly nominal income of less than $\mathrm{R} \$ 2,550.00$, and more than half of the total (55.4\%) has a maximum income of $\mathrm{R} \$ 1,020.00$, nearly $36.3 \%$ below the average monthly nominal income of the city (excluding the rural area). The distribution of residents with income over R \$ 2,550.00 have greater differences among classes A, B and classes C, D. There is a substantially reduced number of residents $(1.4 \%)$ with a monthly nominal income greater than $\mathrm{R} \$ 10,200.00$. Classes $\mathrm{C}$ and $\mathrm{D}$ have residents predominantly with incomes lower than $\mathrm{R} \$ 1,020.00$ (59.8\% and 57.3\%, respectively) and in considerably higher proportions than in the other classes. Meanwhile, classes A and B have the higher portions of residents with income over $\mathrm{R} \$ 10,200.00$ (2.0\% and $2.5 \%$, respectively) and these proportions are almost twice the proportions in classes $\mathrm{C}$ and $\mathrm{D}$.

In the case of income distribution, it is expected that residents with lower incomes will be substantial along the best classified crossings, since these groups tend to do more active trips and are also part of vulnerable social groups. However, it is observed that the distribution of 
the population along the railway is predominantly comprised of residents with low-income. This could be explained by the anecdotal evidence showing that land prices along the railway are around 4 times less than land prices in the central area of the city. Thus, this pattern of residents' distribution could be an indicative that the railway tends to cause urban segregation and marginalization.

Figure 5.1 - Total (bar graph) and partial (sector graph) proportions of the number of residents with income as a function of the different classes of railroad crossings and segments without railroad crossings

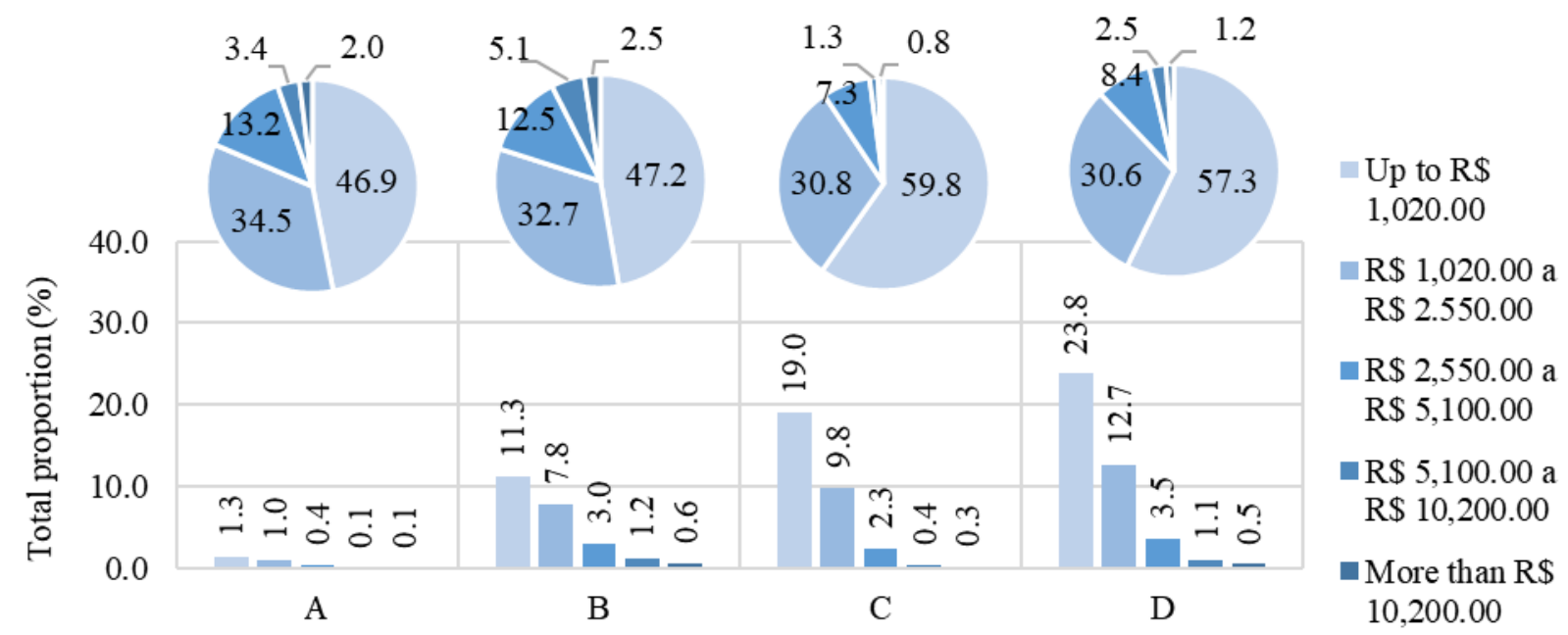

Source: The author

With respect to residents with permanent mobility constraints (Figure 5.2), the largest portion (31.1\%) of residents who live near class B railroad crossings are self-declared incapable of walking or climbing stairs without the help of another person, whereas the largest portions of residents with great difficulty or some difficulty or no disability $(38.9 \%, 39.5 \%$ and $41.8 \%$, respectively) live near the segments without railroad crossings (class D). Inversely, the smallest portions of residents in this database were observed living around class A railroad crossings, in which the highest portion occurs among residents with some difficulty (4.2\%). In addition, once the total proportions are analyzed, it can be observed that a small part of the residents distributed alongside the railway has permanent mobility constraints $(8.0 \%)$, in which $0.3 \%$ are incapable, $2.3 \%$ have great difficulty and $5.3 \%$ some difficulty.

Even though a minority of the population lives close to the railroad that has some degree of mobility constraints, it is expected that the distribution of these vulnerable groups will be preferred along the best classified crossings. However, it is observed that the distribution of the population along the railway is similar for all groups, except for the self-declared incapable residents whose distribution is significant around class B railroad crossings. 
Figure 5.2 - Total (bar graph) and partial (sector graph) proportions of the number of residents per class of types of railroad crossings ( $\mathrm{A}$ is the best and $\mathrm{D}$ the worst) and segments without railroad crossings as a function of permanent mobility constraints

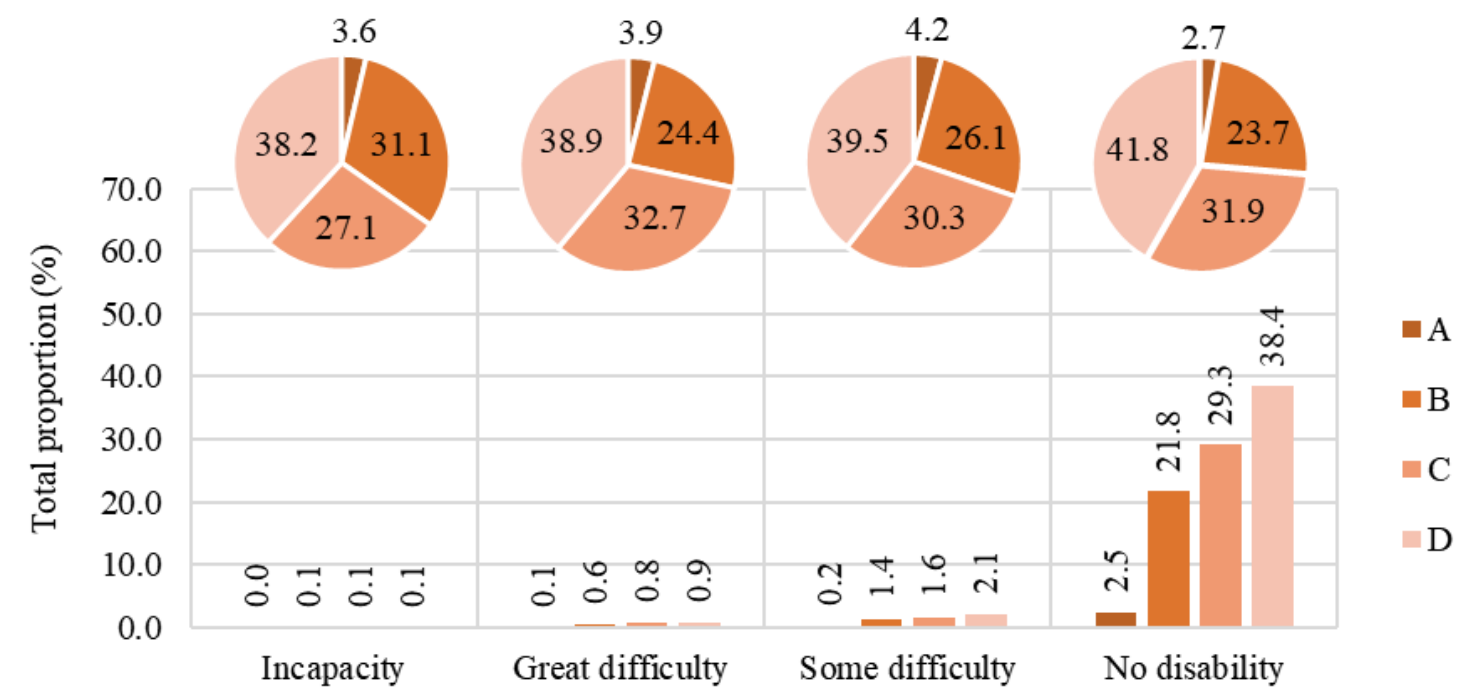

Source: The author

Figure 5.3 - Total (bar graph) and partial (sector graph) proportions of the number of residents by gender as a function of the different classes of railroad crossings and segments without railroad crossings

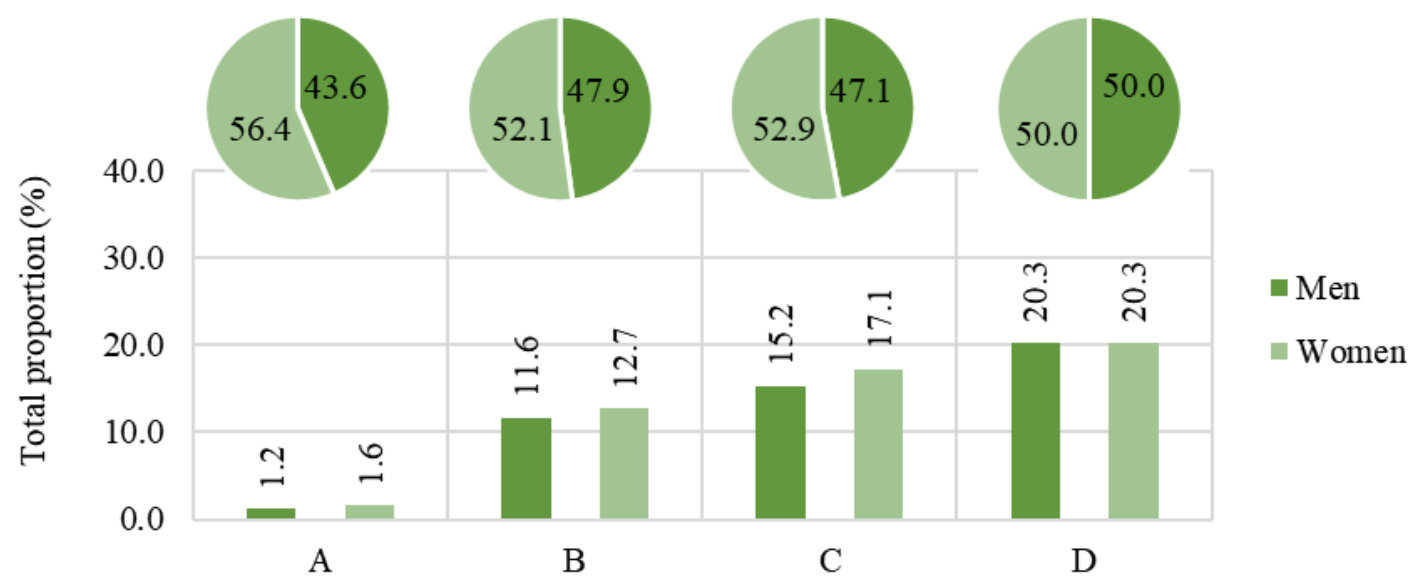

Source: The author

The number of women is proportionally higher surrounding class A railroad crossings (56.4\%), while in the other classes of railroad crossings there is a slightly higher distribution for female residents (52.1\% and 52.9\%), as presented in Figure 5.3. It can also be observed that gender distribution along the segments without railroad crossings are balanced (50\%, class D). In addition, almost half of the population $(20.3 \%+20.3 \%)$ lives in regions without any railroad crossings (class D), indicating that there may be a need for implementing more railroad crossings. 
The distribution of residents who live close to class A and B railroad crossings is slightly higher for the residents aged over 60 years old (27.2\% and $20.7 \%$, respectively), as illustrated in Figure 5.4. While in classes C and D, the age ranges from 20 to 29 years old are slightly greater than the other categories ( $20.1 \%$ and $19.8 \%$, respectively). It can also be observed that the age range corresponding to up to 19 years old presents the lowest values for class A and B railroad crossings ( $11.7 \%$ and $13.7 \%$, respectively).

In relation to age, it is expected that children and the elderly will be preferably distributed along the best classified crossings, since these vulnerable groups cannot walk long distances and for long periods. However, our data is aggregated for children and young adults (age range up to 19 years old), thus the results for children are unclear. For the elderly, it is observed that their distribution is considerably higher in the best classified railroad crossings.

Figure 5.4 - Total (bar graph) and partial (sector graph) proportions of the number of residents by age range as a function of the different classes of railroad crossings and segments without railroad crossings

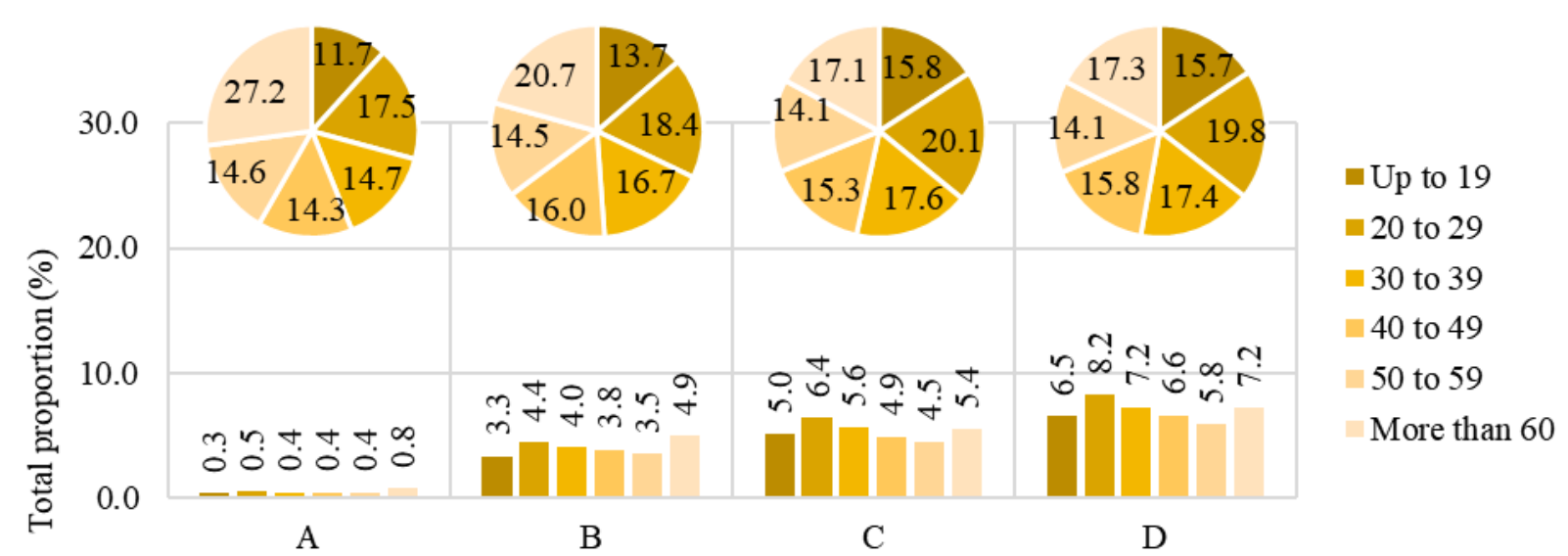

Source: The author

\subsubsection{Chi-square $\left(\chi^{2}\right)$ test of independence and standardized Pearson residuals}

The exploratory data analysis (Subsection 5.2.2) showed relevant aspects between the variables but it did not validate the hypothesis of association among them, therefore the chisquare $\left(\chi^{2}\right)$ test of independence was used as a hypothesis test in contingency tables built from values of the variables of the different databases studied. Thus, the chi-square $\left(\chi^{2}\right)$ test is used to accept or reject the hypothesis of independence between the variables $\left(\mathrm{H}_{0}\right)$.

The calculations of the squared Pearson residual, the standardized Pearson residuals and the chi-square $\left(\chi^{2}\right)$ test of independence for the database concerning the variables of classification of railroad crossings and segments without railroad crossings and (i) number of residents by range of monthly nominal income are indicated in Table 5.3. The chi-square $\left(\chi^{2}\right)$ 
value obtained was equal to 403.8902 and it corresponds to a p-value of $5.6777 \times 10^{-79}$ (which is smaller than 0.0250). Hence, hypothesis $\mathrm{H}_{0}$ is rejected at a level of significance of less than 0.0250 , then a possible association between the variables of classification and (i) number of residents by range of monthly nominal income cannot be ruled out.

Table 5.3 - Squared Pearson residuals ( $\left.\mathrm{PR}^{2}\right)$, standardized Pearson residuals (SPR) and chi-square $\left(\chi^{2}\right)$ test of independence between the variables of classification (of the types of railroad crossings and segments without railroad crossings) and number of residents by range of monthly nominal income

\begin{tabular}{|c|c|c|c|c|c|c|c|}
\hline \multirow[b]{2}{*}{ Class } & \multirow[b]{2}{*}{ Calculations } & \multicolumn{5}{|c|}{ Range of monthly nominal income (number of residents) } & \multirow[b]{2}{*}{ Total } \\
\hline & & $\begin{array}{c}\text { Up to } \\
\mathrm{R} \$ 1,020.00\end{array}$ & $\begin{array}{c}\mathrm{R} \$ 1,020.00 \text { to } \\
\mathrm{R} \$ 2,550.00\end{array}$ & $\begin{array}{c}\mathrm{R} \$ 2,550.00 \text { to } \\
\mathrm{R} \$ 5,100.00\end{array}$ & $\begin{array}{c}\mathrm{R} \$ 5,100.00 \text { to } \\
\mathrm{R} \$ 10,200.00\end{array}$ & $\begin{array}{c}\text { More than } \\
\mathrm{R} \$ 10,200.00\end{array}$ & \\
\hline \multirow{4}{*}{ A } & Observed & 266 & 196 & 75 & 19 & 11 & 567 \\
\hline & Expected & 314 & 177 & 52 & 16 & 8 & 567 \\
\hline & $\mathrm{PR}^{2}$ & 7.4426 & 1.9674 & 10.0331 & 0.7709 & 1.4011 & \\
\hline & SPR & -4.14 & +1.72 & +3.37 & +0.90 & +1.21 & \\
\hline \multirow{4}{*}{ B } & Observed & 2,270 & 1,573 & 603 & 243 & 119 & 4,808 \\
\hline & Expected & 2,664 & 1,503 & 443 & 133 & 67 & 4,808 \\
\hline & $\mathrm{PR}^{2}$ & 58.0327 & 3.2852 & 58.3111 & 92.0336 & 40.0690 & \\
\hline & SPR & -13.07 & +2.50 & +9.18 & +11.15 & +7.30 & \\
\hline \multirow{4}{*}{ C } & Observed & 3,836 & 1,972 & 470 & 81 & 53 & 6,413 \\
\hline & Expected & 3,552 & 2,004 & 590 & 177 & 89 & 6,413 \\
\hline & $\mathrm{PR}^{2}$ & 22.7015 & 0.5101 & 24.4532 & 52.1301 & 14.3965 & \\
\hline & SPR & +8.64 & -1.04 & -6.28 & -8.87 & -4.63 & \\
\hline \multirow{4}{*}{ D } & Observed & 4,804 & 2,564 & 708 & 213 & 97 & 8,387 \\
\hline & Expected & 4,646 & 2,621 & 772 & 231 & 117 & 8,387 \\
\hline & $\mathrm{PR}^{2}$ & 5.3414 & 1.2377 & 5.2050 & 1.3895 & 3.1787 & \\
\hline & SPR & +4.53 & -1.76 & -3.13 & -1.56 & -2.35 & \\
\hline \multirow{2}{*}{ Total } & Observed & 11,176 & 6,305 & 1,857 & 557 & 281 & 20,175 \\
\hline & Expected & 11,176 & 6,305 & 1,857 & 557 & 281 & 20,175 \\
\hline \multicolumn{2}{|c|}{$\chi^{2}=\sum \mathrm{PR}^{2}$} & \multicolumn{6}{|c|}{403.8902} \\
\hline \multicolumn{2}{|c|}{$\mathrm{p}$-value } & \multicolumn{6}{|c|}{$5.6777 \times 10^{-79}(12$ degrees of freedom $)$} \\
\hline
\end{tabular}

Note: PR ${ }^{2}$ - Squared Pearson residual; SPR - Standardized Pearson residual

Source: The author

In addition, based on the standardized Pearson residuals shown in Table 5.3, it was observed that there is a smaller than expected count of population that has an income less than $\mathrm{R} \$ 1,020.00$ who lives near classes $\mathrm{A}$ and $\mathrm{B}$, that is, there is a deficit of residents as can be seen through the values -4.14 and -13.07 , respectively, (in absolute values is higher than 2) and the negative signs. For the same social group presented previously, there is a larger than expected count of inhabitants that lives near classes $\mathrm{C}$ and $\mathrm{D}$, that is, an excess of residents as can be perceived by the values +8.64 and +4.53 , respectively, (in absolute values is higher than 2 ) and the positive signs. There are excesses of residents with an income greater than $\mathrm{R} \$ 5,100.00$ that 
live near class B railroad crossings, and deficits of residents of the same social groups living along classes C and D. Additionally, there is an excess of residents' distribution of the social group with an income between $\mathrm{R} \$ 1,020.00$ and $\mathrm{R} \$ 2,550.00$ that live near class $\mathrm{B}$ railroad crossings, an excess of residents with an income between $\mathrm{R} \$ 2,550.00$ and $\mathrm{R} \$ 5,100.00$ living around classes $\mathrm{A}$ and $\mathrm{B}$ and a deficit of residents with the later income range that live around classes C and D.

Analogously, we conducted the determination of the squared Pearson residuals, the standardized Pearson residuals and the chi-square $\left(\chi^{2}\right)$ test of independence for the databases regarding the variables of classification and for the other variables of: (ii) number of residents with self-declared permanent mobility constraints; (iii) number of residents by gender and (iv) number of residents by age range.

The standardized Pearson residuals and the chi-square $\left(\chi^{2}\right)$ test of independence for the database concerning the variables of classification of railroad crossings and segments without railroad crossings and the number of residents with self-declared permanent mobility constraints are indicated in Table 5.4. The chi-square $\left(\chi^{2}\right)$ test of independence presented only $6.3 \%$ of the total expected counts below 5.0. As the test permits up to $20 \%$ of the expected counts less than 5.0, the application of the test in the database was possible. Since the chi-square $\left(\chi^{2}\right)$ value (18.0581) matched a p-value of 0.0345 (which is smaller than 0.0500 ), we reject the hypothesis $\mathrm{H}_{0}$ with a significance level of 0.05 . Therefore, we cannot rule out the possibility of an association between the variables of classification and (ii) number of residents with selfdeclared permanent mobility constraints.

In addition, based on the standardized Pearson residuals shown in Table 5.4, it was observed that there is a larger than expected (excess) count of inhabitants that is self-declared with some difficulty living near the class A railroad crossings. For residents with no disability that live in the class A surroundings, there is a smaller than expected count (deficit) of population. In addition, the standardized Pearson residuals found for all permanent mobility constraints categories in classes B, C and D, and residents self-declared incapable or with great difficulty in class A are less than 2 (in absolute values). Therefore, the squared Pearson residuals $\left(\mathrm{PR}^{2}\right)$ values of those categories contribute little to the chi-square $\left(\chi^{2}\right)$ calculation and are consequently poorly associated with the permanent mobility constraints of the residents who live near the railroad crossings of those classes. 
Table 5.4 - Squared Pearson residuals (PR $\left.{ }^{2}\right)$, standardized Pearson residuals (SPR) and chi-square $\left(\chi^{2}\right)$ test of independence between the variables of classification (types of railroad crossings and segments without railroad crossings) and number of residents with self-declared permanent mobility constraints

\begin{tabular}{|c|c|c|c|c|c|c|}
\hline \multirow{2}{*}{ Class } & \multirow{2}{*}{ Calculations } & \multicolumn{3}{|c|}{ Permanent mobility constraints (number of residents) } & \multirow{2}{*}{$\begin{array}{c}\text { No } \\
\text { disability }\end{array}$} & \multirow{2}{*}{ Total } \\
\hline & & Incapacity & Great difficulty & Some difficulty & & \\
\hline \multirow{4}{*}{ A } & Observed & 2 & 19 & 44 & 501 & 567 \\
\hline & Expected & 2 & 13 & 30 & 522 & 567 \\
\hline & $\mathrm{PR}^{2}$ & 0.1691 & 2.1932 & 7.0385 & 0.8044 & \\
\hline & SPR & +0.42 & +1.52 & +2.77 & -3.22 & \\
\hline \multirow{4}{*}{ B } & Observed & 21 & 116 & 278 & 4,396 & 4,812 \\
\hline & Expected & 16 & 113 & 254 & 4,428 & 4,812 \\
\hline & $\mathrm{PR}^{2}$ & 1.5245 & 0.0716 & 2.2928 & 0.2308 & \\
\hline & SPR & +1.42 & +0.31 & +1.78 & -1.95 & \\
\hline \multirow{4}{*}{$\mathrm{C}$} & Observed & 19 & 155 & 322 & 5,920 & 6,416 \\
\hline & Expected & 22 & 151 & 339 & 5,905 & 6,416 \\
\hline & $\mathrm{PR}^{2}$ & 0.4819 & 0.1252 & 0.7753 & 0.0386 & \\
\hline & SPR & -0.84 & +0.43 & -1.10 & +0.84 & \\
\hline \multirow{4}{*}{$\mathrm{D}$} & Observed & 26 & 184 & 420 & 7,757 & 8,388 \\
\hline & Expected & 29 & 197 & 443 & 7,720 & 8,388 \\
\hline & $\mathrm{PR}^{2}$ & 0.1892 & 0.8049 & 1.1374 & 0.1807 & \\
\hline & SPR & -0.57 & -1.19 & -1.43 & +1.97 & \\
\hline \multirow{2}{*}{ Total } & Observed & 69 & 474 & 1,065 & 18,574 & 20,182 \\
\hline & Expected & 69 & 474 & 1,065 & 18,574 & 20,182 \\
\hline \multicolumn{2}{|c|}{$\chi^{2}=\sum \mathrm{PR}^{2}$} & \multicolumn{5}{|c|}{18.0581} \\
\hline \multicolumn{2}{|c|}{ p-value } & \multicolumn{5}{|c|}{0.0345 ( 9 degrees of freedom) } \\
\hline
\end{tabular}

Note: PR $^{2}$ - Squared Pearson residual; SPR - Standardized Pearson residual

Source: The author

For the database related to the variables of classification and (iii) number of residents by gender, considering the result equivalent to 22.7977 and a p-value equal to $4.4500 \times 10^{-5}$ (which is smaller than 0.0250 ), hypothesis $\mathrm{H}_{0}$ is rejected with a significance level of 0.0250 (Table 5.5). Thus, also in this case the test shows evidence of association between the variables.

Regarding the standardized Pearson residuals shown in Table 5.5, it can be observed that there is a deficit of men who live around classes $\mathrm{A}$ and $\mathrm{C}$ railroad crossings, while there is an excess of men living near classes B and D. Inversely, for women there is an excess living near classes $\mathrm{A}$ and $\mathrm{C}$ railroad crossings, whereas there is a deficit living around classes $\mathrm{B}$ and D. 
Table 5.5 - Squared Pearson residuals ( $\left.\mathrm{PR}^{2}\right)$, standardized Pearson residuals (SPR) and chi-square $\left(\chi^{2}\right)$ test of independence between the variables of classification (of the types of railroad crossings and segments without railroad crossings) and number of residents by gender

\begin{tabular}{|c|c|c|c|c|}
\hline \multirow{2}{*}{ Class } & \multirow{2}{*}{ Calculations } & \multicolumn{2}{|c|}{ Population (number of residents) } & \multirow{2}{*}{ Total } \\
\hline & & Men & Women & \\
\hline \multirow{4}{*}{ A } & Observed & 247 & 320 & 567 \\
\hline & Expected & 278 & 289 & 567 \\
\hline & $\mathrm{PR}^{2}$ & -1.8469 & 1.8111 & \\
\hline & SPR & -2.62 & +2.62 & \\
\hline \multirow{4}{*}{ B } & Observed & 4,016 & 4,016 & 8,031 \\
\hline & Expected & 3,937 & 4,094 & 8,031 \\
\hline & $\mathrm{PR}^{2}$ & 1.2521 & -1.2278 & \\
\hline & SPR & +2.17 & -2.17 & \\
\hline \multirow{4}{*}{$\mathrm{C}$} & Observed & 3,019 & 3,397 & 6,416 \\
\hline & Expected & 3,145 & 3,271 & 6,416 \\
\hline & $\mathrm{PR}^{2}$ & -2.2528 & 2.2092 & \\
\hline & SPR & -3.71 & +3.71 & \\
\hline \multirow{4}{*}{$\mathrm{D}$} & Observed & 4,016 & 4,016 & 8,031 \\
\hline & Expected & 3,937 & 4,094 & 8,031 \\
\hline & $\mathrm{PR}^{2}$ & 1.2521 & -1.2278 & \\
\hline & SPR & +2.17 & -2.17 & \\
\hline \multirow{2}{*}{ Total } & Observed & 11,297 & 11,748 & 23,045 \\
\hline & Expected & 11,297 & 11,748 & 23,045 \\
\hline \multicolumn{2}{|c|}{$\chi^{2}=\sum \mathrm{PR}^{2}$} & \multicolumn{3}{|c|}{22.7977} \\
\hline \multicolumn{2}{|c|}{ p-value } & \multicolumn{3}{|c|}{$4.4500 \times 10^{-5}(3$ degrees of freedom $)$} \\
\hline
\end{tabular}

Note: PR ${ }^{2}$ - Squared Pearson residual; SPR - Standardized Pearson residual Source: The author

Furthermore, the chi-square $\left(\chi^{2}\right)$ test of independence obtained for the database regarding the variables of classification and number of residents by age range was equivalent to 74.7030 and it corresponds to a p-value of $6.4062 \times 10-10$ (which is smaller than 0.0250), as indicated in Table 5.6. Hence, the hypothesis $\mathrm{H}_{0}$ is rejected at a level of significance of less than 0.0250 , then we cannot rule out a possible association between the variables of classification and (iv) number of residents by age.

Regarding the standardized Pearson residuals shown in Table 5.6, it was noted that there is a portion of the population aged up to 19 who live near classes A and B, that is smaller than the expected (deficit). For the population aged between 20 and 29 years, there is a deficit of people living near the regions of class B railroad crossings. For the population over 60 years of age, there is an excess of residents near classes A and B railroad crossings and a deficit of residents near classes $\mathrm{C}$ and $\mathrm{D}$. 
Table 5.6 - Squared Pearson residuals ( $\left.\mathrm{PR}^{2}\right)$, standardized Pearson residuals (SPR) and chi-square $\left(\chi^{2}\right)$ test of independence between the variables of classification (of the types of railroad crossings and segments without railroad crossings) and number of residents by age range

\begin{tabular}{|c|c|c|c|c|c|c|c|c|}
\hline \multirow{2}{*}{ Class } & \multirow{2}{*}{ Calculations } & \multicolumn{6}{|c|}{ Age ranges (number of residents) } & \multirow{2}{*}{ Total } \\
\hline & & Up to 19 & 20 to 29 & 30 to 39 & 40 to 49 & 50 to 59 & More than 60 & \\
\hline \multirow{4}{*}{ A } & Observed & 67 & 99 & 83 & 81 & 83 & 154 & 567 \\
\hline & Expected & 86 & 110 & 98 & 89 & 80 & 104 & 567 \\
\hline & $\mathrm{PR}^{2}$ & 4.3932 & 1.1399 & 2.1188 & 0.6137 & 0.0615 & 24.2560 & \\
\hline & SPR & -2.31 & -1.21 & -1.62 & -0.87 & +0.27 & +5.53 & \\
\hline \multirow{4}{*}{ B } & Observed & 661 & 886 & 806 & 769 & 697 & 997 & 4,815 \\
\hline & Expected & 730 & 938 & 829 & 754 & 683 & 882 & 4,815 \\
\hline & $\mathrm{PR}^{2}$ & 6.5473 & 2.8875 & 0.6448 & 0.3005 & 0.2958 & 15.0029 & \\
\hline & SPR & -3.18 & -2.17 & -1.01 & +0.68 & +0.67 & +4.91 & \\
\hline \multirow{4}{*}{$\mathrm{C}$} & Observed & 1,016 & 1,288 & 1,128 & 984 & 903 & 1,099 & 6,416 \\
\hline & Expected & 973 & 1,250 & 1,105 & 1,004 & 910 & 1,175 & 6,416 \\
\hline & $\mathrm{PR}^{2}$ & 1.9015 & 1.1546 & 0.4677 & 0.3931 & 0.0593 & 4.9812 & \\
\hline & SPR & +1.81 & +1.45 & +0.91 & -0.83 & -0.32 & -2.99 & \\
\hline \multirow{4}{*}{$\mathrm{D}$} & Observed & 1,316 & 1,658 & 1,458 & 1,324 & 1,180 & 1,447 & 8,384 \\
\hline & Expected & 1,271 & 1,633 & 1,444 & 1,312 & 1,189 & 1,536 & 8,384 \\
\hline & $\mathrm{PR}^{2}$ & 1.6331 & 0.3912 & 0.1512 & 0.1135 & 0.0695 & 5.1253 & \\
\hline & SPR & +1.81 & +0.91 & +0.56 & +0.48 & -0.37 & -3.28 & \\
\hline \multirow{2}{*}{ Total } & Observed & 3,059 & 3,931 & 3,475 & 3,159 & 2,862 & 3,697 & 20,183 \\
\hline & Expected & 3,059 & 3,931 & 3,475 & 3,159 & 2,862 & 3,697 & 20,183 \\
\hline \multicolumn{2}{|c|}{$\chi^{2}=\sum \mathrm{PR}^{2}$} & \multicolumn{7}{|c|}{74.7030} \\
\hline \multicolumn{2}{|c|}{ p-value } & \multicolumn{7}{|c|}{$6.4062 \times 10^{-10}(15$ degrees of freedom $)$} \\
\hline
\end{tabular}

Note: PR $^{2}$ - Squared Pearson residual; SPR - Standardized Pearson residual

Source: The author

Table 5.7 presents a summary of excesses and deficits of residents with different demographic characteristics that live surrounding the distinct classes of railroad crossings and segments without railroad crossings. It also brings information about the positive (+) or negative (-) effect of the excess/deficit to the vertical equity in the residents' distribution along the railway. This happens because excesses/deficits of residents living near a determined class of railroad crossing or segment without crossings could denote a positive or negative effect to vertical equity depending on which social group it is related to.

In relation to the variable monthly nominal income, the deficit of residents with income less than $\mathrm{R} \$ 1,020.00$ living in classes A and B surroundings, and the excess of the same social group that lives near classes $\mathrm{C}$ and $\mathrm{D}$ denote a negative effect to the vertical equity. As in the excess of residents with an income greater than $\mathrm{R} \$ 5,100.00$ that live near class $\mathrm{B}$ railroad crossings, and the deficit of residents of the same social groups living along classes C and D indicate a negative effect to the vertical equity. On the contrary, a positive effect to the vertical equity corresponds to the excess of residents' distribution of the social group with an income 
between $\mathrm{R} \$ 1,020.00$ and $\mathrm{R} \$ 2,550.00$ that live near class $\mathrm{B}$ railroad crossings, an excess of residents' distribution of the social group with an income between $R \$ 2,550.00$ and $R \$ 5,100.00$ living around classes $\mathrm{A}$ and $\mathrm{B}$ and a deficit of residents with the later income range that live around classes $\mathrm{C}$ and D. This is because regarding the vertical equity, it is expected that residents with lower incomes (less than $\mathrm{R} \$ 2,550.00$ ) will be preferred along the best classified crossings, since these groups tend to do more active trips and are also considered vulnerable social groups. We also assumed that the excess of residents with an intermediary income (from $\mathrm{R} \$ 2,550.00$ to $\mathrm{R} \$ 5,100.00)$ is positive.

Table 5.7 - Summary of excesses and deficits for the variables of classification (of the types of railroad crossings and segments without railroad crossings) regarding income, permanent mobility constraints, gender and age

\begin{tabular}{|c|c|c|c|c|c|}
\hline & & & & & \\
\hline & & & & & \\
\hline & & $\mathrm{A}$ & B & $\mathrm{C}$ & $\mathrm{D}$ \\
\hline \multirow{5}{*}{$\begin{array}{l}\text { Range of } \\
\text { monthly } \\
\text { nominal } \\
\text { income }\end{array}$} & $\begin{array}{c}\text { Up to } \\
\mathrm{R} \$ 1,020.00\end{array}$ & Deficit (-) & Deficit (-) & Excess (-) & Excess (-) \\
\hline & $\begin{array}{c}\mathrm{R} \$ 1,020.00 \text { to } \\
\mathrm{R} \$ 2,550.00\end{array}$ & $\mathrm{NR}^{1}$ & Excess (+) & $\mathrm{NR}^{1}$ & $\mathrm{NR}^{1}$ \\
\hline & $\begin{array}{c}\mathrm{R} \$ 2,550.00 \text { to } \\
\mathrm{R} \$ 5,100.00\end{array}$ & Excess (+) & Excess (+) & Deficit (+) & Deficit $(+)$ \\
\hline & $\begin{array}{c}\mathrm{R} \$ 5,100.00 \text { to } \\
\mathrm{R} \$ 10,200.00\end{array}$ & $\mathrm{NR}^{1}$ & Excess (-) & Deficit (-) & $\mathrm{NR}^{1}$ \\
\hline & $\begin{array}{c}\text { More than } \\
\mathrm{R} \$ 10,200.00\end{array}$ & $\mathrm{NR}^{1}$ & Excess (-) & Deficit (-) & Deficit (-) \\
\hline \multirow{4}{*}{$\begin{array}{l}\text { Permanent } \\
\text { mobility } \\
\text { constraints }\end{array}$} & Incapacity & $\mathrm{NR}^{1}$ & $\mathrm{NR}^{1}$ & $\mathrm{NR}^{1}$ & $\mathrm{NR}^{1}$ \\
\hline & Great difficulty & $\mathrm{NR}^{1}$ & $\mathrm{NR}^{1}$ & $\mathrm{NR}^{1}$ & $\mathrm{NR}^{1}$ \\
\hline & Some difficulty & Excess (+) & $\mathrm{NR}^{1}$ & $\mathrm{NR}^{1}$ & $\mathrm{NR}^{1}$ \\
\hline & No disability & Deficit $(+)$ & $\mathrm{NR}^{1}$ & $\mathrm{NR}^{1}$ & $\mathrm{NR}^{1}$ \\
\hline \multirow{2}{*}{ Gender } & Male & Deficit (-) & Excess (+) & Deficit (+) & Excess (-) \\
\hline & Female & Excess (+) & Deficit (-) & Excess (-) & Deficit $(+)$ \\
\hline \multirow{6}{*}{ Age range } & Up to 19 & Deficit (-) & Deficit (-) & $\mathrm{NR}^{1}$ & $\mathrm{NR}^{1}$ \\
\hline & 20 to 29 & $\mathrm{NR}^{1}$ & Deficit $(+)$ & $\mathrm{NR}^{1}$ & $\mathrm{NR}^{1}$ \\
\hline & 30 to 39 & $\mathrm{NR}^{1}$ & $\mathrm{NR}^{1}$ & $\mathrm{NR}^{1}$ & $\mathrm{NR}^{1}$ \\
\hline & 40 to 49 & $\mathrm{NR}^{1}$ & $\mathrm{NR}^{1}$ & $\mathrm{NR}^{1}$ & $\mathrm{NR}^{1}$ \\
\hline & 50 to 59 & $\mathrm{NR}^{1}$ & $\mathrm{NR}^{1}$ & $\mathrm{NR}^{1}$ & $\mathrm{NR}^{1}$ \\
\hline & More than 60 & Excess (+) & Excess (+) & Deficit (+) & Deficit (+) \\
\hline
\end{tabular}

${ }^{1}$ Not relevant. The standardized Pearson residual has a small contribution to the chi-square $\left(\chi^{2}\right)$ value

(+) Positive effect related to equity in the distribution of the number of residents

(-) Negative effect related to equity in the distribution of the number of residents Source: The author

Concerning the variable permanent mobility constraints, the excess of residents with some difficulty of walking or climbing stairs that live in the class A railway crossing surroundings is a positive effect to the vertical equity, since it corresponds to a vulnerable group 
which cannot walk long distances and for long periods. Therefore, it is expected that this social group distribution will be preferred along the best classified crossings. On the other hand, the deficit of residents with no disability that live around the class A railway crossings is also a positive effect to the vertical equity, since individuals from this group do not have any mobility constraints and can walk greater distances.

Regarding residents' gender distribution, for a positive effect to the vertical equity, an excess of men or women living around classes A and B railroad crossings or a deficit of men or women living around classes $\mathrm{C}$ and $\mathrm{D}$ is desired, and the contrary for a negative effect. Thus, an excess of women in class $\mathrm{A}$, an excess of men around class $\mathrm{B}$, a deficit of men in class $\mathrm{C}$ and a deficit of women around class $\mathrm{D}$ indicate a positive effect to the vertical equity. On the other hand, a deficit of men in class A, a deficit of women around class B, an excess of women in class $\mathrm{C}$ and an excess of men around class $\mathrm{D}$ indicate a negative effect to the vertical equity.

Similarly, a positive effect to the vertical equity regarding age involves an excess of residents up to 19 years old or more than 60 years old around classes A and B railroad crossings, or a deficit of residents up to 19 years old or more than 60 years old around classes C and D. Thus, the deficit of residents up to 19 years old in classes A and B indicate a negative effect. On the other hand, the deficit of residents aged between 20 and 29 in class B, the excess of residents aged more than 60 around classes $\mathrm{A}$ and $\mathrm{B}$ and the deficit of residents aged more than 60 in classes $\mathrm{C}$ and $\mathrm{D}$ indicate a positive effect to the vertical equity.

\subsection{Case study 02: Assessment of the community severance caused by Urban Streets}

Based on the data collected, the urban street network created and the delimited areas of influence, we selected a sample of urban streets and classified them. We also carried out the exploratory data analysis and chi-square $\left(\chi^{2}\right)$ tests of independence, and evaluated the standardized Pearson residuals, as detailed in the subsequent Subsections.

\subsubsection{Classification of the urban streets}

The urban street network of the study area was generated using the Open Street Map (OSM) database and the free software package Quantum GIS v.3.4.6. The resulting map comprised 13,329 segments of public urban streets, as represented in gray in Figure 5.5. Based on the resulting map, we selected a sample of segments of urban streets by simple random sampling. The sample size corresponded to $\mathrm{n}_{0}=100$ segments of urban streets (at a $95 \%$ confidence level and with a $10 \%$ margin of error), as highlighted in red in Figure 5.5. 
Figure 5.5 - Urban street network, in gray, and random sample $\left(\mathrm{n}_{0}=100\right.$ segments), highlighted in red

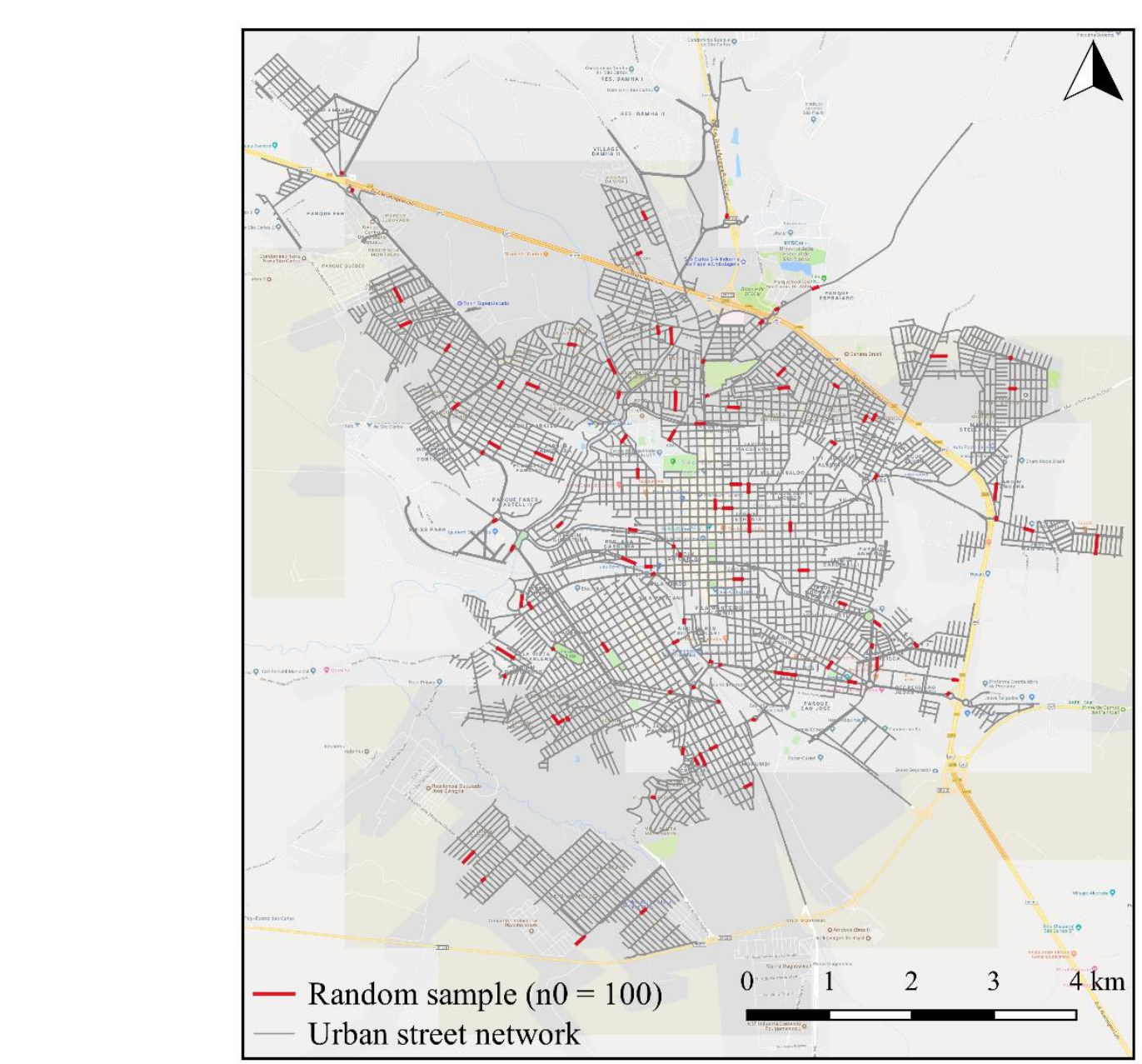

Source: The author

Thereby, considering the sample of segments of urban streets selected and the area of influence defined as a band of 400 meters, the segments were classified. The classification was carried out according to a qualitative assessment of the fourteen criteria described in Table 3.3 (Subsection 3.2.2). For each criterion, score values ranging from 0 to 1 were assigned. Score 0 corresponds to the worst mobility conditions for pedestrians and score 1 to the best conditions.

Criteria related to geometric design, pedestrian infrastructures, and maintenance conditions were evaluated through the analysis of the combined images of Google Street View and Google Maps. Although there is a limitation in this analysis, because some Google Street View images are from 2011, that is, some images are not current and may not represent the precise reality of the analyzed segments, the saving of time and financial resources, due to the great number of urban roads analyzed, and the ease of access to data justify the use of these image resources. The functional classification of the urban streets, which is another evaluation criterion, was also carried out with the help from the Google Maps images (and following the guidelines defined by DNIT (2010)), as shown in Figure 5.6. 
Figure 5.6 - Functional classification of the urban streets of São Carlos

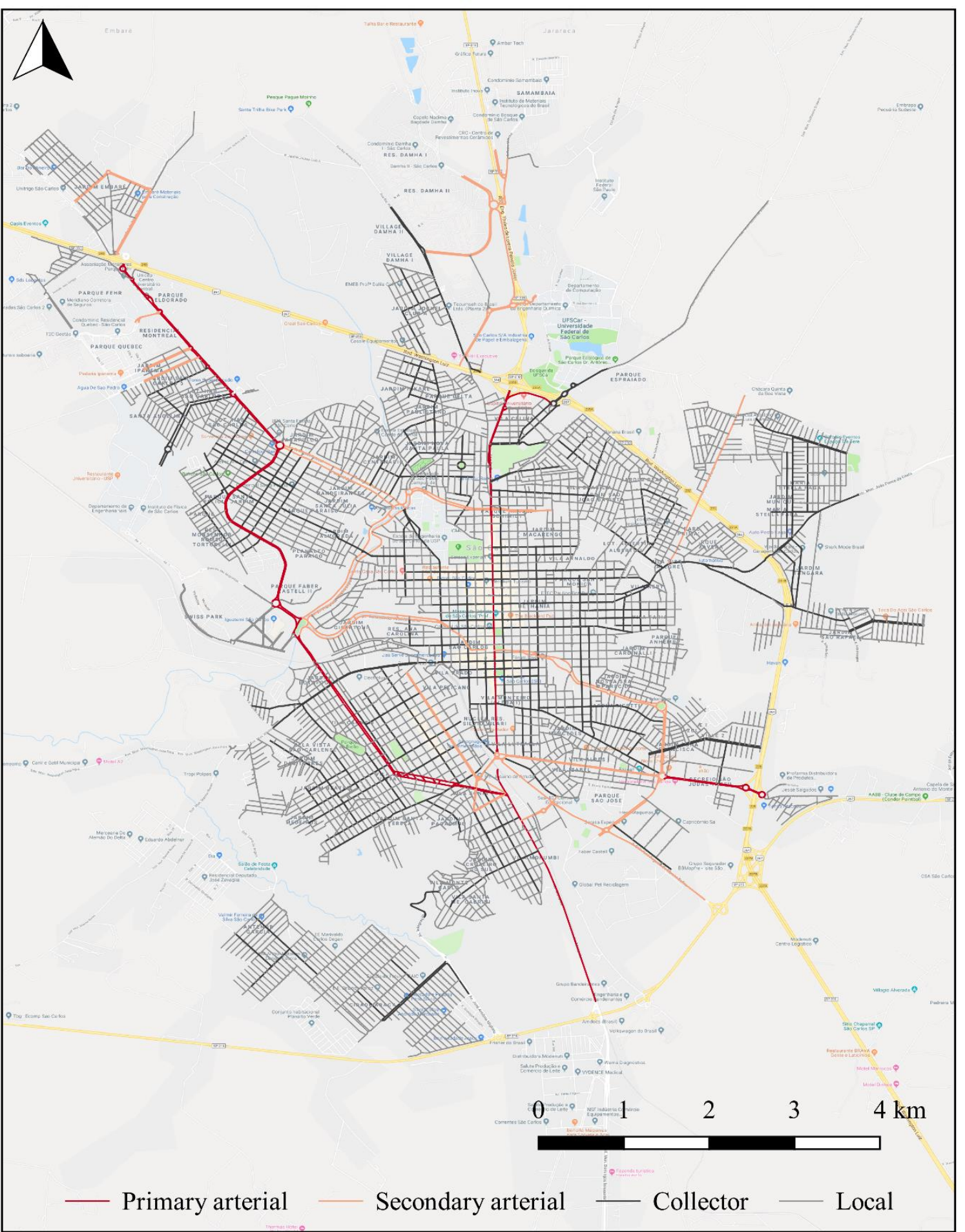

Source: The author

The public lighting criterion, which is also related to maintenance conditions was assessed by the quality of the lampposts surrounding the segments. The location plan of the city lampposts and its specifications was provided by the Municipal Secretariat of Public Services of São Carlos. 
Figure 5.7 - Crime occurrence per year (from 2010 to 2017)

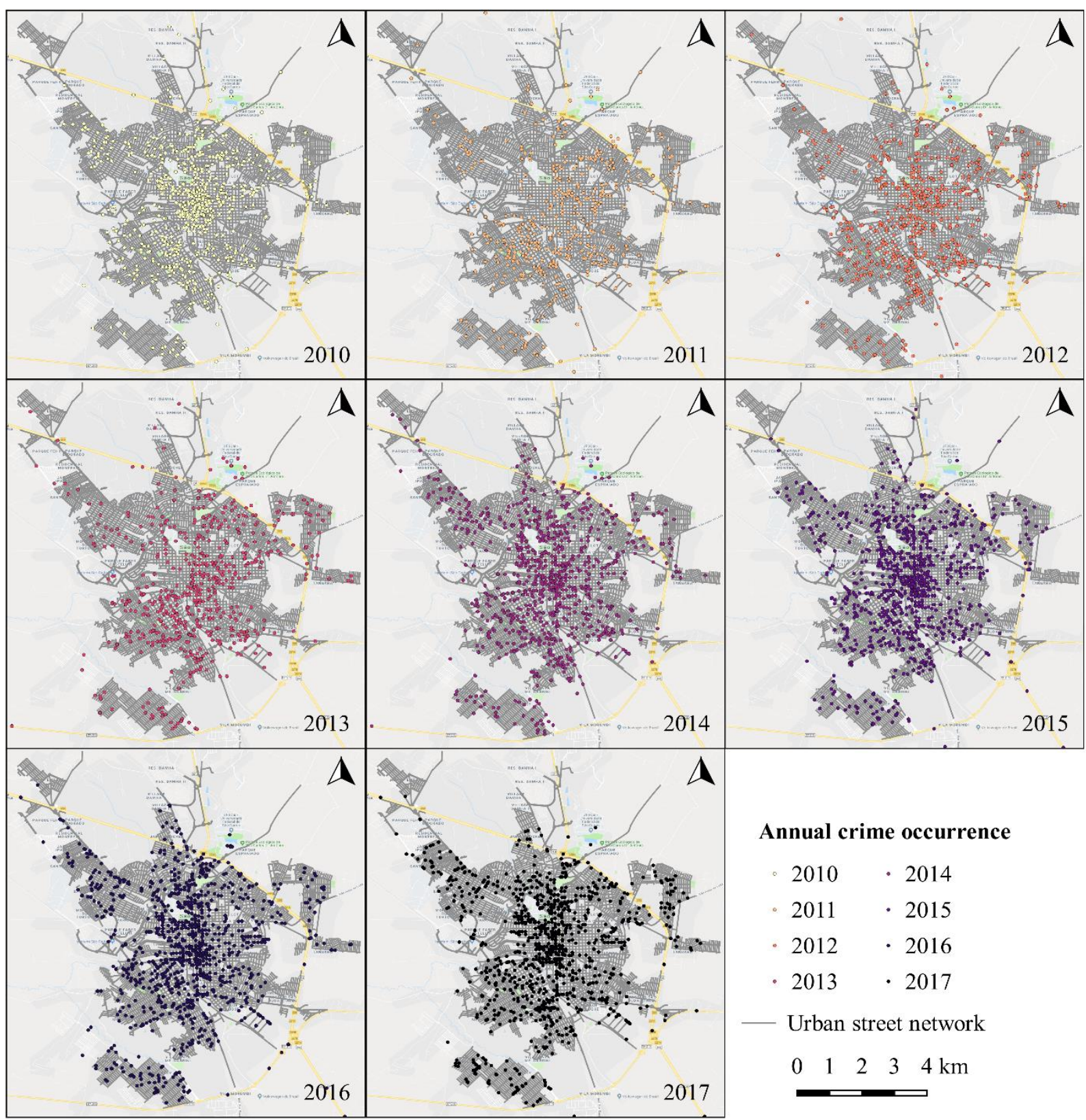

Source: Open data website of the Public Security Secretariat of São Paulo (in Portuguese: Secretaria de Segurança Pública de São Paulo - SSP/SP)

The evaluation of the criterion concerning safety was carried out based on the annual crime and death rates per 1000 inhabitants within the area of influence of the urban street segments sampled $\left(\mathrm{n}_{0}=100\right)$. In order to do so, we used data regarding the number of registered occurrences of crimes and deaths extracted from the open data website of the Public Security Secretariat of São Paulo. Part of the registered data presented the location by coordinates (longitude and latitude), another part presented only the address, or the intersecting streets, and another part of the data did not present any information of the location of the occurrence. Georeferencing of data by address or intersecting streets was conducted using the batch 
geocoding from the Google Earth Pro software. However, even using the Google Earth Pro software tools, the georeferencing of some of these occurrences was not achieved. Thus, we discarded part of the data due to the lack of location information and the impossibility of georeferencing the occurrences. Therefore, we created maps of registered occurrences of crimes and deaths whose georeferencing was reachable, as illustrated in Figure 5.7 and Figure 5.8.

Figure 5.8 - Death occurrence per year (from 2010 to 2017)

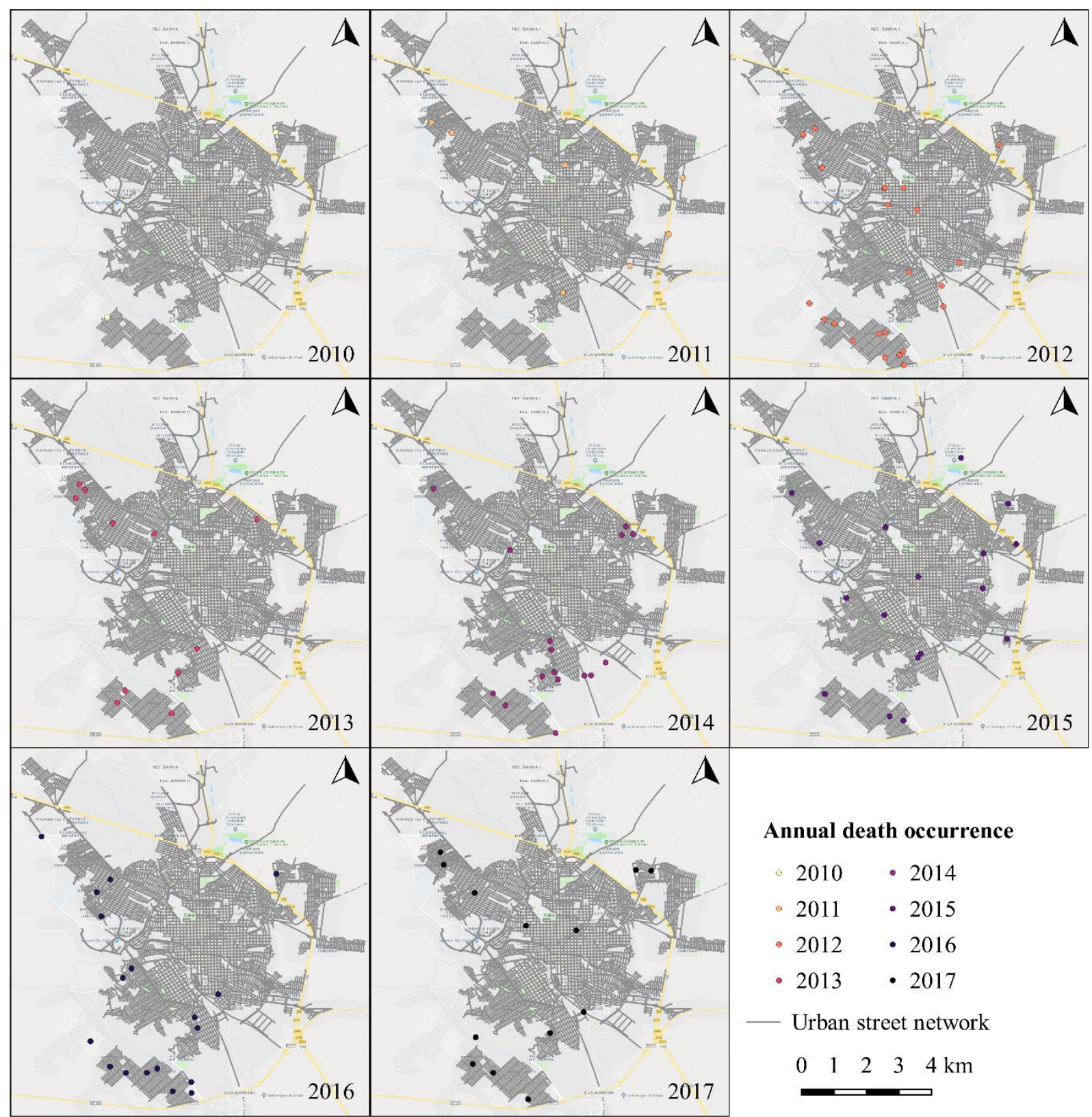

Source: Open data website of the Public Security Secretariat of São Paulo (in Portuguese: Secretaria de Segurança Pública de São Paulo - SSP/SP) 
Regarding the criterion related to population, we estimated the number of inhabitants from the area of influence using the statistical grid database. The scores assigned to the five levels of number of inhabitants were categorized into equal ranges, as indicated in Figure 5.9.

Figure 5.9 - Number of inhabitants within the areas of influence

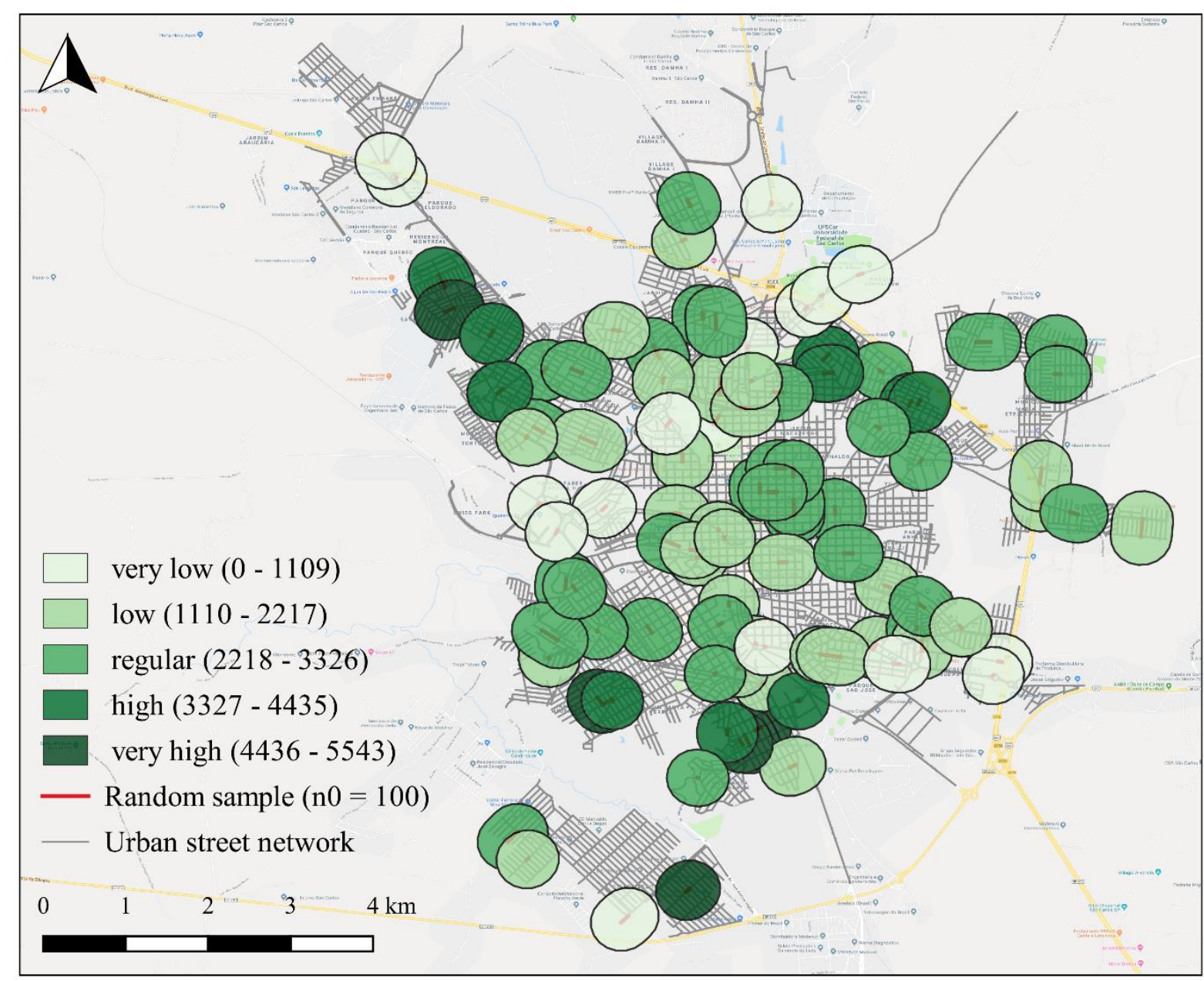

Source: The author

On the other hand, land use criterion was analyzed according to the land use map from the city Master Plan of 2002 provided by the Municipal Secretariat of Housing and Urban Development of São Carlos, as presented in Figure 5.10.

Having analyzed and calculated the criteria, we conducted the sum of all fourteen criteria and this sum resulted in the PeCUS index value for each segment of urban street. The value of the PeCUS index varies according to the quality of the conditions available for pedestrians to cross the segments of urban streets. Therefore, the PeCUS index also reflects, but inversely, the variation of community severance. 
Figure 5.10 - Land use map in the urban area of São Carlos

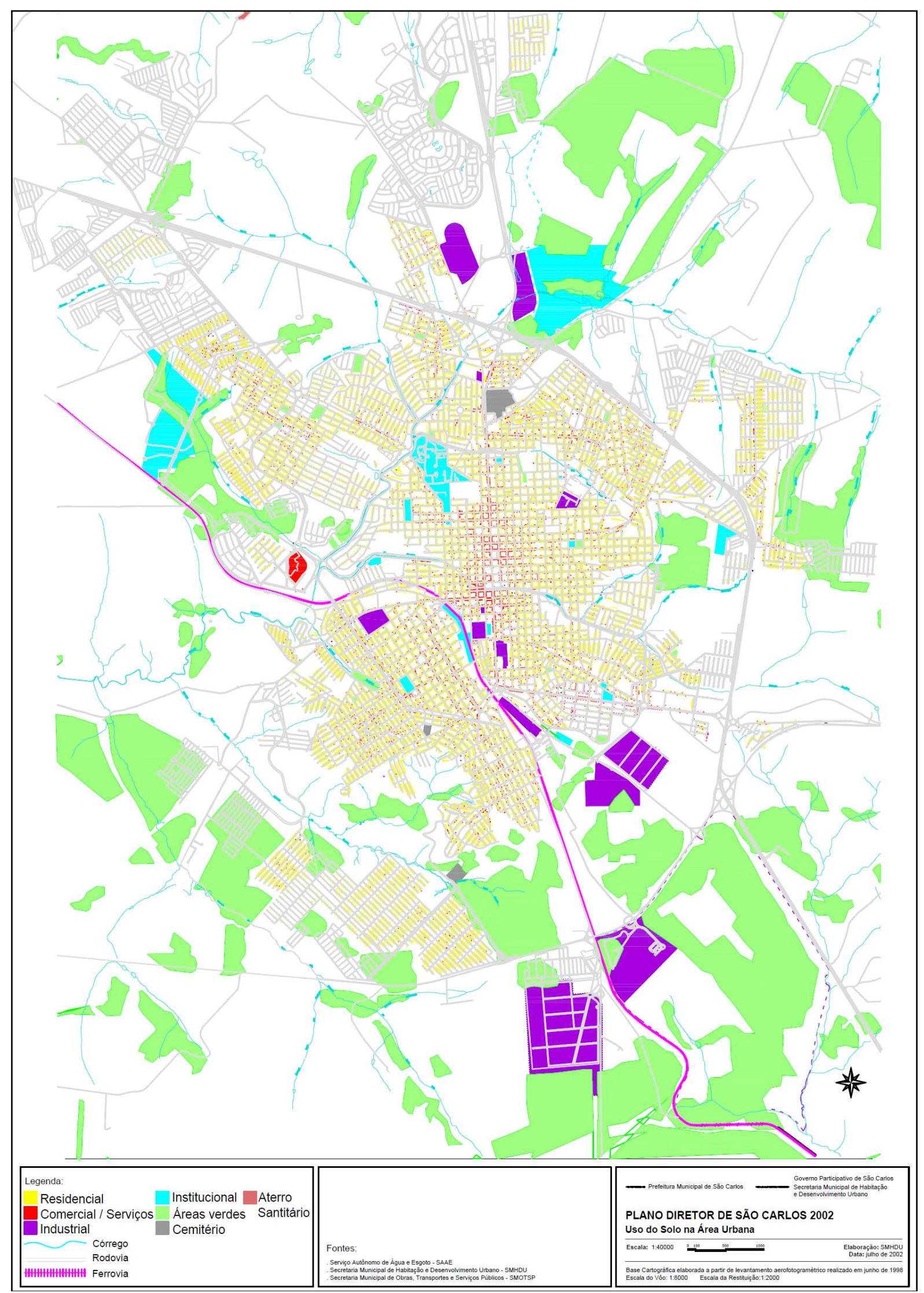

Source: Municipal Secretariat of Housing and Urban Development of São Carlos (in Portuguese: Secretaria Municipal de Habitação e Desenvolvimento Urbano), 2002 
Additionally, we conducted a cluster analysis to group the PeCUS index results into six classes, ranging from $\mathrm{A}$ to $\mathrm{F}$, using the $k$-means clustering algorithm from the IBM SPSS Statistics v.25 software. Class A corresponds to the best quality of pedestrian crossings and F corresponds to the worst evaluation. The number of segments grouped in each class of the PeCUS index is presented in Table 5.8. In addition, Table 5.9 contains the results for the highest and lowest $P e C U S$ index per class, as well as their respective scores for each criterion assessed.

Table 5.8 - Number of segments of urban street assigned per class

Source: The author

\begin{tabular}{ccccccc}
\hline Class & A & B & C & D & E & F \\
\hline Number of cases & 4 & 9 & 21 & 31 & 26 & 9 \\
\hline
\end{tabular}

Table 5.9 - Results of the highest and lowest values for the PeCUS index and their corresponding scores for each criterion assessed (indicated by segment's ID)

\begin{tabular}{|c|c|c|c|c|c|c|c|c|c|c|c|c|}
\hline \multirow{2}{*}{ Criterion } & \multicolumn{12}{|c|}{$\mathrm{ID}^{1}$} \\
\hline & 13062 & 332 & 335 & 12917 & 8235 & 1087 & 2969 & 9867 & 2422 & 5321 & 145 & 4546 \\
\hline Class & A & A & B & $\mathrm{B}$ & $\mathrm{C}$ & $\mathrm{C}$ & $\mathrm{D}$ & $\mathrm{D}$ & $\mathrm{E}$ & $\mathrm{E}$ & $\mathrm{F}$ & $\mathrm{F}$ \\
\hline$P e C U S$ index & 11.86 & 10.71 & 10.14 & 8.89 & 8.27 & 7.14 & 7.07 & 6.17 & 5.92 & 5.02 & 4.92 & 3.62 \\
\hline $\begin{array}{l}\text { Functional } \\
\text { classification }\end{array}$ & 0.67 & 0.67 & 0.67 & 0.67 & 0.33 & 0.67 & 1.00 & 1.00 & 1.00 & 1.00 & 0.00 & 1.00 \\
\hline Stream direction & 1.00 & 1.00 & 1.00 & 1.00 & 0.00 & 0.00 & 0.00 & 0.00 & 0.00 & 0.00 & 1.00 & 0.00 \\
\hline Number of lanes & 0.67 & 0.67 & 1.00 & 0.67 & 0.67 & 0.67 & 0.67 & 0.67 & 0.67 & 0.67 & 0.67 & 0.67 \\
\hline Zebra crossing & 0.50 & 0.50 & 0.50 & 0.50 & 0.50 & 0.00 & 0.00 & 0.00 & 0.00 & 0.00 & 0.00 & 0.00 \\
\hline $\begin{array}{l}\text { Zebra crossing } \\
\text { location }\end{array}$ & 0.67 & 0.67 & 0.67 & 0.00 & 0.67 & 0.00 & 0.00 & 0.00 & 0.00 & 0.00 & 0.00 & 0.00 \\
\hline $\begin{array}{c}\text { Pedestrian } \\
\text { visibility }\end{array}$ & 1.00 & 0.50 & 0.50 & 0.50 & 1.00 & 1.00 & 0.50 & 0.00 & 0.00 & 0.00 & 1.00 & 0.00 \\
\hline Mandatory stop & 1.00 & 0.60 & 0.00 & 0.60 & 0.20 & 0.00 & 0.20 & 0.60 & 0.20 & 0.40 & 0.00 & 0.00 \\
\hline Median & 1.00 & 1.00 & 1.00 & 1.00 & 0.50 & 1.00 & 1.00 & 1.00 & 1.00 & 1.00 & 1.00 & 1.00 \\
\hline Accessibility & 0.80 & 0.80 & 1.00 & 0.40 & 0.60 & 0.00 & 0.00 & 0.40 & 0.00 & 0.00 & 0.00 & 0.00 \\
\hline $\begin{array}{l}\text { Number of crimes } \\
\text { and deaths }\end{array}$ & 0.75 & 0.75 & 0.50 & 0.50 & 0.75 & 0.50 & 1.00 & 0.50 & 0.75 & 0.25 & 0.25 & 0.50 \\
\hline $\begin{array}{l}\text { Number of } \\
\text { inhabitants }\end{array}$ & 1.00 & 1.00 & 1.00 & 1.00 & 0.25 & 1.00 & 1.00 & 1.00 & 0.25 & 0.25 & 0.00 & 0.00 \\
\hline Public lighting & 0.80 & 0.80 & 0.80 & 0.80 & 0.80 & 0.80 & 0.20 & 0.00 & 0.80 & 0.20 & 0.00 & 0.20 \\
\hline Salubrity & 1.00 & 1.00 & 0.75 & 0.50 & 1.00 & 1.00 & 1.00 & 0.50 & 0.75 & 0.75 & 1.00 & 0.25 \\
\hline Land use & 1.00 & 0.75 & 0.75 & 0.75 & 1.00 & 0.50 & 0.50 & 0.50 & 0.50 & 0.50 & 0.00 & 0.00 \\
\hline
\end{tabular}

${ }^{1}$ Identification number of the segments of urban streets

Source: The author 
In order to estimate the number of residents within the area of influence of 400 meters, three subsamples were randomly selected from the original sample $\left(\mathrm{n}_{0}=100\right)$. The subsamples resulted in $\mathrm{n}_{1}=38$ segments, highlighted in blue in Figure 5.11(a), $\mathrm{n}_{2}=35$ segments, highlighted in green in Figure 5.11(b) and $n_{3}=37$ segments, highlighted in orange in Figure 5.11(c). This was done to avoid overlapping areas of influence in the sample units. The number of residents within the area of influence was estimated for each subsample, regarding the variables of range of monthly nominal income, permanent mobility constraints, gender and age.

Figure 5.11 - Subsample $01\left(\mathrm{n}_{1}=38\right.$ segments), highlighted in blue (a). Subsample $02\left(\mathrm{n}_{2}=35\right.$ segments), highlighted in green (b). Subsample 03 ( $n_{3}=37$ segments), highlighted in orange (c)

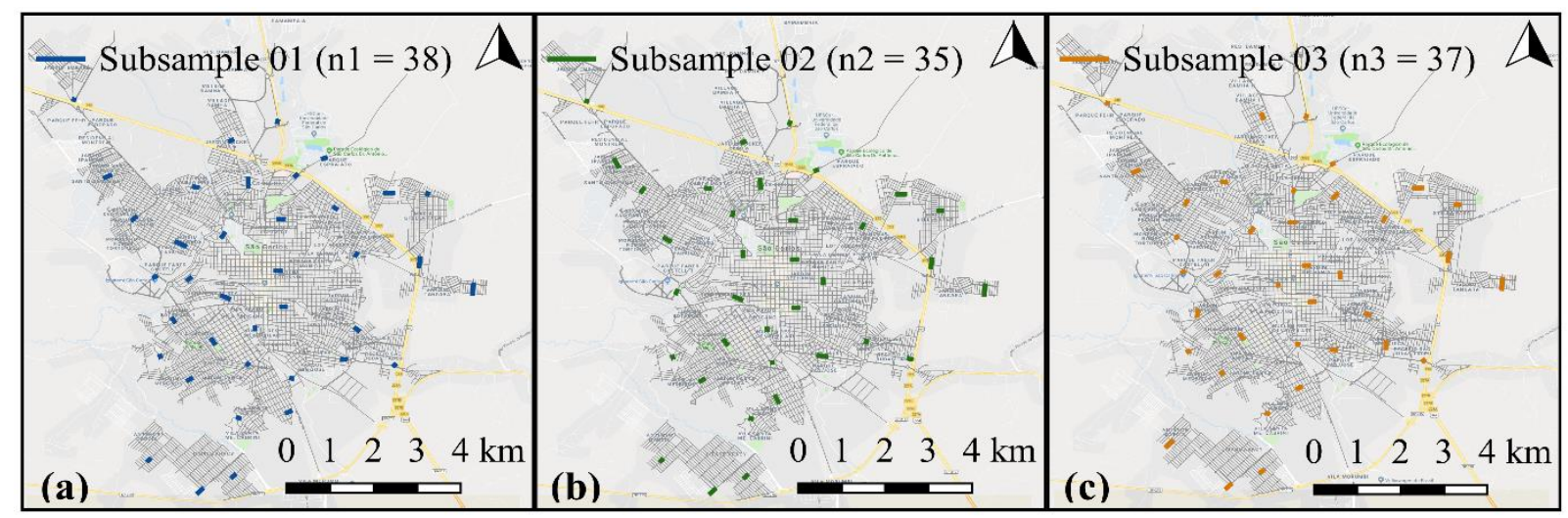

Source: The author

The size of each subsample should be greater than 57,555 inhabitants, at a $95 \%$ confidence level and with a $10 \%$ margin of error. Therefore, for each subsample the number of residents within the area of influence was estimated regarding the aforementioned variables. Table 5.10 presents the total population of the three subsamples regarding each variable.

Table 5.10 - Subsamples population per variable

\begin{tabular}{lccc}
\hline \multicolumn{1}{c}{ Variable } & $\begin{array}{c}\text { Subsample 01 } \\
\left(\mathrm{n}_{1}=38\right)\end{array}$ & $\begin{array}{c}\text { Subsample 02 } \\
\left(\mathrm{n}_{2}=35\right)\end{array}$ & $\begin{array}{c}\text { Subsample 03 } \\
\left(\mathrm{n}_{3}=37\right)\end{array}$ \\
\hline Range of monthly nominal income & 78,938 & 78,595 & 81,508 \\
\hline Permanent mobility constraints $^{1}$ & 78,938 & 78,600 & 81,514 \\
\hline Female age range $^{1}$ & 40,686 & 40,393 & 41,999 \\
\hline Male age range $^{1}$ & 38,449 & 38,453 & 39,848 \\
\hline
\end{tabular}

1 The combined population for female and male age ranges should be greater than 57,555

Source: The author 


\subsubsection{Exploratory data analysis}

The exploratory data analysis of the variables of the different databases studied enabled us to describe aspects and make inferences about the equity in the distribution of the number of residents in the urban streets surroundings.

For this reason, using the free software package Quantum GIS v.3.4.6, we calculated the distribution of inhabitants according to the class of the PeCUS index regarding residents' demographic characteristics, per subsample, as shown in Figure 5.12 to Figure 5.16.

Figure 5.12 indicates an overview of the distribution of the residents for each variable per class of the PeCUS index and by subsample, in absolute values. Figure 5.13 to Figure 5.16 provide an overview of the main categories in the classes of the PeCUS index, per variable and per subsample, in percentage values.

Figure 5.12 - Graph of the number of residents distributed by class of PeCUS index, for each subsample and for each variable

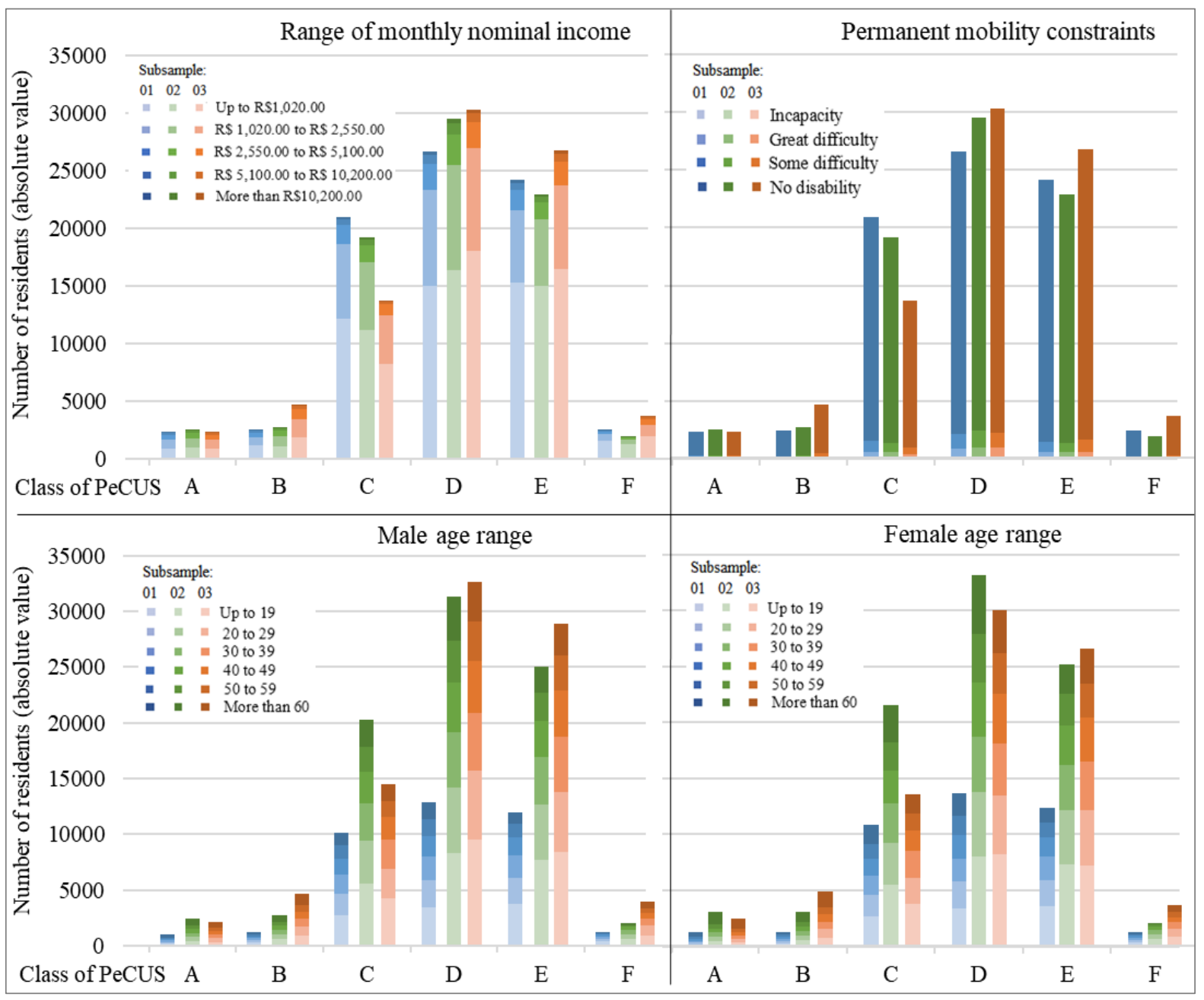

Source: The author 


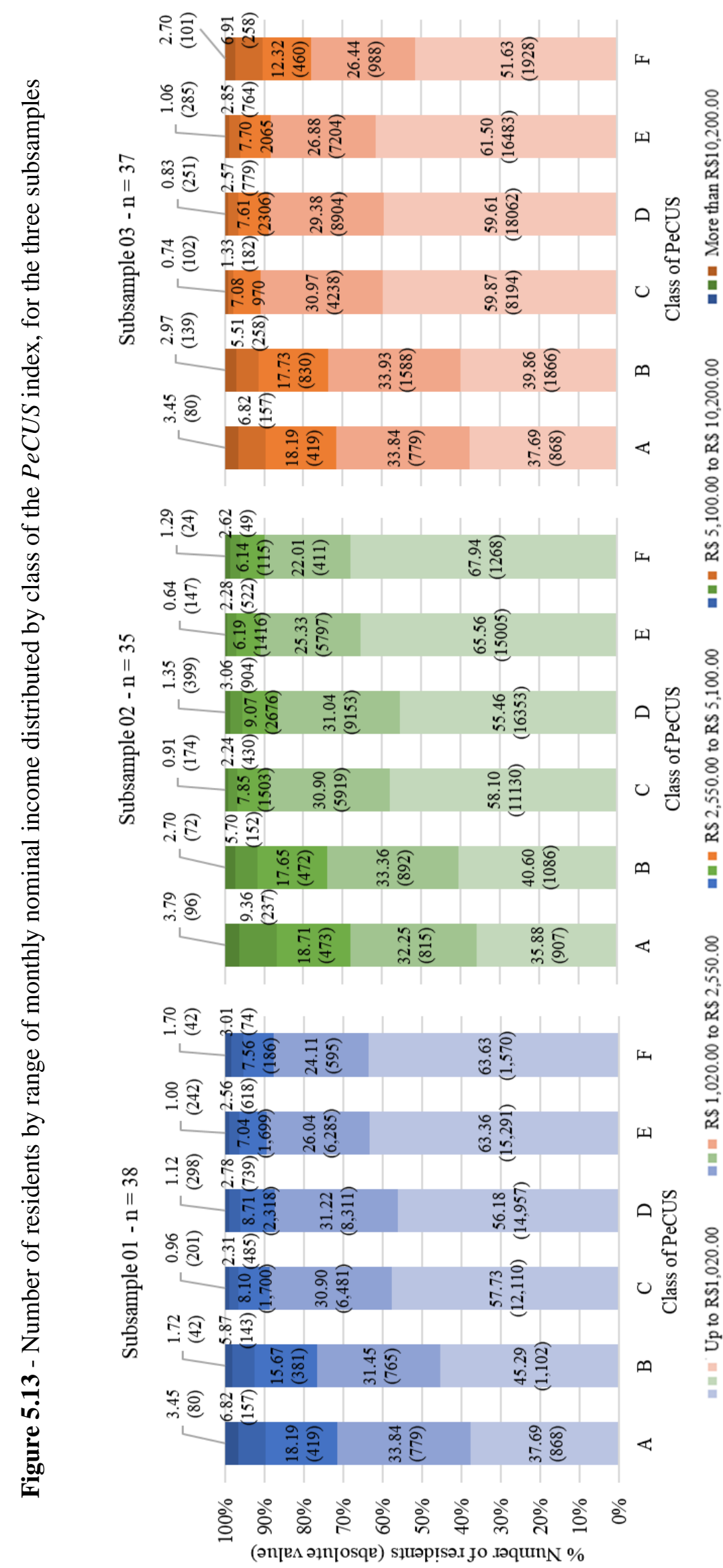




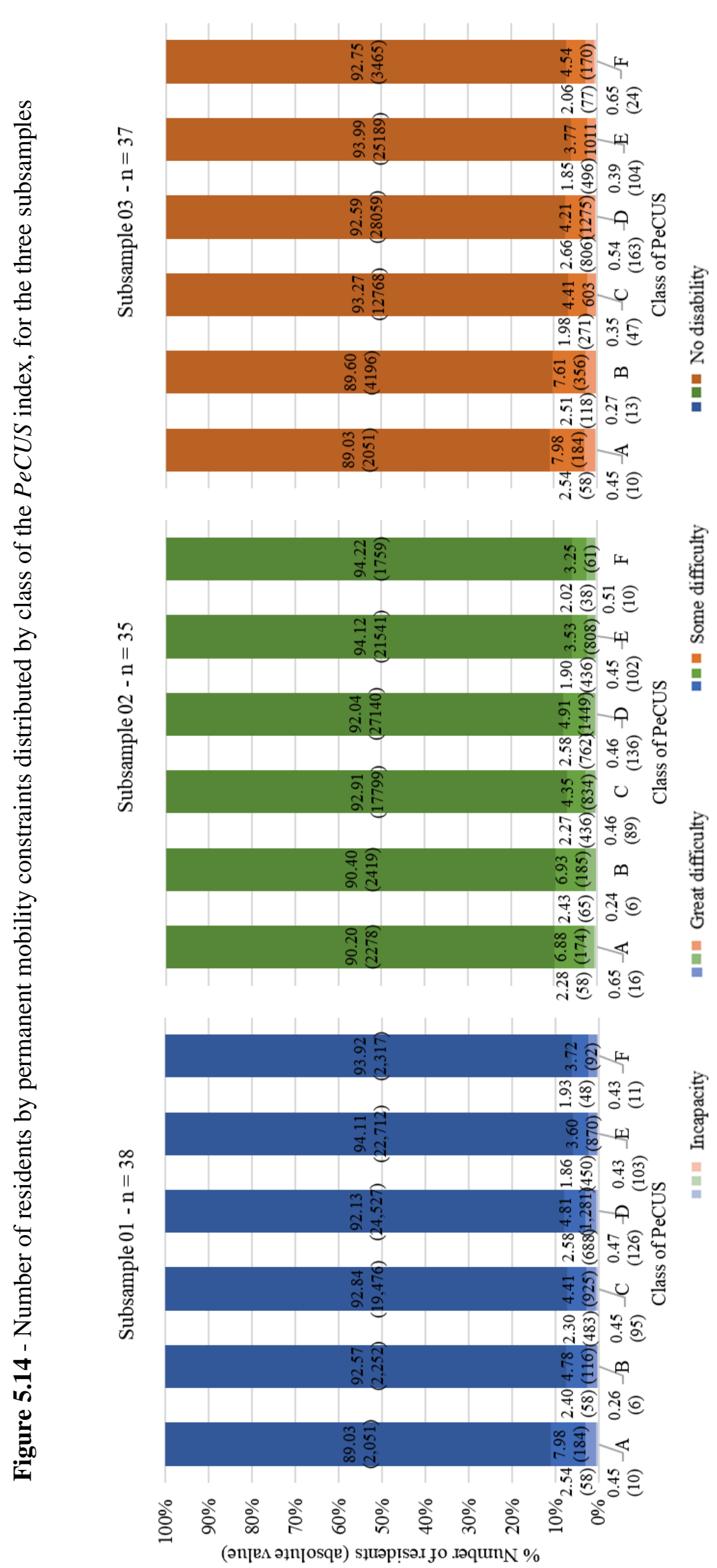




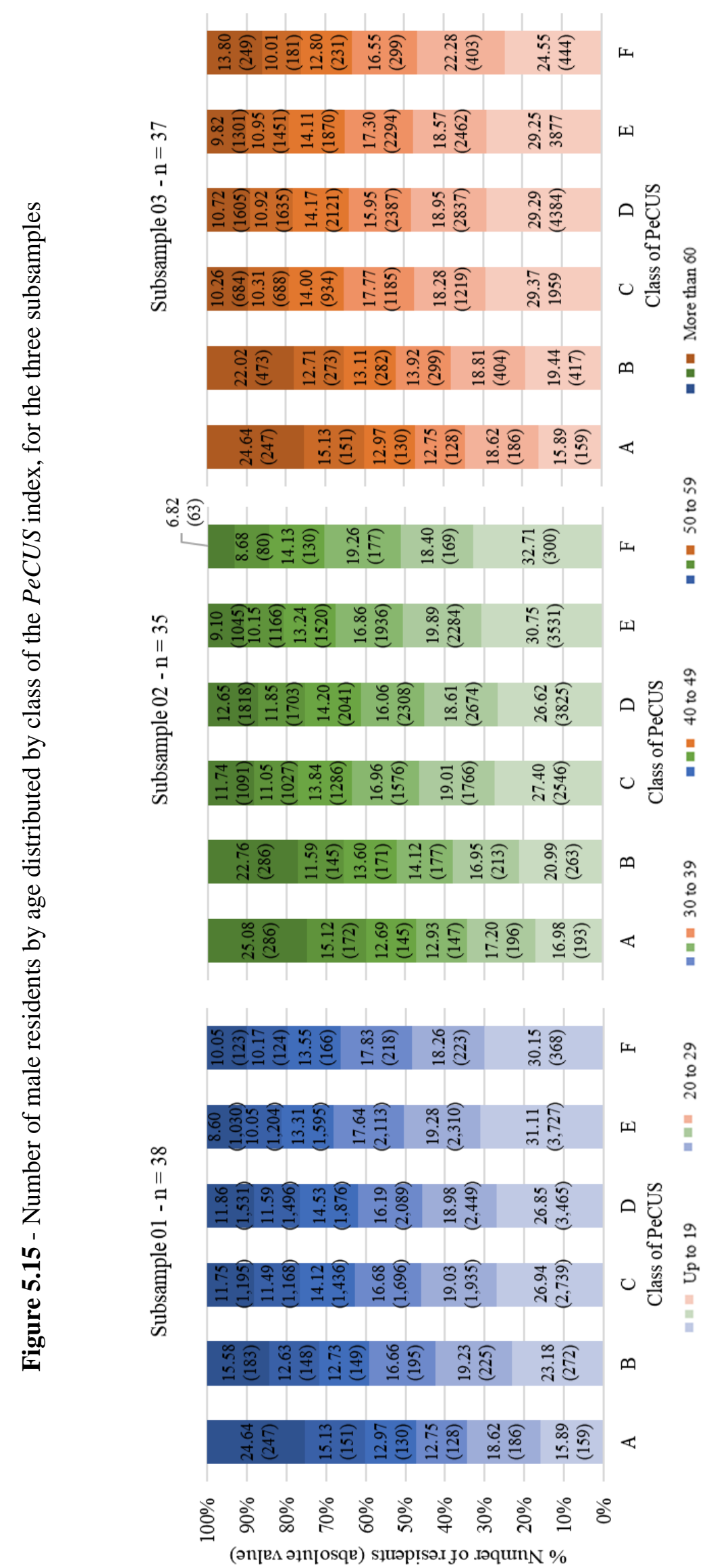




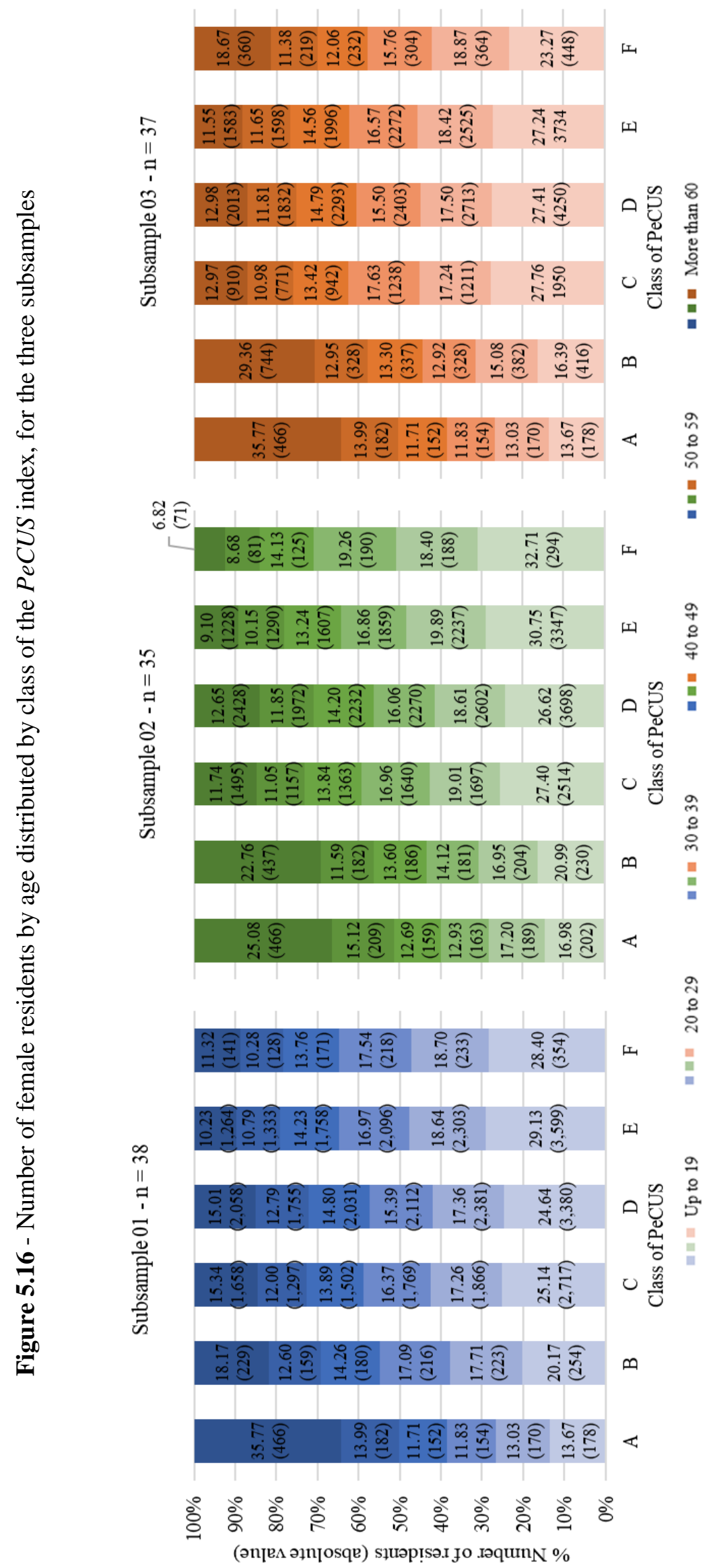


Figure 5.13 indicates that more than half of the residents in classes C, D, E and F have a monthly income below $\mathrm{R} \$ 1,020.00$, whereas the portion of the population with an income greater than $\mathrm{R} \$ 5,100.00$ that lives near classes A and B is about twice as large as the portion that lives in classes C, D, E and F. In Figure 5.14, it can be observed that around $11.0 \%$ of the population has some level of self-declared permanent mobility constraints. Furthermore, the proportion of residents with some difficulty in walking or climbing stairs without the help of another person is higher among the residents that live near class A. Moreover, most of the population that lives near class A streets are over 60 years old, and this proportion is higher among women (about 1/3) than among men (about 1/4) (as shown in Figure 5.16 and Figure 5.15, respectively). In addition, we can see in Figure 5.15 and Figure 5.16 that most residents in class $\mathrm{E}$ are aged up to 19 years old.

\subsubsection{Chi-square $\left(\chi^{2}\right)$ test of independence and standardized Pearson residuals}

The exploratory data analysis of the variables enabled us to describe aspects between the variables and make assumptions about the vertical equity in the distribution of the number of residents according to the distinct classes of the PeCUS index. However, it is not enough to validate the hypothesis of association between the variables or to identify the nature and the degree of dependence between the variables.

Thus, chi-square $\left(\chi^{2}\right)$ values were calculated for all subsamples by looking at the number of residents observed and expected in each of the classes of the PeCUS index when combined with the variables: ( $i$ ) number of residents by range of monthly nominal income; (ii) number of residents with self-declared permanent mobility constraints; (iii) number of male residents by age range and (iv) number of female residents by age range, as indicated in Table 5.11 to Table 5.14

All values calculated for the chi-square $\left(\chi^{2}\right)$ resulted in higher than the critical values of the chi-square $\left(\chi^{2}\right)$ distribution, considering their respective degrees of freedom, with a p-value less than 0.0250 (Table 5.11 to Table 5.14). Hence, the null hypothesis $\left(\mathrm{H}_{0}\right)$ was rejected at a level of significance of less than 0.0250 for all subsamples regarding each variable. Therefore, a possible association between the variables of classification and (i) number of residents by range of monthly nominal income; (ii) number of residents with self-declared permanent mobility constraints; (iii) number of male residents by age range and (iv) number of female residents by age range cannot be ruled out.

Additionally, we calculated the standardized Pearson residuals (Table 5.11 to Table 5.14) and found cells of the cross-classification tables with population values higher than 
expected, indicating excesses of residents with certain demographic characteristics living in the surroundings of specific classes of the PeCUS index. Analogously, we also found cells with less residents than expected, indicating deficits of residents.

Table 5.11 - Squared Pearson residuals $\left(\mathrm{PR}^{2}\right)$, standardized Pearson residuals (SPR) and chi-square $\left(\chi^{2}\right)$ test of independence between the variables of class of the PeCUS index and number of residents by range of monthly nominal income

\begin{tabular}{|c|c|c|c|c|c|c|c|c|}
\hline \multirow{3}{*}{\multicolumn{2}{|c|}{$\begin{array}{l}\text { Range of monthly } \\
\text { nominal income }\end{array}$}} & \multicolumn{6}{|c|}{ Class of $\mathrm{PeCUS}$} & \multirow{4}{*}{$\chi^{2}=\sum \mathrm{PR}^{2}$} \\
\hline & & \multirow{3}{*}{$\begin{array}{c}\mathrm{A} \\
\mathrm{PR}^{2} \\
\mathrm{SPR}\end{array}$} & \multirow{3}{*}{$\begin{array}{c}\mathrm{B} \\
\mathrm{PR}^{2} \\
\mathrm{SPR}\end{array}$} & \multirow{3}{*}{$\begin{array}{c}\mathrm{C} \\
\mathrm{PR}^{2} \\
\mathrm{SPR}\end{array}$} & \multirow{3}{*}{$\begin{array}{c}\mathrm{D} \\
\mathrm{PR}^{2} \\
\mathrm{SPR}\end{array}$} & \multirow{3}{*}{$\begin{array}{c}\mathrm{E} \\
\mathrm{PR}^{2} \\
\mathrm{SPR}\end{array}$} & \multirow{3}{*}{$\begin{array}{c}\mathrm{F} \\
\mathrm{PR}^{2} \\
\mathrm{SPR}\end{array}$} & \\
\hline & & & & & & & & \\
\hline & & & & & & & & \\
\hline \multirow{10}{*}{ 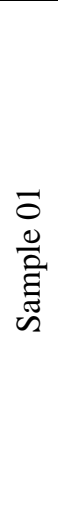 } & Up to & 165.5966 & 69.1635 & 0.6196 & 17.6514 & 112.7593 & 12.7704 & \multirow{10}{*}{$\begin{array}{c}1,398.3285 \\
\text { p-value }= \\
0.0000 \\
\text { (20 degrees } \\
\text { of freedom) }\end{array}$} \\
\hline & $\mathrm{R} \$ 1,020.00$ & -20.19 & -13.06 & -1.42 & -7.98 & +19.70 & +5.61 & \\
\hline & $\mathrm{R} \$ 1,020.00$ to & 15.3687 & 3.4558 & 15.7304 & 29.5281 & 93.2165 & 23.5339 & \\
\hline & $\mathrm{R} \$ 2,550.00$ & +4.74 & +2.25 & +5.51 & +7.94 & -13.79 & -5.87 & \\
\hline & $\mathrm{R} \$ 2,550.00$ to & 254.9171 & 147.4206 & 3.7270 & 1.4601 & 59.9809 & 2.5504 & \\
\hline & $\mathrm{R} \$ 5,100.00$ & +16.94 & +12.89 & -2.36 & +1.55 & -9.72 & -1.70 & \\
\hline & \multirow{2}{*}{$\begin{array}{l}\mathrm{R} \$ 5,100.00 \text { to } \\
\mathrm{R} \$ 10,200.00\end{array}$} & 132.1241 & 81.4288 & 18.3493 & 0.0905 & 5.2623 & 0.3471 & \\
\hline & & +11.83 & +9.30 & -5.07 & -0.37 & -2.79 & +0.61 & \\
\hline & \multirow{2}{*}{$\begin{array}{c}\text { More than } \\
\mathrm{R} \$ 10,200.00\end{array}$} & 107.0355 & 6.9890 & 6.3769 & 0.1772 & 4.2129 & 6.4847 & \\
\hline & & +10.56 & +2.70 & -2.96 & -0.52 & -2.48 & +2.60 & \\
\hline \multirow{10}{*}{ 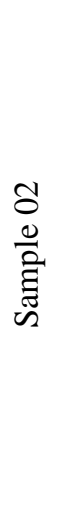 } & Up to & 216.3650 & 142.3730 & 0.0377 & 38.1682 & 212.6371 & 30.3739 & \multirow{10}{*}{$\begin{array}{c}2,394.4367 \\
\text { p-value }= \\
0.0000 \\
\text { (20 degrees } \\
\text { of freedom) }\end{array}$} \\
\hline & $\mathrm{R} \$ 1,020.00$ & -23.13 & -18.78 & -0.35 & -12.09 & +26.79 & +8.63 & \\
\hline & $\mathrm{R} \$ 1,020.00$ to & 7.7861 & 15.4338 & 17.8766 & 32.5031 & 120.0926 & 33.4140 & \\
\hline & $\mathrm{R} \$ 2,550.00$ & +3.37 & +4.75 & +5.78 & +8.57 & -15.47 & -6.96 & \\
\hline & $\mathrm{R} \$ 2,550.00$ to & 313.2668 & 266.1581 & 8.6695 & 12.8815 & 140.4435 & 11.9326 & \\
\hline & $\mathrm{R} \$ 5,100.00$ & +18.80 & +17.35 & -3.54 & +4.75 & -14.71 & -3.65 & \\
\hline & \multirow{2}{*}{$\begin{array}{l}\mathrm{R} \$ 5,100.00 \text { to } \\
\mathrm{R} \$ 10,200.00\end{array}$} & 359.5715 & 70.7999 & 29.7629 & 2.1820 & 31.8836 & 0.5693 & \\
\hline & & +19.56 & +8.69 & -6.37 & +1.90 & -6.81 & -0.78 & \\
\hline & \multirow{2}{*}{$\begin{array}{l}\text { More than } \\
\mathrm{R} \$ 10,200.00\end{array}$} & 151.1753 & 54.4155 & 10.5549 & 9.5947 & 53.2490 & 0.2648 & \\
\hline & & +12.57 & +7.55 & -3.76 & +3.94 & -8.72 & +0.52 & \\
\hline \multirow{10}{*}{ 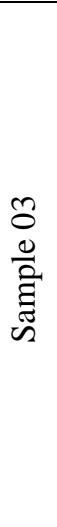 } & Up to & 154.0448 & 141.6954 & 0.0109 & 36.8381 & 215.6863 & 30.7090 & \multirow{10}{*}{$\begin{array}{c}3,384.0618 \\
\text { p-value }= \\
0.0000 \\
\text { (20 degrees } \\
\text { of freedom) }\end{array}$} \\
\hline & $\mathrm{R} \$ 1,020.00$ & -19.27 & -18.72 & -0.19 & -11.87 & +26.97 & +8.67 & \\
\hline & $\mathrm{R} \$ 1,020.00$ to & 13.3330 & 159.6305 & 98.6148 & 20.0949 & 13.2221 & 6.0747 & \\
\hline & $\mathrm{R} \$ 2,550.00$ & +4.42 & +15.45 & -13.31 & +6.67 & -5.25 & +3.00 & \\
\hline & $\mathrm{R} \$ 2,550.00$ to & 228.2192 & 683.2526 & 169.3245 & 18.9873 & 13.1801 & 131.0956 & \\
\hline & $\mathrm{R} \$ 5,100.00$ & +16.06 & +28.07 & -15.32 & -5.70 & -4.60 & +12.23 & \\
\hline & \multirow{2}{*}{$\begin{array}{c}\mathrm{R} \$ 5,100.00 \text { to } \\
\mathrm{R} \$ 10,200.00\end{array}$} & 111.5908 & 169.1201 & 201.4427 & 7.5114 & 0.0125 & 297.5580 & \\
\hline & & +10.88 & +13.54 & -16.20 & -3.47 & +0.14 & +17.86 & \\
\hline & \multirow{2}{*}{$\begin{array}{l}\text { More than } \\
\mathrm{R} \$ 10,200.00\end{array}$} & 97.5429 & 181.0307 & 47.7966 & 24.4732 & 1.1420 & 110.8272 & \\
\hline & & +10.08 & +13.88 & -7.82 & -6.21 & -1.30 & +10.80 & \\
\hline
\end{tabular}

Note: PR $^{2}$ - Squared Pearson residual; SPR - Standardized Pearson residual Source: The author 
Table 5.12 - Squared Pearson residuals $\left(\mathrm{PR}^{2}\right)$, standardized Pearson residuals (SPR) and chi-square $\left(\chi^{2}\right)$ test of independence between the variables of class of the PeCUS index and number of residents with self-declared permanent mobility constraints

\begin{tabular}{|c|c|c|c|c|c|c|c|c|}
\hline \multirow{3}{*}{\multicolumn{2}{|c|}{$\begin{array}{l}\text { Permanent mobility } \\
\text { constraints }\end{array}$}} & \multicolumn{6}{|c|}{ Class of $\mathrm{PeCUS}$} & \multirow{4}{*}{$\chi^{2}=\sum \mathrm{PR}^{2}$} \\
\hline & & \multirow{3}{*}{$\begin{array}{c}\mathrm{A} \\
\mathrm{PR}^{2} \\
\mathrm{SPR}\end{array}$} & \multirow{3}{*}{$\begin{array}{c}\mathrm{B} \\
\mathrm{PR}^{2} \\
\mathrm{SPR}\end{array}$} & \multirow{3}{*}{$\begin{array}{c}\mathrm{C} \\
\mathrm{PR}^{2} \\
\mathrm{SPR}\end{array}$} & \multirow{3}{*}{$\begin{array}{c}\mathrm{D} \\
\mathrm{PR}^{2} \\
\mathrm{SPR}\end{array}$} & \multirow{3}{*}{$\begin{array}{c}\mathrm{E} \\
\mathrm{PR}^{2} \\
\mathrm{SPR} \\
\end{array}$} & \multirow{3}{*}{$\begin{array}{c}\mathrm{F} \\
\mathrm{PR}^{2} \\
\mathrm{SPR} \\
\end{array}$} & \\
\hline & & & & & & & & \\
\hline & & & & & & & & \\
\hline \multirow{8}{*}{ 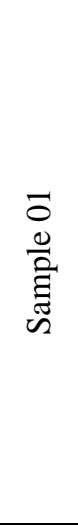 } & \multirow{2}{*}{ Incapacity } & 0.0009 & 1.8407 & 0.0305 & 0.4806 & 0.1861 & 0.0141 & \multirow{8}{*}{$\begin{array}{c}159.4212 \\
\mathrm{p} \text {-value }= \\
0.0000 \\
(15 \text { degrees } \\
\text { of freedom })\end{array}$} \\
\hline & & +0.03 & -1.38 & +0.20 & +0.85 & -0.52 & -0.12 & \\
\hline & \multirow{2}{*}{$\begin{array}{c}\text { Great } \\
\text { difficulty }\end{array}$} & 0.7906 & 0.1936 & 0.1610 & 12.2227 & 16.8825 & 1.2089 & \\
\hline & & +0.91 & +0.45 & +0.47 & +4.34 & -4.99 & -1.13 & \\
\hline & \multirow{2}{*}{$\begin{array}{c}\text { Some } \\
\text { difficulty }\end{array}$} & 67.5376 & 0.8200 & 0.0115 & 10.7127 & 34.2594 & 2.5530 & \\
\hline & & +8.53 & +0.94 & +0.13 & +4.11 & -7.18 & -1.66 & \\
\hline & \multirow{2}{*}{ No disability } & 3.7166 & 0.0295 & 0.0096 & 1.7033 & 3.7779 & 0.2779 & \\
\hline & & -7.34 & -0.65 & -0.43 & -6.02 & +8.76 & +2.01 & \\
\hline \multirow{8}{*}{ 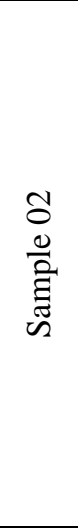 } & \multirow{2}{*}{ Incapacity } & 1.9515 & 2.7080 & 0.0203 & 0.0155 & 0.0745 & 0.1221 & \multirow{8}{*}{$\begin{array}{c}176.2151 \\
\mathrm{p} \text {-value }= \\
0.0000 \\
\text { (15 degrees } \\
\text { of freedom) }\end{array}$} \\
\hline & & +1.42 & -1.68 & +0.16 & +0.16 & -0.33 & +0.35 & \\
\hline & Great & 0.0002 & 0.2639 & 0.0055 & 11.8494 & 14.3898 & 0.5774 & \\
\hline & difficulty & -0.01 & +0.53 & -0.09 & +4.41 & -4.56 & -0.78 & \\
\hline & Some & 32.9237 & 36.3061 & 0.5554 & 13.2354 & 44.9493 & 6.1785 & \\
\hline & difficulty & +5.97 & +6.27 & -0.88 & +4.71 & -8.15 & -2.57 & \\
\hline & \multirow{2}{*}{ No disability } & 1.8353 & 1.6560 & 0.0273 & 1.8136 & 4.3468 & 0.4095 & \\
\hline & & -5.13 & -4.88 & +0.71 & -6.35 & +9.23 & +2.41 & \\
\hline \multirow{8}{*}{ 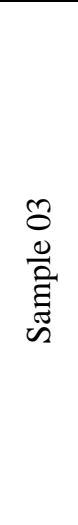 } & \multirow{2}{*}{ Incapacity } & 0.0015 & 3.1429 & 2.9160 & 6.1694 & 1.9148 & 3.4407 & \multirow{8}{*}{$\begin{array}{c}282.6249 \\
\text { p-value }= \\
0.0000 \\
\text { (15 degrees } \\
\text { of freedom) }\end{array}$} \\
\hline & & +0.04 & -1.83 & -1.88 & +3.14 & -1.69 & +1.90 & \\
\hline & \multirow{2}{*}{$\begin{array}{c}\text { Great } \\
\text { difficulty }\end{array}$} & 0.9224 & 1.5718 & 4.1892 & 23.8044 & 18.1616 & 0.5199 & \\
\hline & & +0.99 & +1.31 & -2.27 & +6.23 & -5.26 & -0.75 & \\
\hline & \multirow{2}{*}{$\begin{array}{c}\text { Some } \\
\text { difficulty }\end{array}$} & 66.3249 & 108.2797 & 0.0027 & 2.9854 & 25.0145 & 0.1387 & \\
\hline & & +8.45 & +10.96 & -0.06 & -2.23 & -6.24 & +0.39 & \\
\hline & \multirow{2}{*}{ No disability } & 3.7151 & 5.4802 & 0.1999 & 0.3052 & 3.4144 & 0.0095 & \\
\hline & & -7.34 & -9.05 & +1.84 & -2.62 & +8.46 & -0.37 & \\
\hline
\end{tabular}

Note: PR $^{2}$ - Squared Pearson residual; SPR - Standardized Pearson residual

Source: The author 
Table 5.13 - Squared Pearson residuals $\left(\mathrm{PR}^{2}\right)$, standardized Pearson residuals (SPR) and chi-square $\left(\chi^{2}\right)$ test of independence between the variables of class of the PeCUS index and number of male residents by age range

\begin{tabular}{|c|c|c|c|c|c|c|c|c|}
\hline \multirow{3}{*}{\multicolumn{2}{|c|}{ Male age range }} & \multicolumn{6}{|c|}{ Class of $P e C U S$} & \multirow{4}{*}{$\chi^{2}=\sum \mathrm{PR}^{2}$} \\
\hline & & A & B & $\mathrm{C}$ & $\mathrm{D}$ & $\mathrm{E}$ & $\mathrm{F}$ & \\
\hline & & $\mathrm{PR}^{2}$ & $\mathrm{PR}^{2}$ & $\mathrm{PR}^{2}$ & $\mathrm{PR}^{2}$ & $\mathrm{PR}^{2}$ & $\mathrm{PR}^{2}$ & \\
\hline & & SPR & SPR & SPR & SPR & SPR & SPR & \\
\hline \multirow{12}{*}{ 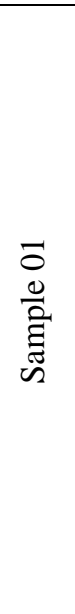 } & \multirow{2}{*}{ Up to 19} & 51.8167 & 9.3942 & 3.4365 & 5.1964 & 44.0890 & 2.2003 & \multirow{12}{*}{$\begin{array}{c}440.9800 \\
\mathrm{p}-\mathrm{value}= \\
0.0000 \\
(25 \text { degrees of } \\
\text { freedom })\end{array}$} \\
\hline & & -8.59 & -3.67 & -2.55 & -3.29 & +9.43 & +1.78 & \\
\hline & \multirow{2}{*}{20 to 29} & 0.1024 & 0.0186 & 0.0058 & 0.0488 & 0.3080 & 0.4161 & \\
\hline & & -0.36 & +0.15 & -0.10 & -0.30 & +0.74 & -0.73 & \\
\hline & \multirow{2}{*}{30 to 39} & 9.5290 & 0.0057 & 0.0279 & 2.4011 & 5.6742 & 0.8591 & \\
\hline & & -3.43 & -0.08 & -0.21 & -2.08 & +3.15 & +1.03 & \\
\hline & \multirow{2}{*}{40 to 49} & 0.6462 & 1.1869 & 0.2962 & 3.5293 & 3.1252 & 0.1195 & \\
\hline & & -0.88 & -1.19 & +0.68 & +2.48 & -2.30 & -0.38 & \\
\hline & \multirow{2}{*}{50 to 59} & 14.1266 & 2.2480 & 0.9603 & 2.1168 & 13.2168 & 1.0874 & \\
\hline & & +4.04 & +1.62 & +1.21 & +1.89 & -4.65 & -1.12 & \\
\hline & \multirow{2}{*}{$\begin{array}{l}\text { More than } \\
60\end{array}$} & 161.1612 & 19.9674 & 2.7021 & 4.9905 & 72.5139 & 1.4559 & \\
\hline & & +13.65 & +4.82 & +2.03 & +2.91 & -10.89 & -1.30 & \\
\hline \multirow{12}{*}{ 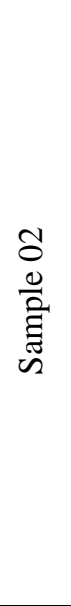 } & \multirow{2}{*}{ Up to 19} & 47.3952 & 20.5191 & 0.3371 & 6.2204 & 38.0352 & 8.2382 & \multirow{12}{*}{$\begin{array}{c}588.50284 \\
\mathrm{p}-\mathrm{value}= \\
0.0000 \\
(25 \text { degrees of } \\
\text { freedom })\end{array}$} \\
\hline & & -8.22 & -5.42 & -0.78 & -3.71 & +8.66 & +3.42 & \\
\hline & \multirow{2}{*}{20 to 29} & 1.9176 & 2.7568 & 0.0019 & 1.0955 & 4.9793 & 0.1658 & \\
\hline & & -1.56 & -1.88 & +0.06 & -1.47 & +2.96 & -0.46 & \\
\hline & \multirow{2}{*}{30 to 39} & 8.5415 & 4.1114 & 1.5247 & 1.2323 & 1.2686 & 4.4422 & \\
\hline & & -3.25 & -2.26 & +1.55 & -1.53 & +1.47 & 2.33 & \\
\hline & \multirow{2}{*}{40 to 49} & 0.9495 & 0.0241 & 0.0409 & 2.0383 & 2.2643 & 0.0886 & \\
\hline & & -1.07 & -0.17 & +0.25 & +1.94 & -1.93 & +0.32 & \\
\hline & \multirow{2}{*}{50 to 59} & 15.9664 & 0.2025 & 0.1034 & 6.1118 & 10.5461 & 5.0672 & \\
\hline & & +4.30 & +0.49 & -0.39 & +3.31 & -4.11 & -2.42 & \\
\hline & \multirow{2}{*}{$\begin{array}{l}\text { More than } \\
\quad 60\end{array}$} & 165.1911 & 123.4563 & 0.2769 & 6.2512 & 77.0939 & 20.0476 & \\
\hline & & +13.90 & +12.04 & -0.64 & +3.37 & -11.17 & -4.83 & \\
\hline \multirow{12}{*}{ 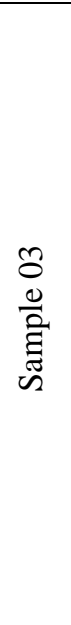 } & \multirow{2}{*}{ Up to 19} & 53.8531 & 58.5371 & 3.2164 & 6.2199 & 5.0905 & 8.5828 & \multirow{12}{*}{$\begin{array}{c}626.8240 \\
\mathrm{p}-\mathrm{value}= \\
0.0000 \\
(25 \text { degrees of } \\
\text { freedom })\end{array}$} \\
\hline & & -8.77 & -9.28 & +2.32 & 3.73 & +3.26 & -3.54 & \\
\hline & \multirow{2}{*}{20 to 29} & 0.0277 & 0.0019 & 1.1242 & 0.0825 & 0.5368 & 11.3247 & \\
\hline & & -0.19 & -0.05 & -1.29 & +0.40 & -1.00 & +3.82 & \\
\hline & \multirow{2}{*}{30 to 39} & 8.6794 & 8.9539 & 6.0903 & 3.1882 & 4.6529 & 0.0001 & \\
\hline & & -3.27 & -3.37 & +2.96 & -2.47 & +2.89 & +0.01 & \\
\hline & \multirow{2}{*}{40 to 49} & 0.7225 & 1.1442 & 0.0037 & 0.4146 & 0.1830 & 1.7688 & \\
\hline & & -0.93 & -1.19 & +0.07 & +0.88 & +0.56 & -1.47 & \\
\hline & 50 to 59 & 15.6313 & 5.7830 & 2.7615 & 0.0645 & 0.0207 & 1.5662 & \\
\hline & 50 to 59 & +4.24 & +2.62 & -1.93 & -0.34 & -0.19 & -1.36 & \\
\hline & More than & 152.3309 & 209.9936 & 8.1858 & 6.7603 & 30.5486 & 8.7784 & \\
\hline & 60 & +13.28 & +15.83 & -3.33 & -3.50 & -7.19 & +3.22 & \\
\hline
\end{tabular}

Note: PR ${ }^{2}$ - Squared Pearson residual; SPR - Standardized Pearson residual 
Table 5.14 - Squared Pearson residuals $\left(\mathrm{PR}^{2}\right)$, standardized Pearson residuals (SPR) and chi-square $\left(\chi^{2}\right)$ test of independence between the variables of class of the PeCUS index and number of female residents by age range

\begin{tabular}{|c|c|c|c|c|c|c|c|c|}
\hline \multirow{4}{*}{\multicolumn{2}{|c|}{$\begin{array}{l}\text { Female age } \\
\text { range }\end{array}$}} & \multicolumn{6}{|c|}{ Class of $P e C U S$} & \multirow{4}{*}{$\chi^{2}=\sum \mathrm{PR}^{2}$} \\
\hline & & A & B & $\mathrm{C}$ & $\mathrm{D}$ & $\mathrm{E}$ & $\mathrm{F}$ & \\
\hline & & $\mathrm{PR}^{2}$ & $\mathrm{PR}^{2}$ & $\mathrm{PR}^{2}$ & $\mathrm{PR}^{2}$ & $\mathrm{PR}^{2}$ & $\mathrm{PR}^{2}$ & \\
\hline & & SPR & SPR & SPR & SPR & SPR & SPR & \\
\hline \multirow{12}{*}{ 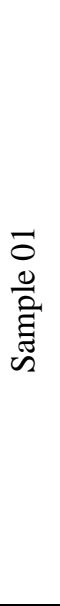 } & \multirow{2}{*}{ Up to 19} & 73.8875 & 15.3145 & 1.6469 & 6.6851 & 54.5348 & 3.3552 & \multirow{12}{*}{$\begin{array}{c}844.7090 \\
\text { p-value }= \\
0.0000 \\
(25 \text { degrees } \\
\text { of freedom })\end{array}$} \\
\hline & & -10.14 & -4.61 & -1.74 & -3.69 & +10.27 & +2.16 & \\
\hline & \multirow{2}{*}{20 to 29} & 15.6468 & 0.0037 & 0.8517 & 0.5958 & 7.0622 & 0.8002 & \\
\hline & & -4.43 & +0.07 & -1.19 & -1.04 & +3.51 & +1.00 & \\
\hline & \multirow{2}{*}{30 to 39} & 14.9543 & 0.7173 & 0.3545 & 4.6669 & 5.3528 & 1.5153 & \\
\hline & & -4.29 & +0.94 & +0.76 & -2.90 & +3.03 & +1.37 & \\
\hline & \multirow{2}{*}{40 to 49} & 5.8717 & 0.0003 & 0.9128 & 3.0665 & 0.0008 & 0.1980 & \\
\hline & & -2.66 & +0.02 & -1.20 & +2.32 & -0.04 & -0.49 & \\
\hline & \multirow{2}{*}{50 to 59} & 4.6462 & 0.4710 & 0.0429 & 8.5816 & 13.4258 & 2.8487 & \\
\hline & & +2.33 & +0.74 & +0.26 & +3.83 & -4.68 & -1.83 & \\
\hline & \multirow{2}{*}{$\begin{array}{l}\text { More than } \\
60\end{array}$} & 419.8737 & 13.2649 & 8.2918 & 4.8379 & 142.7315 & 7.6972 & \\
\hline & & +22.50 & +4.00 & +3.63 & +2.92 & -15.46 & -3.04 & \\
\hline \multirow{12}{*}{ 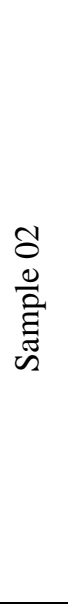 } & \multirow{2}{*}{ Up to 19} & 64.9696 & 47.8639 & 0.0011 & 7.7309 & 54.7619 & 11.5313 & \multirow{12}{*}{$\begin{array}{c}1070.4551 \\
\text { p-value }= \\
0.0000 \\
(25 \text { degrees } \\
\text { of freedom })\end{array}$} \\
\hline & & -9.50 & -8.16 & +0.04 & -4.08 & +10.15 & +3.98 & \\
\hline & \multirow{2}{*}{20 to 29} & 12.5372 & 8.4009 & 0.9784 & 2.2106 & 19.3764 & 2.5572 & \\
\hline & & -3.97 & -3.25 & -1.25 & -2.07 & +5.74 & +1.78 & \\
\hline & \multirow{2}{*}{30 to 39} & 13.1887 & 7.4773 & 6.5595 & 4.4116 & 1.6154 & 11.8788 & \\
\hline & & -4.02 & -3.03 & +3.21 & -2.90 & +1.64 & +3.80 & \\
\hline & \multirow{2}{*}{40 to 49} & 6.5938 & 0.9658 & 0.3551 & 4.4629 & 0.1911 & 0.4919 & \\
\hline & & -2.82 & -1.08 & -0.74 & +2.89 & -0.56 & -0.77 & \\
\hline & \multirow{2}{*}{50 to 59} & 9.9111 & 0.6319 & 1.1926 & 9.4005 & 8.7599 & 10.2106 & \\
\hline & & +3.42 & +0.86 & -1.34 & +4.14 & -3.74 & -3.45 & \\
\hline & \multirow{2}{*}{$\begin{array}{l}\text { More than } \\
60\end{array}$} & 309.8895 & 227.9703 & 0.0006 & 6.5728 & 157.7142 & 37.0898 & \\
\hline & & +19.45 & +16.69 & -0.03 & +3.52 & -16.14 & -6.69 & \\
\hline \multirow{12}{*}{ 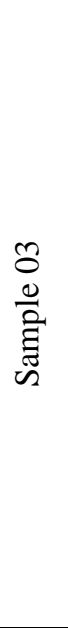 } & \multirow{2}{*}{ Up to 19} & 77.3669 & 91.9794 & 7.1519 & 9.6728 & 6.4328 & 6.0594 & \multirow{12}{*}{$\begin{array}{c}1246.5370 \\
\mathrm{p} \text {-value }= \\
0.0000 \\
(25 \text { degrees } \\
\text { of freedom) }\end{array}$} \\
\hline & & -10.40 & -11.51 & +3.41 & +4.56 & +3.60 & -2.93 & \\
\hline & \multirow{2}{*}{20 to 29} & 15.0530 & 8.7113 & 0.3405 & 0.0112 & 6.1085 & 1.9489 & \\
\hline & & -4.34 & -3.35 & -0.70 & -0.15 & +3.32 & +1.57 & \\
\hline & \multirow{2}{*}{30 to 39} & 13.8508 & 14.5605 & 12.4432 & 1.9515 & 3.3333 & 0.0421 & \\
\hline & & -4.12 & -4.29 & +4.22 & -1.92 & +2.43 & -0.23 & \\
\hline & \multirow{2}{*}{40 to 49} & 5.6030 & 1.3786 & 2.8472 & 4.1249 & 1.4619 & 6.1097 & \\
\hline & & -2.60 & -1.31 & -2.00 & +2.76 & +1.59 & -2.73 & \\
\hline & 50 to 5 & 5.6421 & 3.1498 & 3.4516 & 0.0767 & 0.0823 & 0.2130 & \\
\hline & & +2.57 & +1.95 & -2.17 & +0.37 & -0.37 & -0.50 & \\
\hline & More than & 408.1721 & 388.4165 & 10.9669 & 23.5842 & 80.7261 & 23.5125 & \\
\hline & 60 & +22.19 & +21.98 & -3.92 & -6.61 & -11.84 & +5.37 & \\
\hline
\end{tabular}

Note: $\mathrm{PR}^{2}$ - Squared Pearson residual; SPR - Standardized Pearson residual

Source: The author 
Table 5.15 presents a summary of the excesses and deficits found for each class of the PeCUS index regarding each variable. They also provide information about the positive (+), negative (-) or unclear (+/-) effect of the excess/deficit to the vertical equity, since the effect varies depending on which social group it is related to.

Table 5.15 - Summary of excesses and deficits for each class of the PeCUS index per variable for the three subsamples

\begin{tabular}{|c|c|c|c|c|c|c|c|}
\hline & & \multirow{2}{*}{\multicolumn{6}{|c|}{ Class of $P e C U S$}} \\
\hline & & & & & & & \\
\hline & & A & B & $\mathrm{C}$ & $\mathrm{D}$ & E & $\mathrm{F}$ \\
\hline \multirow{5}{*}{$\begin{array}{c}\text { Range of } \\
\text { monthly } \\
\text { nominal } \\
\text { income }\end{array}$} & $\begin{array}{c}\text { Up to } \\
\mathrm{R} \$ 1,020.00\end{array}$ & Deficit (-) & Deficit (-) & $\mathrm{NR}^{1}$ & Deficit (+/-) & Excess (-) & Excess (-) \\
\hline & $\begin{array}{c}\mathrm{R} \$ 1,020.00 \text { to } \\
\mathrm{R} \$ 2,550.00\end{array}$ & Excess $(+)$ & Excess (+) & $\mathrm{NR}^{1}$ & Excess (+/-) & Deficit (+) & $\mathrm{NR}^{1}$ \\
\hline & $\begin{array}{c}\mathrm{R} \$ 2,550.00 \text { to } \\
\mathrm{R} \$ 5,100.00\end{array}$ & Excess $(+)$ & Excess (+) & $\begin{array}{l}\text { Deficit } \\
(+/-)\end{array}$ & $\mathrm{NR}^{1}$ & Deficit $(+)$ & $\mathrm{NR}^{1}$ \\
\hline & $\begin{array}{c}\mathrm{R} \$ 5,100.00 \text { to } \\
\mathrm{R} \$ 10,200.00\end{array}$ & Excess (-) & Excess (-) & $\begin{array}{l}\text { Deficit } \\
(+/-)\end{array}$ & $\mathrm{NR}^{1}$ & $\mathrm{NR}^{1}$ & $\mathrm{NR}^{1}$ \\
\hline & $\begin{array}{c}\text { More than } \\
\mathrm{R} \$ 10,200.00\end{array}$ & Excess (-) & Excess (-) & $\begin{array}{l}\text { Deficit } \\
(+/-)\end{array}$ & $\mathrm{NR}^{1}$ & $\mathrm{NR}^{1}$ & $\mathrm{NR}^{1}$ \\
\hline \multirow{4}{*}{$\begin{array}{l}\text { Permanent } \\
\text { mobility } \\
\text { constraints }\end{array}$} & Incapacity & $\mathrm{NR}^{1}$ & $\mathrm{NR}^{1}$ & $\mathrm{NR}^{1}$ & $\mathrm{NR}^{1}$ & $\mathrm{NR}^{1}$ & $\mathrm{NR}^{1}$ \\
\hline & Great difficulty & $\mathrm{NR}^{1}$ & $\mathrm{NR}^{1}$ & $\mathrm{NR}^{1}$ & Excess $(+/-)$ & Deficit (+) & $\mathrm{NR}^{1}$ \\
\hline & Some difficulty & Excess $(+)$ & $\mathrm{NR}^{1}$ & $\mathrm{NR}^{1}$ & $\mathrm{NR}^{1}$ & Deficit (+) & $\mathrm{NR}^{1}$ \\
\hline & No disability & Deficit $(+)$ & $\mathrm{NR}^{1}$ & $\mathrm{NR}^{1}$ & Deficit $(+/-)$ & Excess (+) & $\mathrm{NR}^{1}$ \\
\hline \multirow{6}{*}{$\begin{array}{l}\text { Male age } \\
\text { range }\end{array}$} & Up to 19 & Deficit (-) & Deficit (-) & $\mathrm{NR}^{1}$ & $\mathrm{NR}^{1}$ & Excess (-) & $\mathrm{NR}^{1}$ \\
\hline & 20 to 29 & $\mathrm{NR}^{1}$ & $\mathrm{NR}^{1}$ & $\mathrm{NR}^{1}$ & $\mathrm{NR}^{1}$ & $\mathrm{NR}^{1}$ & $\mathrm{NR}^{1}$ \\
\hline & 30 to 39 & Deficit (-) & $\mathrm{NR}^{1}$ & $\mathrm{NR}^{1}$ & $\mathrm{NR}^{1}$ & $\mathrm{NR}^{1}$ & $\mathrm{NR}^{1}$ \\
\hline & 40 to 49 & $\mathrm{NR}^{1}$ & $\mathrm{NR}^{1}$ & $\mathrm{NR}^{1}$ & $\mathrm{NR}^{1}$ & $\mathrm{NR}^{1}$ & $\mathrm{NR}^{1}$ \\
\hline & 50 to 59 & Excess (+) & $\mathrm{NR}^{1}$ & $\mathrm{NR}^{1}$ & $\mathrm{NR}^{1}$ & $\mathrm{NR}^{1}$ & $\mathrm{NR}^{1}$ \\
\hline & More than 60 & Excess (+) & Excess (+) & $\mathrm{NR}^{1}$ & $\mathrm{NR}^{1}$ & Deficit $(+)$ & $\mathrm{NR}^{1}$ \\
\hline \multirow{6}{*}{$\begin{array}{l}\text { Female age } \\
\text { range }\end{array}$} & Up to 19 & Deficit (-) & Deficit (-) & $\mathrm{NR}^{1}$ & $\mathrm{NR}^{1}$ & Excess (-) & $\mathrm{NR}^{1}$ \\
\hline & 20 to 29 & Deficit (-) & $\mathrm{NR}^{1}$ & $\mathrm{NR}^{1}$ & $\mathrm{NR}^{1}$ & Excess (-) & $\mathrm{NR}^{1}$ \\
\hline & 30 to 39 & Deficit (-) & $\mathrm{NR}^{1}$ & $\mathrm{NR}^{1}$ & $\mathrm{NR}^{1}$ & $\mathrm{NR}^{1}$ & $\mathrm{NR}^{1}$ \\
\hline & 40 to 49 & Deficit (-) & $\mathrm{NR}^{1}$ & $\mathrm{NR}^{1}$ & Excess (+/-) & $\mathrm{NR}^{1}$ & $\mathrm{NR}^{1}$ \\
\hline & 50 to 59 & Excess (+) & $\mathrm{NR}^{1}$ & $\mathrm{NR}^{1}$ & $\mathrm{NR}^{1}$ & $\mathrm{NR}^{1}$ & $\mathrm{NR}^{1}$ \\
\hline & More than 60 & Excess (+) & Excess $(+)$ & $\mathrm{NR}^{1}$ & $\mathrm{NR}^{1}$ & Deficit (+) & $\mathrm{NR}^{1}$ \\
\hline
\end{tabular}

1 Not relevant. The standardized Pearson residual has a small contribution to the chi-square $\left(\chi^{2}\right)$ value

(+) Positive effect related to vertical equity in the distribution of the number of residents

$(+/-)$ Unclear effect related to vertical equity in the distribution of the number of residents

(-) Negative effect related to vertical equity in the distribution of the number of residents

Source: The author 
According to Table 5.15, there is a deficit of residents with an income less than $\mathrm{R} \$ 1,020.00$ and an excess of residents with an income greater than $\mathrm{R} \$ 5,100.00$ living near the best quality classes of the PeCUS index (classes A and B). In addition, there is an excess of people with an income less than $\mathrm{R} \$ 1,020.00$ living near the worst quality classes of the PeCUS index (classes $\mathrm{E}$ and F). As, in terms of vertical equity, it is expected that low-income residents will be preferably distributed throughout the best quality classes, the distributions mentioned above represent negative effects to the vertical equity. In contrast, the excess of residents with an income range between $\mathrm{R} \$ 1,020.00$ and $\mathrm{R} \$ 5,100.00$ that live nearby the best classes (A and B) and the deficit of inhabitants from the same income range that live close to one of the worst classes (class E) indicate positive effects to the vertical equity.

Regarding permanent mobility constraints, Table 5.15 shows an excess of people with some difficulty and a deficit of people with no disability living near one of the best classes of the PeCUS index (class A), which indicate positive effects to the vertical equity of residents' distribution. In addition, the deficit of people with great difficulty and some difficulty, and the excess of people with no disability living near one of the worst classes (class E) also indicate positive effects.

Concerning men's age, Table 5.15 points out deficits of men aged up to 19 and between 30 and 39 who live near the best classes of the PeCUS index, and excess of men up to 19 years old who live near one of the worst classes (class E), which represent negative effects to the vertical equity of residents' distribution. On the other hand, the excess of men aged more than 50 living near the best classes and the deficit of men aged more than 60 living near one of the worst classes (class E) indicate positive effects.

Regarding women's age, Table 5.15 presents deficits of women up to 49 years old who live near one of the best classes (class A) of the PeCUS index and excesses of women up to 29 years old that live around one of the worst classes (class E), which indicates negative effects to the vertical equity. In contrast, excesses of women aged more than 50 who live near the best classes and the deficit of women aged more than 60 living near one of the worst classes (class E) indicates positive effects.

\subsection{Summary of the assessment of the community severance caused by transport barriers}

The main results from the assessment of community severance caused by a railway and urban streets are summarized in Table 5.16. 
Table 5.16 - Summary of the main results from the assessment of community severance regarding railway and urban streets (continues)

\begin{tabular}{|c|c|c|c|}
\hline & \multirow{2}{*}{ Railway } & \multirow{2}{*}{ Urban streets } \\
\hline & & & \\
\hline \multirow{4}{*}{ 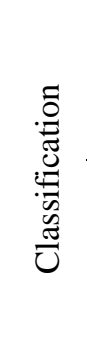 } & \multirow[b]{2}{*}{ Criteria } & \multirow[b]{2}{*}{ scores range from 1 to 3} & scores range from 0 to 1 \\
\hline & & & $\begin{array}{l}\text { the sum of all criteria resulted in the } \\
P e C U S \text { index }\end{array}$ \\
\hline & \multirow[b]{2}{*}{ Scale } & ranges from $\mathrm{A}$ to $\mathrm{D}$ & ranges from $\mathrm{A}$ to $\mathrm{F}$ \\
\hline & & $\begin{array}{l}\text { the higher the quality of the pedestrian } \\
\text { crossing the lower the severity of the barrier } \\
\text { effect }\end{array}$ & $\begin{array}{l}\text { the higher the quality of the pedestrian } \\
\text { crossing the lower the severity of the } \\
\text { barrier effect }\end{array}$ \\
\hline \multirow{4}{*}{ 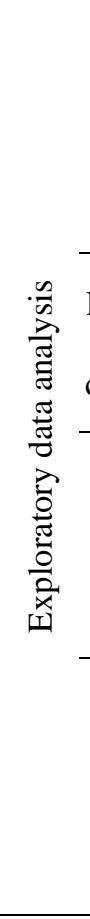 } & Income & $\begin{array}{l}\text { Classes A and B have the higher portions of } \\
\text { residents with income over R } \$ 10,200.00 \text {, } \\
\text { while classes C and D have residents } \\
\text { predominantly with incomes lower than } \\
\mathrm{R} \$ 1,020.00\end{array}$ & $\begin{array}{l}\text { The population with an income greater } \\
\text { than } \mathrm{R} \$ 5,100.00 \text { that lives near classes } \mathrm{A} \\
\text { and } \mathrm{B} \text { is about twice as large as the portion } \\
\text { that lives in other classes. More than half } \\
\text { of the residents in classes } \mathrm{C}, \mathrm{D}, \mathrm{E} \text { and } \mathrm{F} \\
\text { have a monthly income below } \mathrm{R} \$ 1,020.00\end{array}$ \\
\hline & $\begin{array}{l}\text { Permanent } \\
\text { mobility } \\
\text { constraints }\end{array}$ & $\begin{array}{l}\text { Population distribution is similar for all } \\
\text { social groups, except for the self-declared } \\
\text { incapable residents whose distribution is } \\
\text { significant around class B }\end{array}$ & $\begin{array}{l}\text { The proportion of residents with some } \\
\text { difficulty is higher among the residents that } \\
\text { live near class A }\end{array}$ \\
\hline & Gender & $\begin{array}{l}\text { The number of women is proportionally } \\
\text { higher surrounding class A, while in the } \\
\text { other classes B and C there is a slightly } \\
\text { higher distribution for female and in class D, } \\
\text { the gender distribution is balanced }\end{array}$ & \multirow{2}{*}{$\begin{array}{l}\text { The majority of the population (male and } \\
\text { female) that lives near class A streets are } \\
\text { over } 60 \text { years old, and this proportion is } \\
\text { higher among women (about } 1 / 3 \text { ) than } \\
\text { among men (about } 1 / 4 \text { ). }\end{array}$} \\
\hline & $\begin{array}{l}\text { Age } \\
\text { range }\end{array}$ & $\begin{array}{l}\text { The distribution of residents who live close } \\
\text { to class A and B railroad crossings is slightly } \\
\text { higher for the residents aged over } 60 \text { years } \\
\text { old. While in classes C and D, the age ranges } \\
\text { from } 20 \text { to } 29 \text { years old are slightly greater } \\
\text { than the other age ranges }\end{array}$ & \\
\hline & 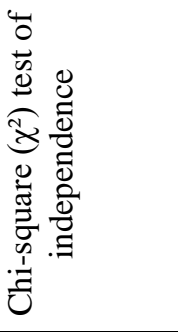 & $\begin{array}{l}\text { Evidence of association between the } \\
\text { variables classification and: (i) number of } \\
\text { residents by range of monthly nominal } \\
\text { income, (ii) number of residents with self- } \\
\text { declared permanent mobility constraints, } \\
\text { (iii) number of residents by gender and (iv) } \\
\text { number of residents by age range. }\end{array}$ & $\begin{array}{l}\text { Evidence of association between the } \\
\text { variables classification and: }(i) \text { number of } \\
\text { residents by range of monthly nominal } \\
\text { income, (ii) number of residents with self- } \\
\text { declared permanent mobility constraints, } \\
\text { (iii) number of female residents by age } \\
\text { range and (iv) number of male residents by } \\
\text { age range. }\end{array}$ \\
\hline \multirow{2}{*}{ 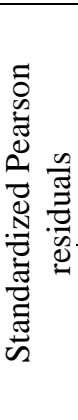 } & Income & $\begin{array}{l}\text { There is an excess of residents with an } \\
\text { income greater than } R \$ 5,100.00 \text { that live } \\
\text { near class B and an excess of residents with } \\
\text { income less than } R \$ 1,020.00 \text { who lives near } \\
\text { classes C and D }\end{array}$ & $\begin{array}{l}\text { There is an excess of residents with an } \\
\text { income greater than } \mathrm{R} \$ 5,100.00 \text { living } \\
\text { near classes A and B. In addition, there is } \\
\text { an excess of people with an income greater } \\
\text { than } \mathrm{R} \$ 1,020.00 \text { living near the classes E } \\
\text { and F }\end{array}$ \\
\hline & $\begin{array}{l}\text { Permanent } \\
\text { mobility } \\
\text { constraints }\end{array}$ & $\begin{array}{l}\text { There is an excess of residents with some } \\
\text { difficulty that live near class A }\end{array}$ & $\begin{array}{l}\text { There is an excess of people with some } \\
\text { difficulty living near class A, a deficit of } \\
\text { people with great difficulty and some } \\
\text { difficulty living near class E }\end{array}$ \\
\hline
\end{tabular}


Table 5.16 - Summary of the main results from the assessment of community severance regarding railway and urban streets (conclusion)

\begin{tabular}{|c|c|c|c|}
\hline \multirow{2}{*}{ 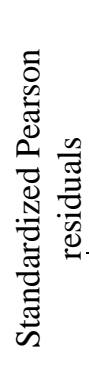 } & Gender & $\begin{array}{l}\text { There is deficit of women who live around } \\
\text { classes A and C, while there is an excess of } \\
\text { women living near classes B and D. } \\
\text { Inversely, for men there is an excess living } \\
\text { near classes A and C, whereas there is a } \\
\text { deficit living around classes B and D }\end{array}$ & \multirow{2}{*}{$\begin{array}{l}\text { There is an excess of men up to } 19 \text { years old } \\
\text { who live near class E, an excess of men aged } \\
\text { more than } 60 \text { living near classes A and B. } \\
\text { There are deficits of women up to } 49 \text { years } \\
\text { old who live near the class A, and excesses } \\
\text { of women up to } 29 \text { years old that live around } \\
\text { class E. In contrast, there are excesses of } \\
\text { women aged more than } 50 \text { who live near } \\
\text { class A }\end{array}$} \\
\hline & $\begin{array}{l}\text { Age } \\
\text { range }\end{array}$ & $\begin{array}{l}\text { There is a deficit of residents aged up to } 19 \\
\text { in classes A and B, an excess of residents } \\
\text { aged more than } 60 \text { around classes A and B }\end{array}$ & \\
\hline \multirow{4}{*}{ 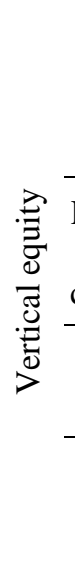 } & Income & $\begin{array}{l}\text { The distribution of residents concerning } \\
\text { income is vertically equitable, except for } \\
\text { residents with income less than } R \$ 1,020.00 \\
\text { and more than } R \$ 5.100 .00\end{array}$ & $\begin{array}{l}\text { The distribution of residents concerning } \\
\text { income is vertically equitable, except for } \\
\text { residents with income less than } R \$ 1,020.00 \\
\text { and more than } R \$ 5.100 .00\end{array}$ \\
\hline & $\begin{array}{l}\text { Permanent } \\
\text { mobility } \\
\text { constraints }\end{array}$ & $\begin{array}{l}\text { The distribution of residents with permanent } \\
\text { mobility constraints is vertically equitable }\end{array}$ & $\begin{array}{l}\text { The distribution of residents with permanent } \\
\text { mobility constraints is vertically equitable }\end{array}$ \\
\hline & Gender & $\begin{array}{l}\text { The distribution of female or male residents } \\
\text { is vertically equitable }\end{array}$ & \multirow{2}{*}{$\begin{array}{l}\text { The distribution of male or female residents } \\
\text { is vertically equitable for residents aged } \\
\text { more than } 50 \text { years old. In contrast, for the } \\
\text { other female or male age ranges, the } \\
\text { distribution is not vertically equitable }\end{array}$} \\
\hline & $\begin{array}{l}\text { Age } \\
\text { range }\end{array}$ & $\begin{array}{l}\text { The distribution of residents regarding age is } \\
\text { vertically equitable, except for residents aged } \\
\text { up to } 19 \text { years }\end{array}$ & \\
\hline
\end{tabular}

Source: The author

As presented in Table 5.16, the classification criteria and scale from the railway and urban streets were suitable for the different transport infrastructures. Therefore, in the case of the urban streets, in which their similar characteristics allowed a unified evaluation, the creation of an index (PeCUS index) was possible.

The exploratory data analysis for both infrastructures had similar results, while the results from the chi-square $\left(\chi^{2}\right)$ test of independence were the same. On the other hand, the standardized Pearson residual results for gender slightly diverged, while for the other variables they were similar. Finally, regarding the vertical equity, the results for gender and age differed slightly, while for the other variables they were the same. 


\section{CONCLUSIONS}

This study presented a simple and low-cost analytical approach for the assessment of community severance based on the classification of the quality of pedestrian crossings on two different types of transport infrastructures of a medium-sized city: railway and urban streets. The quality of the railroad crossings was based in the evaluation of a set criteria suitable for each type of railroad crossing. On the other hand, the quality of Pedestrian Crossings on Urban Streets (PeCUS) was performed through an index. The PeCUS index was used to identify variations in the quality of crossings in a random sample $\left(\mathrm{n}_{0}=100\right)$ of urban streets. Additionally, the approach was used to identify possible inequities in the surroundings of the distinct classification groups for both transport infrastructures. This can be seen as an indirect assessment of community severance.

The analysis of the chi-square $\left(\chi^{2}\right)$ tests of independence and the standardized Pearson residuals carried out in the area of influence of the railroad crossings, segments without railroad crossings and the urban streets subsamples $\left(\mathrm{n}_{1}=38, \mathrm{n}_{2}=35\right.$ e $\left.\mathrm{n}_{3}=37\right)$, suggested an association between the variables of classification and the demographic characteristics studied. Furthermore, the standardized Pearson residuals were also used to indicate deficits and excesses of residents regarding monthly nominal income, permanent mobility constraints, gender and age surrounding the railway and the urban streets. Additionally, it pointed out that the conditions for pedestrian urban mobility of some population strata may be impaired.

Concerning the railway, the study found evidence that low-income (less than $\mathrm{R} \$ 1,020.00$ ) residents tend to live around the worst classes of crossings and segments without crossings, while high-income (greater than $\mathrm{R} \$ 5,100.00$ ) inhabitants tend to live around one of the best classes. Residents with some difficulty in walking or climbing stairs tend to live near the best class crossings, men or women tend to live near the best classes. Residents aged up to 19 tend not to live in the surroundings where the best classes are, and residents aged more than 60 tend to live near the best classes. Particularly, the population who live near the segments without railroad crossings (class D) are prone to traveling longer distances in order to transpose the railway. This could be an indicative that this population is more susceptible to active trip diversion or suppression, thus their health and well-being condition could tend to be more affected.

In relation to the urban streets, we found evidence that residents with an income over $\mathrm{R} \$ 1,020.00$, have some difficulty in walking or climbing stairs, or are over 50 years old tend 
to live near the best quality of $P e C U S$ index. In contrast, residents with an income less than $\mathrm{R} \$ 1,020.00$, no disability or aged up to 19 tend to live near the worst quality of $P e C U S$ index.

In summary, the inhabitants that live in the railway surroundings and have a high income, have permanent mobility constraints, are men or women, or are aged above 60 years old are well assisted in relation to pedestrian urban mobility. Moreover, residents that have a low income or are aged up to 19 years old are poorly assisted in relation to pedestrian urban mobility. In addition, the inhabitants nearby the urban streets that have an income higher than $\mathrm{R} \$ 1,020.00$, permanent mobility constraints or are aged above 50 years old are well assisted in relation to pedestrian urban mobility. Moreover, low-income residents (nearby urban streets) or aged up to 19 are poorly assisted in relation to pedestrian urban mobility conditions.

Hence, even with the limitation of aggregated data, the research responds to the questions formulated in Chapter 1, indicating that the assessment of community severance by the analysis of the quality of pedestrian crossings on railways and urban streets is feasible. In addition, the study proposed an index capable of estimating the quality of pedestrian crossings on urban streets, the PeCUS index. Furthermore, the study shows evidence of an association between the distribution of residents with distinct demographic characteristics around transport barriers and the quality of pedestrian crossings. Moreover, it also highlights that the distribution of the number of residents surrounding the distinct classes of railroad crossings and segments without railroad crossings is vertically equitable for vulnerable social groups, except for residents with a low income and aged up to 19 years old. Besides that, the distribution of the number of residents surrounding the distinct classes of the PeCUS index is vertically equitable for vulnerable social groups (e.g. residents with permanent mobility constraints and elderly), except for low-income residents and for male/female residents aged up to 19 years old. 


\section{RECOMMENDATIONS}

Particularly in Brazil, the analysis of the community severance caused by transport infrastructures still requires more detailed studies. The main contributions of this study include the methodology developed and tested, and the index of quality of Pedestrian Crossings on Urban Streets (the PeCUS index) created and tested here as well.

This study showed evidence that the community severance caused by different transport infrastructures has a distribution of the number of residents surrounding the distinct classes of quality of pedestrian crossings, substantially similar. This could be a consequence of the aggregated data used.

For further research, we recommend incorporating the land use criterion for railway assessment. We also suggest using this study in other medium-sized cities and comparing the results in order to identify patterns regarding the different classes of quality of pedestrian facilities to transpose transport barriers and the demographic characteristics of its surrounding population. In addition, we recommend using disaggregated data for the analysis, which could be collected through questionnaires or interviews. Using disaggregated data helps to capture the perception of residents living in the transport barriers surroundings and track the variability of the distribution of the population. The analysis of residents' perceptions could be an important contribution, because it may identify the suppression of trips by active modes, impacts on social interactions and impacts on the well-being of the inhabitants, which are also important factors to characterize community severance. 
ABNT. (2009). NBR 15680: Via férrea - Travessia rodoviária - Passagem em nível pública Requisitos de projetos. Associação Brasileira de Normas Técnicas: ABNT, Rio de Janeiro, Brazil.

ABNT. (2015). NBR 9050: Acessibilidade a edificações, mobiliário, espaços e equipamentos urbanos. Associação Brasileira de Normas Técnicas: ABNT, Rio de Janeiro, Brazil.

Agresti, A. (2018). An introduction to categorical data analysis (3rd ed.). John Wiley \& Sons.

Anciaes, P. R. (2013). Measuring community severance for transport policy and project appraisal. WIT Transactions on the Built Environment, 130, 559-569. https://doi.org/10.2495/UT130451

Anciaes, Paulo Rui. (2015). What do we mean by "community severance”? (Street mobility and network accessibility series No. 4). London, United Kingdom.

Anciaes, Paulo Rui, Boniface, S., Dhanani, A., Mindell, J. S., \& Groce, N. (2016). Urban transport and community severance: Linking research and policy to link people and places. Journal of Transport and Health, 3(3), 268-277. https://doi.org/10.1016/j.jth.2016.07.006

Anciaes, Paulo Rui, Jones, P., \& Metcalfe, P. J. (2018). A stated preference model to value reductions in community severance caused by roads. Transport Policy, 64, 10-19. https://doi.org/10.1016/j.tranpol.2018.01.007

Anciaes, Paulo Rui, Jones, P., \& Mindell, J. S. (2016). Community severance: Where is it found and at what Cost? Transport Reviews, 36(3), 293-317. https://doi.org/10.1080/01441647.2015.1077286

Anciaes, Paulo Rui, Jones, P., \& Mindell, J. S. (2017). Quantifying the barrier effect of main roads on pedestrian preferences and behavior. Transportation Research Board, 96th Annual Meeting, 44, 16. Retrieved from http://amonline.trb.org/63532-trb1.3393340/t017-1.3406062/889-1.3406063/17-02424-1.3406066/17-02424$1.3406067 ? \mathrm{qr}=1$

Anciaes, Paulo Rui, Stockton, J., Ortegon, A., \& Scholes, S. (2019). Perceptions of road traffic conditions along with their reported impacts on walking are associated with wellbeing. Travel Behaviour and Society, 15, 88-101. https://doi.org/10.1016/j.tbs.2019.01.006

Appleyard, D., \& Lintell, M. (1972). The environmental quality of city streets: The residents' viewpoint. Journal of the American Institute of Planners, 38(2), 84-101. https://doi.org/10.1080/01944367208977410

Bereitschaft, B. (2017). Equity in microscale urban design and walkability: A photographic survey of six Pittsburgh streetscapes. Sustainability, 9(7), 1-20. https://doi.org/10.3390/su9071233

Burton, E., \& Mitchell, L. (2006). Inclusive urban design: Streets for life. Oxford, United Kingdom: Architectural Press.

${ }^{1}$ According to the American Psychological Association (APA) style. 
Cantillo, V., Arellana, J., \& Rolong, M. (2015). Modelling pedestrian crossing behaviour in urban roads: A latent variable approach. Transportation Research Part F: Traffic Psychology and Behaviour, 32, 56-67. https://doi.org/10.1016/j.trf.2015.04.008

Chang, J. S., Han, S., Jung, D., \& Kim, D. (2014). Benefits of rerouting railways to tunnels in urban areas: A case study of the Yongsan line in Seoul. International Journal of Urban Sciences, 18(3), 404-415. https://doi.org/10.1080/12265934.2014.934270

Curie, M. (1922, January). The story of my life. The Delineator, (99), 4-5.

Davis, A., \& Jones, L. (1997). Whose neighbourhood? Whose quality of life? Developing a new agenda for children's health in urban settings. Health Education Journal, 56(4), 350363. https://doi.org/10.1177/001789699705600404

DNIT. (2010). Manual de projeto geométrico de travessias urbanas. Departamento Nacional de Infraestrutura de Transportes: DNIT, Rio de Janeiro, Brazil. Retrieved from http://ipr.dnit.gov.br/normas-e-

manuais/manuais/documentos/740_manual_projetos_geometricos_travessias_urbanas.pd $\mathrm{f}$

DNIT. (2015a). ISF-216: Projeto de obras de arte especiais. Departamento Nacional de Infraestrutura de Transportes: DNIT, Rio de Janeiro, Brazil.

DNIT. (2015b). ISF-217: Projeto de sinalização ferroviária. Departamento Nacional de Infraestrutura de Transportes: DNIT, Rio de Janeiro, Brazil.

DNIT. (2015c). ISF-219: Projeto de passarela para pedestres. Departamento Nacional de Infraestrutura de Transportes: DNIT, Rio de Janeiro, Brazil.

DNIT. (2015d). ISF-221: Projeto de passagem em nível. Departamento Nacional de Infraestrutura de Transportes: DNIT, Rio de Janeiro, Brazil.

DNIT. (2015e). ISF-223: Projeto de passagem inferior. Departamento Nacional de Infraestrutura de Transportes: DNIT, Rio de Janeiro, Brazil.

Foley, L., Prins, R., Crawford, F., Humphreys, D., Mitchell, R., Sahlqvist, S., ... Ogilvie, D. (2017). Effects of living near an urban motorway on the wellbeing of local residents in deprived areas: Natural experimental study. PLoS ONE, 12(4), 1-16. https://doi.org/10.1371/journal.pone.0174882

Guo, X., Black, J., \& Dunne, M. (2001). Crossing pedestrians and dynamic severance on urban main roads. Road and Transport Research, 10(3), 84-98.

Hair, J. F., Black, W. C., Babin, B. J., \& Anderson, R. E. (2010). Multivariate Data Analysis (7th ed.). Prentice Hall. from https://books.google.com.br/books?id=JlRaAAAAYAAJ

Hart, J., \& Parkhurst, G. (2011). Driven to excess: Impacts of motor vehicles on the quality of life in of residents of three streets in Bristol UK. World Transport Policy Practice, 17(2), 12-30. $\quad$ Retrieved

from http://trid.trb.org/view.aspx?id=886453\%5Cnhttp://eprints.uwe.ac.uk/15513/ 
Hine, J. (1996). Pedestrian travel experiences - Assessing the impact of traffic on behaviour and perceptions of safety using an in-depth interview technique. Journal of Transport Geography, 4(3), 179-199. https://doi.org/10.1016/0966-6923(96)00003-8

Hine, J., \& Russell, J. (1993). Traffic barriers and pedestrian crossing behaviour. Journal of Transport Geography, 1(4), 230-239. https://doi.org/10.1016/0966-6923(93)90047-4

IBGE. (2010). Censo demográfico 2010. Instituto Brasileiro de Geografia e Estatística: IBGE, Rio de Janeiro, Brazil. Retrieved from https://sidra.ibge.gov.br/pesquisa/censodemografico/demografico-2010/inicial

IBGE. (2016). Grade estatística. Instituto Brasileiro de Geografia e Estatística: IBGE, Rio de Janeiro, Brazil.

Jang, S., An, Y., Yi, C., \& Lee, S. (2017). Assessing the spatial equity of Seoul's public transportation using the Gini coefficient based on its accessibility. International Journal of Urban Sciences, 21(1), 91-107. https://doi.org/10.1080/12265934.2016.1235487

Kelobonye, K., McCarney, G., Xia, J. (Cecilia), Swapan, M. S. H., Mao, F., \& Zhou, H. (2019). Relative accessibility analysis for key land uses: A spatial equity perspective. Journal of Transport Geography, 75, 82-93. https://doi.org/10.1016/j.jtrangeo.2019.01.015

Lara, D. V. R., \& Rodrigues da Silva, A. N. (2018). Questões de equidade associadas a barreiras de transportes em uma cidade média. In 32nd Congresso de Pesquisa e Ensino em Transportes da ANPET (pp. 459-470). Gramado, Brazil. Retrieved from http://146.164.5.73:30080/tempsite/anais/documentos/2018/Aspectos Economicos Sociais Politicos e Ambientais do Transporte/Transporte e Inclusao Social/3_437_AC.pdf

Lee, J., \& Sohn, K. (2014). Identifying the Impact on Land Prices of Replacing At-grade or Elevated Railways with Underground Subways in the Seoul Metropolitan Area. Urban Studies, 51(1), 44-62. https://doi.org/10.1177/0042098013484543

Litman, T. (2002). Evaluating transportation equity: Guidance for incorporating distributional impacts in transportation planning. World Transport Policy \& Practice, 8(2), 50-65. https://doi.org/www.vtpi.org/equity.pdf

Mackett, R. L., \& Thoreau, R. (2015). Transport, social exclusion and health. Journal of Transport and Health, 2(4), 610-617. https://doi.org/10.1016/j.jth.2015.07.006

McPherson, C., \& Daff, M. (2005). Pedestrian behaviour and the design of accessible rail crossings. In 28th Australasian Transport Research Forum (ATRF) (pp. 1-15). Sydney, Australia.

Mindell, J. S., Anciaes, P. R., Dhanani, A., Stockton, J., Jones, P., Haklay, M., ... Vaughan, L. (2017). Using triangulation to assess a suite of tools to measure community severance. $\begin{array}{llll}\text { Journal of Transport Geography, } & 60, & 119-129 .\end{array}$ https://doi.org/10.1016/j.jtrangeo.2017.02.013

Ministry of Cities. (2007). PlanMob - Caderno de referência para elaboração de Plano de Mobilidade Urbana. Brasília, Brazil.

Mouette, D., Aidar, T., \& Waisman, J. (2000). Avaliação dos impactos do tráfego na mobilidade 
da população infantil através da análise de correspondência múltipla. Revista Transportes, 8(1), 56-87. https://doi.org/10.14295/transportes.v8i1.198

Mouette, D., \& Waisman, J. (2004). Proposta de uma metodologia de avaliação do efeito barreira. Revista Dos Transportes Públicos - ANTP, 26(2 Trimestre), 33-54.

Nimegeer, A., Thomson, H., Foley, L., Hilton, S., Crawford, F., \& Ogilvie, D. (2018). Experiences of connectivity and severance in the wake of a new motorway: Implications for health and well-being. Social Science and Medicine, 197, 78-86. https://doi.org/10.1016/j.socscimed.2017.11.049

Okabe, A., Boots, B., Sugihara, K., \& Chiu, S. N. (2009). Spatial Tessellations: Concepts and applications of Voronoi diagrams. (2, Ed.). John Wiley \& Sons.

Pereira, R. H. M. (2018). Transport legacy of mega-events and the redistribution of accessibility to urban destinations. Cities, 81, 45-60. https://doi.org/10.1016/j.cities.2018.03.013

Pereira, R. H. M., Schwanen, T., \& Banister, D. (2017). Distributive justice and equity in transportation. Transport Reviews, 37(2), 170-191. https://doi.org/10.1080/01441647.2016.1257660

Rajé, F. (2004). Engineering social exclusion? Poor transport links and severance. In Proceedings of the Institution of Civil Engineers (Vol. 157, pp. 267-273). https://doi.org/10.1680/muen.2004.157.4.267

Rosenlieb, E. G., McAndrews, C., Marshall, W. E., \& Troy, A. (2018). Urban development patterns and exposure to hazardous and protective traffic environments. Journal of Transport Geography, 66, 125-134. https://doi.org/10.1016/j.jtrangeo.2017.11.014

Scholes, S., Boniface, S., Stockton, J., \& Mindell, J. (2016). Developing a questionnaire to assess community severance, walkability, and wellbeing: results from the Street Mobility Project in London (Street mobility and network accessibility series No. 5). London, United Kingdom. Retrieved from http://discovery.ucl.ac.uk/1474883/

Shirmohammadli, A., Louen, C., \& Vallée, D. (2016). Exploring mobility equity in a society undergoing changes in travel behavior: A case study of Aachen, Germany. Transport Policy, 46, 32-39. https://doi.org/10.1016/j.tranpol.2015.11.006

Silva Jr, S. B. da, \& Ferreira, M. A. G. (2008). Rodovias em áreas urbanizadas e seus impactos na percepção dos pedestres. Sociedade \& Natureza, 20(1), 221-237. https://doi.org/10.1590/S1982-45132008000100015

Sisiopiku, V. P., \& Akin, D. (2003). Pedestrian behaviors at and perceptions towards various pedestrian facilities: An examination based on observation and survey data. Transportation Research Part F: Traffic Psychology and Behaviour, 6(4), 249-274. https://doi.org/10.1016/j.trf.2003.06.001

Soguel, N. C. (1995). Costing the traffic barrier effect: A contingent valuation survey. Environmental \& Resource Economics, 6(3), 301-308. https://doi.org/10.1007/BF00705983

Sousa, J. R., Sousa, M. T. R. de, \& Braga, R. (2009). Os problemas da mobilidade urbana na 
periferia brasileira: o caso do município De Rio Claro/SP. Revista Da Casa Da Geografia de Sobral, 11(1), 61-69. Retrieved from www.uvanet.br/rcgs

Taylor, J., \& Crawford, R. (2009). Prioritising road-rail level crossings for grade separation using a multi-criteria approach. In 32nd Australasian Transport Research Forum (ATRF) (p. 15). Auckland, New Zealand. Retrieved from http://atrf.info/papers/2009/2009_Taylor_Crawford.pdf

Timperio, A., Ball, K., Salmon, J., Roberts, R., Giles-Corti, B., Simmons, D., ... Crawford, D. (2006). Personal, family, social, and environmental correlates of active commuting to school. American Journal of Preventive Medicine, 30(1), 45-51. https://doi.org/10.1016/j.amepre.2005.08.047

Transportation Research Board. (2010). HCM 2010: Highway capacity manual. Washington, D.C.: Transportation Research Board, National Research Council.

Tsou, K.-W., Hung, Y.-T., \& Chang, Y.-L. (2005). An accessibility-based integrated measure of relative spatial equity in urban public facilities. Cities, 22(6), 424-435. https://doi.org/10.1016/j.cities.2005.07.004

Woodcock, A. (2018). Supporting urban integrated transport systems. WPR 7: Social impact assessment report. United Kingdom.

Vasconcellos, E. A. de. (2016). Mobilidade cotidiana, segregação urbana e exclusão. In Cidade e movimento: mobilidades e interações no desenvolvimento urbano ( $1^{\text {st }}$ ed., pp. 57-79). Brasília: IPEA. Retrieved from http://www.ipea.gov.br 